\title{
MATERIALES PARA EL ESTUDIO DE LA EDAD DEL BRONCE EN EL VALLE MEDIO DEL VINALOPO (ALICANTE)
}

\author{
JUAN FRANCISCO NAVARRO MEDEROS \\ Universidad de La Laguna
}

\begin{abstract}
Se presenta un grupo de poblados del Bronce en el Valle Medio del Vinalopó, provincia de Alicante, y los materiales procedentes de ellos y conservados en colecciones privadas. Su conocimiento permite incluir esta comarca en la cultura del Bronce Valenciano - aunque manteniendo una cierta personalidad-y aventurar hipótesis sobre la dinámica de la Edad del Bronce a lo largo de la cuenca del Vinalopó, sus contactos exteriores, las fronteras con el mundo argárico e intentar ordenarlos cronológicamente en base a un esquema propuesto para la globalidad del Bronce Valenciano.

L'article offre l'étude d'un groupe de sites de l'âge du Bronze dans la vallée du Vinalopó et des matériaux archéologiques conservés dans des collections privées. Des resultats de cet étude on peut inférer l'appartenance de cette zone a la civilisation du Bronce Valenciano, tout en conservant des traits individuants, et aussi tenter d'expliquer la dynamique de l'âge du Bronze au long de la vallée du Vinalopó, ses rapports extérieurs et la frontière avec la civilisation de l'Argar. On donne également une tentative de chronologie fondée sur un schéma global pour le Bronze Valenciano.
\end{abstract}

\section{INTRODUCCION}

Una vieja polémica gira en torno al problema de los límites del Bronce Valenciano y su frontera con el mundo argárico, la cual se ha situado indistintamente en el Vinalopó y en el Segura, si bien en ambos casos tal suposición carecía del sostén documental necesario, ya que ni en la zona que hay entre ambos ríos ni en gran parte de la cuenca del Vinalopó se conocían yacimientos. Especialmente en su Valle Medio, comarca que se encontraba desprovista aparentemente de vestigios del Bronce, mientras que en el Valle Alto existía un nutrido grupo de poblados estudiados por J. M. Soler García y que se venían incluyendo en el Bronce Argárico; así como en la Vega Baja del Segura, donde desde principios de siglo se conocían ampliamente los poblados argáricos de Callosa y Orihuela y, más recientemente, algunos en el Valle Bajo del Vinalopó como el Pic de les Moreres (Crevillente) y el Puntal del Búho (Elche) (J. L. ROMAN LAJARIN: 1975 y 1978).

Interesados en el problema, decidimos realizar prospecciones por el Valle Medio y tierras aledañas, iniciándolas en 1976, pero sobre todo entre 1977 y 1979. Desde antes ya teníamos conocimiento de que había en Novelda varios aficionados y dos grupos de «Operación Rescate» (del Colegio Padre Dehón, PP. Reparadores), con cuyo profesor-jefe, el padre Vicente Gómez, entramos pronto en contacto, dándonos a conocer la existencia de varios yacimientos y facilitándonos el acceso a algunas colecciones particulares, entre ellas la suya propia.

De esta manera podemos presentar hoy aquí catorce poblados - la mayoría de ellos dados a conocer ya en un breve artículo (GRUPO DE RESCATE 688: 1978) - y los materiales procedentes de los mismos que obran en las siguientes colecciones privadas de Novelda: colección de don Manuel Romero Iñesta (una parte de ella se expone actualmente en el Museo Arqueológico Municipal), co- 
lección «Rescate» del Colegio Padre Dehón, colección «Museo Didáctico» (propiedad de don Vicente Gómez García, en dicho colegio) y colección de don Antonio Alberola, a quienes agradecemos su amable colaboración. Existen, además, otras colecciones a las que no tuvimos acceso, aunque poseemos noticias de que el grueso de sus materiales no corresponde al período que nos ocupa.

El ámbito geográfico que hemos abarcado incluye todo el Valle Medio del Vinalopó, exceptuando el valle de Elda-Petrel, que dejamos fuera porque sus yacimientos y materiales del Bronce ya han sido dados a conocer (CENTRO EXCURSIONISTA ELDENSE: 1972) y actualmente son objeto de una Memoria de Licenciatura. Por lo tanto, nos ceñimos a los términos municipales de Aspe, Monforte del Cid, Novelda y Monóvar que forman una unidad geográfica precisa.

\section{EL AZUD}

A unos $700 \mathrm{~m}$. al WSW. de Monforte del Cid (Alicante) el cauce del río Vinalopó se estrecha en una pequeña garganta flanqueada por dos promontorios. El río en este punto sirve de límite entre los términos de Novelda y el citado Monforte del Cid (Alicante). Coordenadas geográficas: $38^{\circ} 22^{\prime} 50^{\prime \prime}$ lat. N. y $0^{\circ} 44^{\prime} 25$ ' long. W. del meridiano de Greenwich.

Esta estrechez del cauce fue aprovechada para la construcción de un azud o noria de agua en época árabe, estando actualmente cegada la pequeña presa y no quedando del azud más que unas ruinas.

Sobre ambos promontorios, cortados a pico por el río, hay restos de poblado de la Edad del Bronce, prospectados por los Grupos de Rescate 688 y 689 (Gómez García, V.: 1976, p. 11) El que se levanta sobre la margen derecha tiene su base socavada por el río y en su pequeña cima hay manchas de cenizas y cerámicas, así como un molino naviforme. El de la margen izquierda contiene un yacimiento extenso con abundantes fragmentos de cerámica, un gran molino naviforme y trozos de otros. Sin embargo, el relleno arqueológico es muy escaso.

\section{CASA PAUS}

En las estribaciones meridionales del Montagut y a unos $2 \mathrm{Km}$. en la línea recta del río Vinalopó, en el término municipal de Novelda (Alicante) existe una pequeña elevación de suaves laderas y escasa altura. Recibe el nombre de la finca a la que pertenece, aunque también es conocido recientemente como «El Trial», por una pista de moto-cross que se ha creado en tal sitio. Coordenadas geográficas: $38^{\circ} 24^{\prime} 50^{\prime}$ ' lat. N. y $0^{\circ} 45^{\prime} 57^{\prime}$ ' long. W. del meridiano de Greenwich.

Prospectado con anterioridad, fue excavado en 1976 por el Grupo de Rescate 688 , ante el peligro de ser destruido por la citada pista de moto-cross. Nosotros lo visitamos en 1977, observando los restos de la excavación, que había puesto al descubrimiento tres muros casi paralelos, pero muy mal conservados, que darían lugar a dos viviendas rectangulares; las viviendas estaban situadas en la parte alta de la ladera Sur, resguardada de los vientos del Norte por las rocas de la cima. 
Superficialmente había fragmentos de cerámica basta y otros de pasta más cuidada, así como gran cantidad de caracoles terrestres (Iberus alonensis) mezclados con las cenizas.

La Colección Rescate del Colegio Padre Dehón tiene de este yacimiento un vaso semielíptico de pasta poco cuidada, desgrasantes irregulares, color gris oscuro y superficie rugosa $(13 \mathrm{cms}$. de diámetro, $11 \mathrm{cms}$. de altura) (fig. 1, a); fragmento de cuenco semiesférico de finas paredes y otro de vaso globular con borde exvasado, ambos de pasta poco cuidada, color negruzco, abundantes desgrasantes y superficie espatulada; un tercio de vasija de fondo convexo, pasta regular, numerosos desgrasantes de pequeño calibre, color rojizo y superficie espatulada. De sílex melado con pátina blanca hay: una punta de flecha romboidal muy erosionada (fig. 1, b); otra punta de flecha de base cóncava (fig. 1, c); varias lascas y hojas sin retoques, algunas con reserva y otras desecho de talla; tres lascas con retoques de uso; fragmento de diente de hoz.

En la colección de M. Romero Iñiesta hay cuatro fragmentos de cerámica muy erosionada - uno de ellos perteneciente a una vasija carenada de mediano tamaño-, las pastas son regulares y de color marrón-rojizo al negro; parte de un cuenco semiesférico de unos $23 \mathrm{cms}$. de diámetro, paredes finas, dos mamelones gemelos puntiagudos a $2 \mathrm{cms}$. del borde, color negruzco y superficie pulimentada. Hay sesenta y seis láminas y lascas de sílex melado, algunas blancas y dos o.tres de sílex rojo, la mayoría sin retoques, aunque algunas láminas presentan retoques de uso; seis dientes de hoz. Un fragmento del extremo de un brazalete de arquero, de pizarra, con un orificio bitroncocónico. De metal -cobre o bronce- hay una especie de lezna de sección cuadrada y filo en bisel de 7' 1 x 0'8 cms.

En cuanto a la fauna, hay que mencionar en la Colección Rescate la existencia de muchos caracoles terrestres, un fragmento de Cardium sp. y la taba de un gran herbívoro.
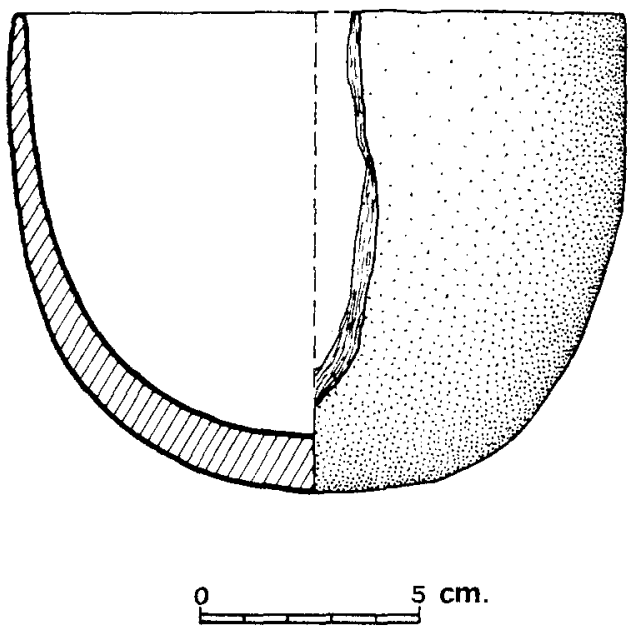

a
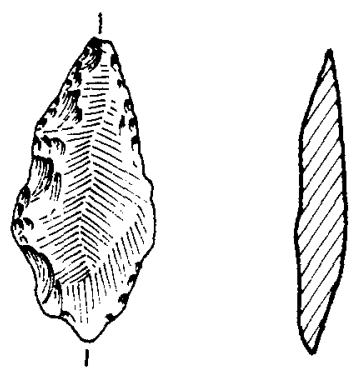

b
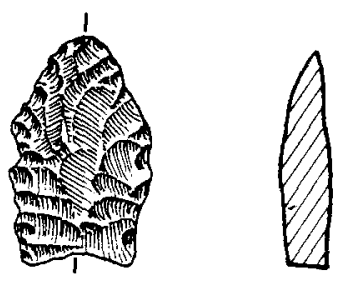

o $3 \mathrm{~cm}$.

1. Casa Paus (Novelda) 
Llama poderosamente la atención el lugar elegido como asentamiento, en una suave elevación, sin defensas naturales ni aparentemente artificiales. Esto, junto con algunos materiales, como pueden ser las puntas de flecha y las numerosas láminas de sílex, nos indujeron en un principio a considerar Casa Paus como un yacimiento eneolítico.

Sin embargo, las viviendas cuadrangulares, la cerámica pulimentada, el fragmento carenado y los dientes de hoz son elementos que apuntan más hacia la Plena Edad del Bronce. Mientras que el brazalete de arquero y el resto de las cerámicas pueden aparecer en uno u otro horizonte, si bien suelen indicar cierto primitivismo cuando el hallazgo se hace en contextos del Bronce.

Por todo ello, pensamos que Casa Paus o El Trial es un poblado, no de altura, del tránsito del Eneolítico al Bronce Pleno, como puede ocurrir con la última fase de la Ereta del Pedregal, en Navarrés (Valencia). Sin embargo, en este caso la pobreza de materiales no permite apuntar las precisiones a que ha podido llegarse en La Ereta del Pedregal. Y, entre las cosas que pudieran echarse en falta, está la cerámica campaniforme, como elemento significativo en relación con la datación que proponemos. Pero, independientemente de que algún día pudiera aparecer, no creemos que en el País Valenciano deba tomarse como norma inalterable la presencia de campaniforme en los momentos finales del Eneolítico de todos y cada uno de los yacimientos.

\section{CASA ROMA}

Recibe este nombre un pequeño cabezo situado al borde del Vinalopó, próximo a la Casa Romá, de la que recibe el nombre, en el término municipal de Novelda (Alicante). Coordenadas geográficas: $38^{\circ} 24^{\prime} 58^{\prime}$ ' lat. N. y $0^{\circ} 47^{\prime} 45^{\prime \prime}$ long. W. del meridiano de Greenwich.

Fue prospectado por el Grupo de Rescate 688 en 1975 o 1976 y por nosotros en 1977, habiendo sido publicada una breve nota (GRUPO DE RESCATE 688: p. 61).

Sus laderas son abruptas, impracticables por algunos sectores. El propio río con sus avenidas contribuye a ello, ya que ha socavado las vertientes W. y S. De esta manera, su perímetro ha ido reduciéndose, a lo que han colaborado las lluvias, las cuales han arrastrado fácilmente los materiales blandos que componen el cabezo.

Situado en el punto de confluencia del río Vinalopó con el Barranco de Salinetas, pudo observarse que en el mes de junio ambos llevaban agua.

En superficie no quedan restos de muros. Tan sólo algunos fragmentos de cerámica, trozos atípicos de sílex y fragmentos de Cardiun sp. Además, la Colección Rescate del Colegio Padre Dehón de Novelda guarda dos molinos naviformes. En marzo de 1979 V. Gómez García recogió algunos trozos más de cerámica y de sílex. (Información de don Vicente Gómez).

La mayoría de los materiales pertenecen a la Plena Edad del Bronce, aunque su escasez no permite mayor concretización. No obstante, hallamos un fragmento muy erosionado de un pequeño plato cilindrico, seguramente romano. Este hecho no es extraño si tenemos en cuenta que por el río circulaba una calzada romana y frente a Casa Romá - en El Sambo- existe restos de un establecimiento de aquella época. 


\section{CASTILLO DE LUNA O DE LA MOLA}

El Castillo de Luna se levanta sobre un cerro escarpado, el cual constituye la estribación oriental del Cerro de la Mola, en el término municipal de Novelda (Alicante). Coordenadas geográficas: $38^{\circ} 24^{\prime} 28^{\prime \prime}$ lat. N. y $0^{\circ} 46^{\prime} 56^{\prime}$ ' long. W. del meridiano de Greenwich.

Este cerro posee unas excelentes condiciones estratégicas, ya que su acceso está impedido en gran parte por escarpes y pendientes empinadas. Desde su cima se domina el cauce del río Vinalopó y su valle medio. En la cima existen las ruinas de un castillo medieval, el cual posee un recinto amurallado con torreones y dos torres centrales construidas en diferentes momentos, una de ellas Monumento Nacional. Las murallas, de tapial, fueron construidas en época mulsumana sobre las ruinas de otras romanas, o íbero-romanas.

Hallazgos de estos períodos se han venido realizando en la cima y laderas con ocasión de labores agrícolas o trabajos de otro tipo. Sin embargo, algunos vestigios demuestran que antes que los íberos y romanos hubo un asentamiento de la Edad del Bronce, totalmente arrasado por las ocupaciones posteriores y por el santuario de Sta. María Magdalena que allí se construyó.

Las laderas ofrecen gran cantidad de cerámica, la mayoría de época medieval. Sin embargo, es posible encontrar algunos objetos de la Edad del Bronce, como algunos trozos de sílex y fragmentos de cerámica. La colección de M. Romero Iñesta guarda dos fragmentos de cerámica a mano; varios dientes de hoz y lascas de sílex; un pequeño molino naviforme y parte de otro mayor; y una mano de mortero cónica en granito verde.

\section{LA ESPARRAGUERA}

La Esparraguera es un pequeño cabezo situado al Sur del Cerro de la Mola y a $600 \mathrm{~m}$. del Vinalopó, en el término municipal de Novelda (Alicante). Coordenadas geográficas: $38^{\circ} 23^{\prime} 34$ lat. N. y $0^{\circ} 47^{\prime} 53^{\prime}$ ' long. W. del meridiano de Greenwich.

Sus laderas oriental y occidental son de muy difícil acceso por la presencia de masas rocosas, mientras que las vertientes Norte y Sur son muy pendientes. Su cima rocosa se levanta a unos $336 \mathrm{~m}$. s.n.m. y el poblado estaría situado en los rellanos bajo ella, desde donde se domina todo el valle.

Actualmente está impedido su acceso por unas alambradas que han dispuesto sus propietarios, que han sembrado pinos y lo han convertido en coto de caracoles. Gracias a ello no ha sido arrasado por los clandestinos. V. Gómez García ha prospectado el cerro en varias ocasiones y de él se dio una breve noticia en 1978 (GRUPO DE RESCATE 688: 1978, p. 62).

La Colección Rescate del Colegio Padre Dehón citado, guarda los siguientes materiales de La Esparraguera:

Parte superior de una vasija troncocónica invertida con una línea de carena muy alta, la pasta es regular, la superficie de color rojizo y muy espatulada (40 $\mathrm{cm}$. diám. máx.) (fig. 2, a). Fragmentos del cuello de una vasija, hiperbólico pasta cuidada, color marrón claro y bien espatulada (fig. 2, c). Varios fragmentos de cuencos de boca bastante abierta y un borde exvasado, de pasta cuidada, 


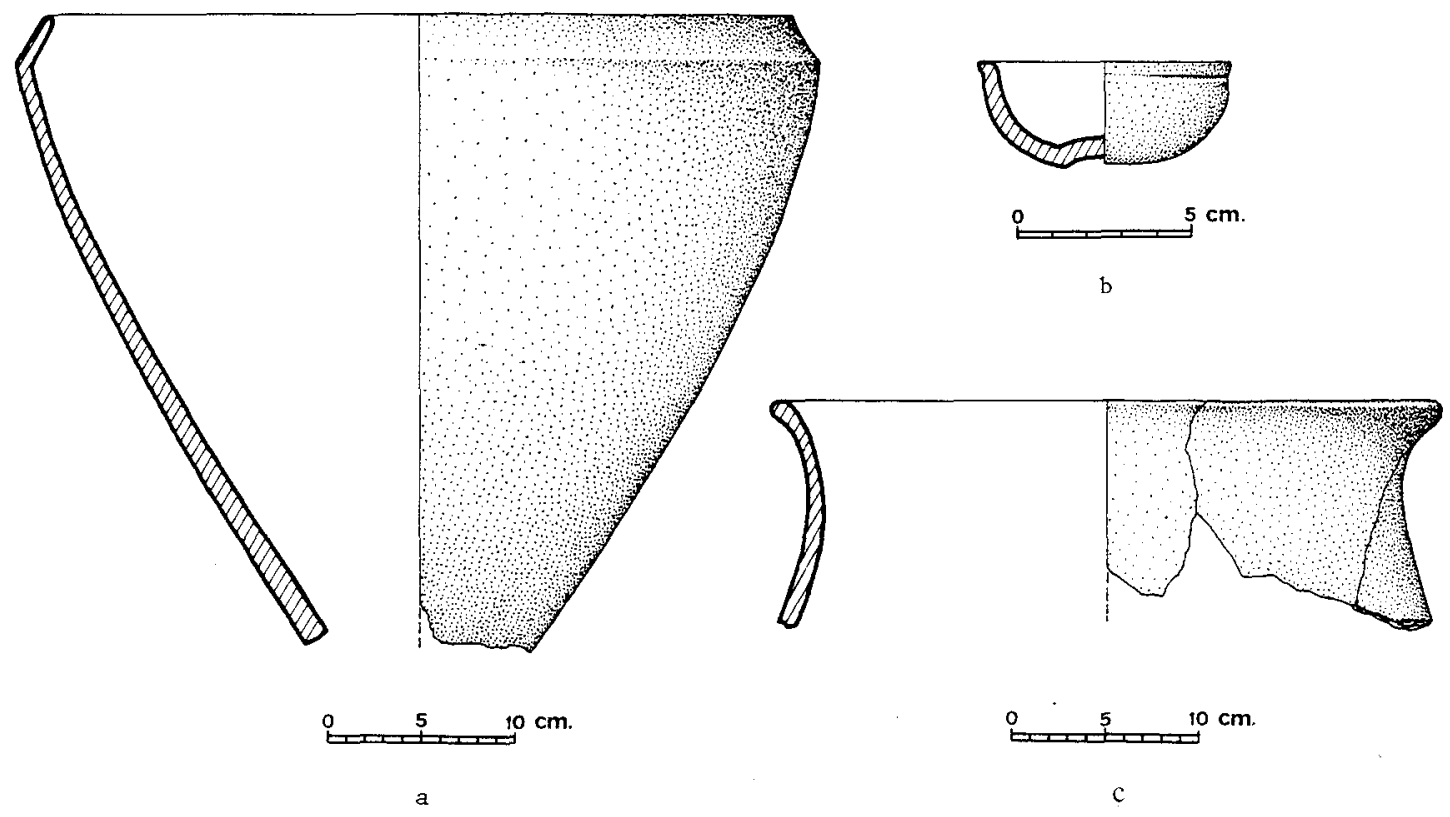

2. La Esparraguera (Novelda)

superficies pulimentadas (a veces muy bruñidas) y color negruzco. Otros fragmentos similares. Un pequeño cuenco semiesférico con ónfalo, pasta cuidada, color grisáceo y alisado (7,3 $\times 2,8 \mathrm{cms}$.) (fig. 2 , b).

Una azuela de piedra verde oscura con bisel en el extremo distal y en talón. Fragmento de canto rodado de granito gris con señales de uso como percutor. Un molino naviforme.

V. Gómez García nos mencionó, además, la presencia de pectúnculos (Glycimeris s.p.) perforados y objetos de sílex.

Su inclusión en la Edad del Bronce está clara, pero el vaso cónico y el cuenco con ónfalo implican una cronología tardía y no son corrientes en el Bronce Valenciano.

\section{LA LLOMA REDONA}

\section{Situación}

La Lloma Redona o Reona está situada en el término municipal de Monforte del Cid (Alicante), en las estribaciones meridionales de la Sierra del Cid, al Es- 
te de la Serreta o Serreta Llarga. Coordenadas geográficas: $38^{\circ} 24^{\prime} 39^{\prime \prime}$ lat. N. y $0^{\circ} 42^{\prime} 36^{\prime}$ ' long. 'W.

Tiene forma aproximadamente cónica, aunque alargada de WSW. a WNE., y una altitud de 371 m. s.n.m. La vertiente septentrional termina en unos escarpes que coronan la cima. Por el contrario estos escarpes no existen en la vertiente meridional, donde la pendiente es más suave.

\section{Historia de la investigación}

Nosotros la habíamos visitado hace años, ante la noticia de que en sus laderas había «cosas de moros», pero sin resultado positivo, al ignorar que el yacimiento se encontraba justamente en la cima y no en las laderas. En 1976 el Grupo de Rescate 689 prospectó la loma, descubriendo en la parte alta los restos de un poblado fortificado muy cubierto por el espartal. Este descubrimiento se intentó mantener fuera del conocimiento de los aficionados de Novelda, dado que aparentemente el yacimiento estaba intacto. Sin embargo, cuando en 1977 volvimos a visitarlo en compañía del profesor jefe del citado Grupo, V. Gómez García, el poblado ya estaba parcialmente revuelto, afectando las remociones al sector en que el relleno arqueológico era más potente. Posteriormente se supo que algún antiguo miembro del citado Grupo y diversos coleccionistas de Novelda habían sido los autores.

En 1978 se dio a conocer en breve nota (GRUPO DE RESCATE 688: 1978, p. 63).

\section{El poblado y sus estructuras constructivas}

El poblado ocupa la parte de la cumbre que mira hacia el Sur, protegida su espalda por el escarpe mencionado. Las restantes vertientes (WSW., SSE. y ENE.) son de más fácil acceso, aunque poseen una considerable pendiente. Por allí se dispuso una muralla en forma de arco, de la cual se conserva aún gran parte.

Para la construcción de dicha muralla se allanó artificialmente el terreno, mediante un escalón de piedras y tierra. Sobre él se levantó la construcción defensiva a base de piedras de mediano tamaño en seco que forman un aparejo irregular. Es imposible seguir en la actualidad toda su longitud, pues las remociones y el tiempo la han deteriorado en varios puntos. Tampoco es posible saber a simple vista su grosor, ya que su cara interna está colmatada por los sedimentos. La altura conservada actualmente llega en algunos puntos a $1 \mathrm{~m}$.

Antes de su destrucción parcial, afloraba en superficie en el interior del recinto una alineación de piedras en forma circular, quizás un fondo de cabaña. Posteriormente pudimos observar que las remociones habían puesto al descubierto la planta de una vivienda de tendencia trapezoidal muy afectada por las excavaciones clandestinas. Allí el relleno alcanzaba aparentemente 0'60 m., aunque en la mayor parte de la zona removida la potencia oscilaba entre $0,10 \mathrm{~m}$. y $0,50 \mathrm{~m}$. Bajo un estrato de tierra vegetal aparecía otro de tierra grisácea con alto contenido de cenizas mezcladas con trozos de cerámica, carbones y pellas de 
arcilla mezclada con ceniza que conservaban las improntas de cañas, pequeñas ramas y hojarasca.

Otros restos de muros afloran en distintos puntos del poblado, si bien es imposible sin una excavación determinar la forma y dimensiones de las construcciones.

\section{Sepulturas}

Hemos recogido la información oral de un agricultor de la zona, el cual tenía vagas noticias del descubrimiento de unos enterramientos en la Lloma Redona $o^{-}$en los alrededores. Sin embargo, esta comunicación es tan imprecisa que objetivamente no podemos extraer de ella ninguna conclusión válida.

\section{Materiales muebles}

Por la cima y laderas abundan los fragmentos de cerámica de diversos tipos, desde la tosca y de paredes gruesas, hasta los trozos de pequeños cuencos de paredes estrechas, pasta cuidada y superficie bruñida. También algunos dientes de hoz.

La Colección Rescate de Colegio Padre Dehón, de Novelda, posee de este poblado un cuenco semielipsoide asimétrico, con dos mamelones colocados asimétricamente cerca del borde, pasta poco cuidada, superficie negruzca con tosco espatulado ( $22 \mathrm{cms}$. diám. máx. y $18 \mathrm{cms}$. alt.) (fig. 4, c). Otros fragmentos de cerámica similar. Tres dientes de hoz en sílex melado; cuatro lascas atípicas.

La colección M. Romero Iñesta cuenta con un cuenco semiesférico de pasta cuidada, superficie gris oscura y pulimentada $(13,2 \mathrm{cms}$. diám. y $6,6 \mathrm{cms}$. alt.) (fig. $3, \mathrm{c}$ ). Pequeño vaso de tendencia esférica con borde recto, pasta poco cuidada, color beige al gris oscuro, espatulada $(9 \mathrm{cms}$. diám. máx. y $7,5 \mathrm{cms}$. alt.) (fig. 3, b). Vaso de tendencia esférica con borde marcadamente exvasado y tres mamelones cerca del borde, pasta regular, color marrón rojizo al gris e intenso espatulado $(24,8 \mathrm{cms}$. diám. máx. y $17,4 \mathrm{cms}$. alt.) (fig. 4, a). Vaso de tendencia esférica con borde exvasado y cuatro mamelones cerca del borde, pasta regular, superficie marrón oscura y espatulada $(23,2 \mathrm{cms}$. diám. máx. y $20 \mathrm{cms}$. alt.) (fig. 4 , b). Vasija ovoide con cuello muy exvasado y dos asas de lengüeta perforadas en los hombros, pasta cuidada, superficie beige oscura y alisada (fig. 3, a). Un fragmento de cerámica rojiza con un asa de lengüeta horizontal perforada. Otro fragmento negruzco con una serie de mamelones en hilera desde el borde hacia abajo. Tres pesas de telar, una cilíndrica con dos agujeros juntos; otra piriforme con un agujero; la tercera elipsoidal con cuatro agujeros.

La industria lítica en esta colección está representada por un hacha pulimentada; cuatro lascas de sílex marrón sin retoques; otra retocada; nueve dientes de hoz en sílex blanco y gris.

Hay cinco conchas de pectúnculo (Glycerimis sp.) con el natis perforado. 

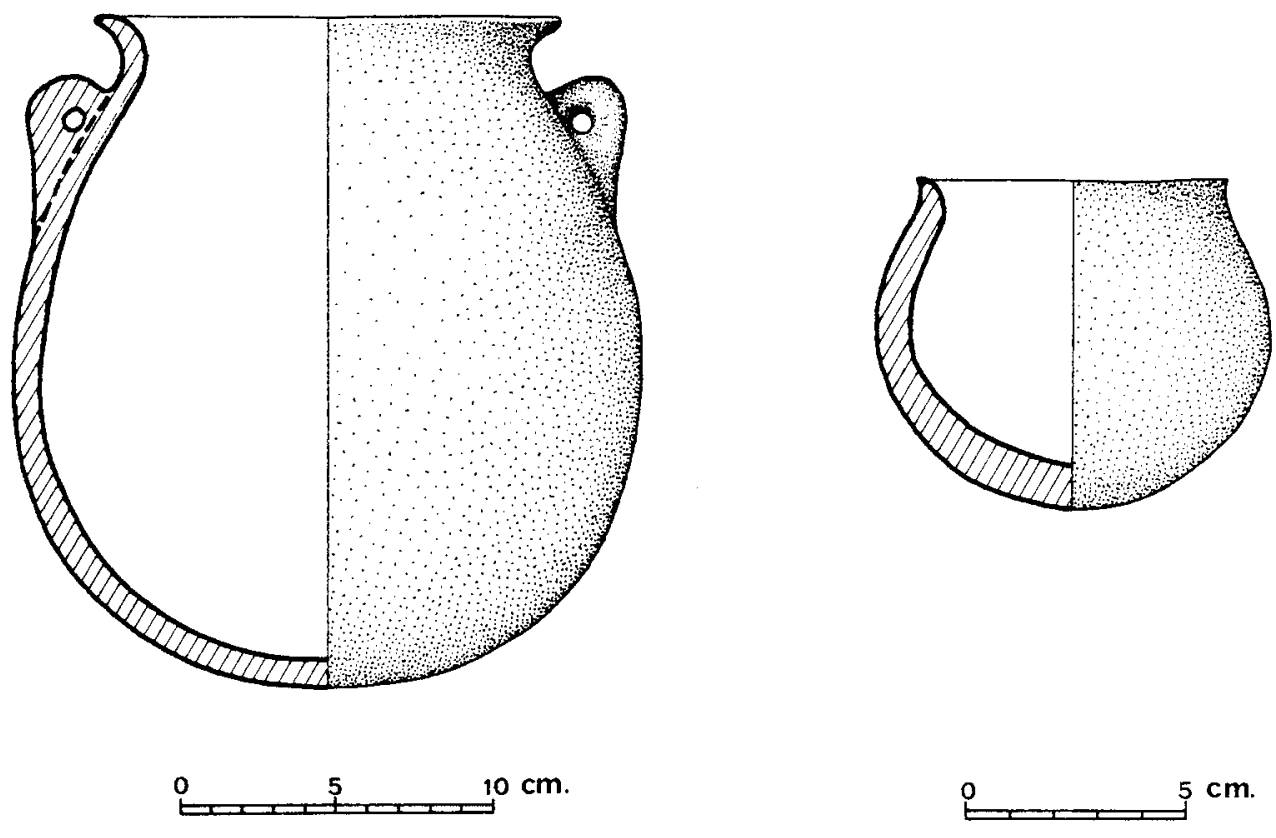

a

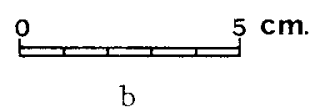

b
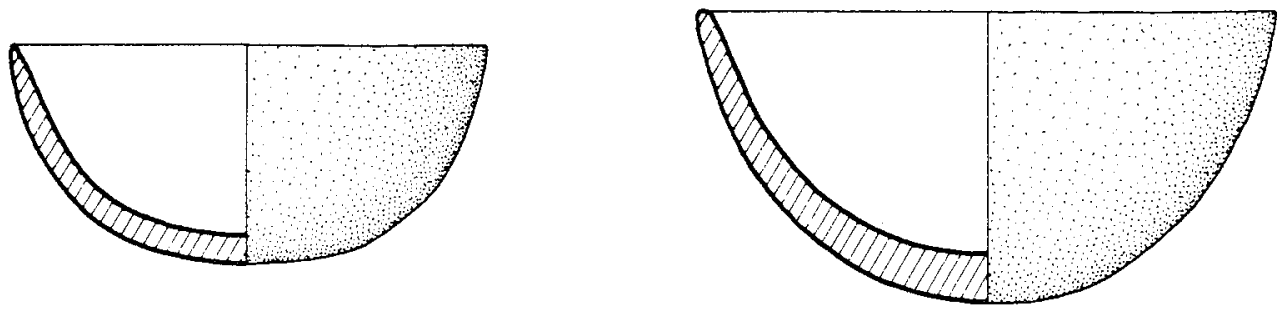

c $5 \mathrm{~cm}$.

$d$

3. La Lloma Redona (Monforte del Cid)
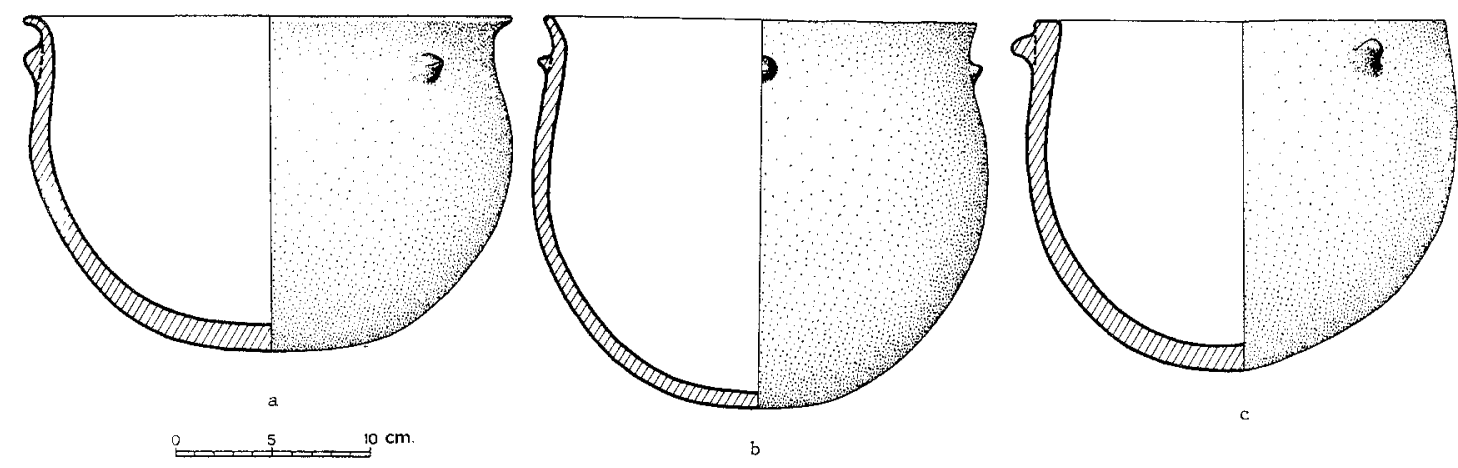

4. La Lloma Redona (Monforte del Cid) 


\section{EL MONTAGUT}

El Montagut es un elevado cerro de laderas muy pendientes y cumbre puntiaguda (de ahí su nombre), que alcanza $560 \mathrm{~m}$. s.n.m. Su mole destaca en el Valle Medio del Vinalopó, dominándose desde su cima un panorama muy extenso. Está situado a $2.700 \mathrm{mts}$. al Norte de Novelda (Alicante) y a $1.800 \mathrm{mts}$. del cauce del río. Coordenadas geográficas: $38^{\circ} 25^{\prime} 14^{\prime \prime}$ lat. N. y $0^{\circ} 45^{\prime} 56^{\prime \prime} \log$. W. del meridiano de Greenwich.

Fue prospectado por el Grupo Rescate n. ${ }^{\circ} 698$ del Colegio Padre Dehón, que lo visitó en varias ocasiones. También algún aficionado local llevó a cabo varias rebuscas. En 1978 se publicó una breve reseña (GRUPO DE RESCATE 688: 1978, pp. 62-63).

En dos puntos bajo la cima existen vestigios de asentamientos al aire libre. El primero, al cual corresponden las coordenadas geográficas que hemos dado, está situado en la parte Norte, al abrigo de un grupo de rocas. Allí se observan algunas piedras puestas intencionalmente, aunque la frondosa vegetación a que ha dado lugar el relleno del habitat, impide en cierta manera identificar la forma de la o las viviendas. En la cara S-SE, en un rellano de la roca existe relleno arqueológico de tierras cenicientas aunque sin restos de muros. En ambos sitios existen materiales arqueológicos.

Además, han sido descubiertas dos cuevas. La primera (Cueva del Montagut-I), hallada hace años en la cara Sur, bajo la cima, presentaba en su interior y por la ladera inmediata restos arqueológicos y antropológicos que inducen a considerarla un posible lugar de enterramiento. De la segunda (Cueva del Montagut-II) hallada en 1976 ó 1977, no conocemos con exactitud su ubicación y sus vestigios son propios de un lugar de habitación.

En la parte del poblado situado en el S-SE. el Grupo de Rescate n. 689 recogió un fragmento de cerámica incisa y otros trozos de cerámica; un molino naviforme y trozos de otros; dientes de hoz y otros útiles de sílex. Materiales que no hemos podido estudiar por no encontrarse actualmente en la Colección Rescate $y$ de ellos sólo tenemos la información de V. Gómez García (V. GOMEZ GARCIA: 1976, p. 10).

En la cueva I se recogió cerámica; varios molinos y fragmentos de otros; piezas móviles de molino; una afiladera; varios sílex; dos costillas y un fémur humano. De ello, sólo pudimos estudiar una sierra doble, en lámina de sílex melado de sección trapezoidal; un diente de hoz en sílex marrón, y un fragmento de una gran vasija de borde exvasado, con dos o más mamelones cercanos al borde, pasta regular, superficie beige - marrón- gris y con pulimento imperfecto.

De la cueva II hay en la Colección Rescate una vasija de tendencia esférica a lenticular, con fondo plano y dos mamelones aplanados, prácticamente asas de lengüeta, junto al borde; pasta grosera, superficie marrón grisácea y espatulada (18,9 cms. diám. máx. y $14 \mathrm{cms}$. alt.) (fig. 5, b). Dos bordes exvasados de vasijas medianas de pasta grosera y color negruzco.

La colección de M. Romero Iñesta guarda una serie de materiales que proceden en conjunto de las cuevas y establecimientos al aire libre, sin que podamos diferenciar unos de otros por no existir constancia: un cuenco de fondo paraboloide y paredes ligeramente entrantes, pasta poco cuidada, superficie irregular 
de color gris oscuro y marrón grisáceo $(12,4 \mathrm{cms}$. diám. máx. y 7,5 cms. alt .) (fig. 5, a); cuatro fragmentos de cerámica con mamelones, pasta poco cuidada, superficie color negruzco en tres y rojizo en uno, uno está pulimentado. La industria lítica está representada por un molino naviforme de caliza; una pieza móvil de molino en caliza y de forma discoidal; una especie de percutor esferoide de granito; de sílex gris hay dos dientes de hoz; en sílex blanco, melado, negro y melado oscuro cinco lascas sin retoques; una lámina de sílex blanco con retoques de uso. Además, una concha de Glycimeris sp. perforada y nueve caracoles terrestres (Iberus alonensis) con agujero.

El Montagut es un asentamiento de la Edad del Bronce, aunque la pobreza de sus materiales es notable y parece existir una fuerte tradición eneolítica.
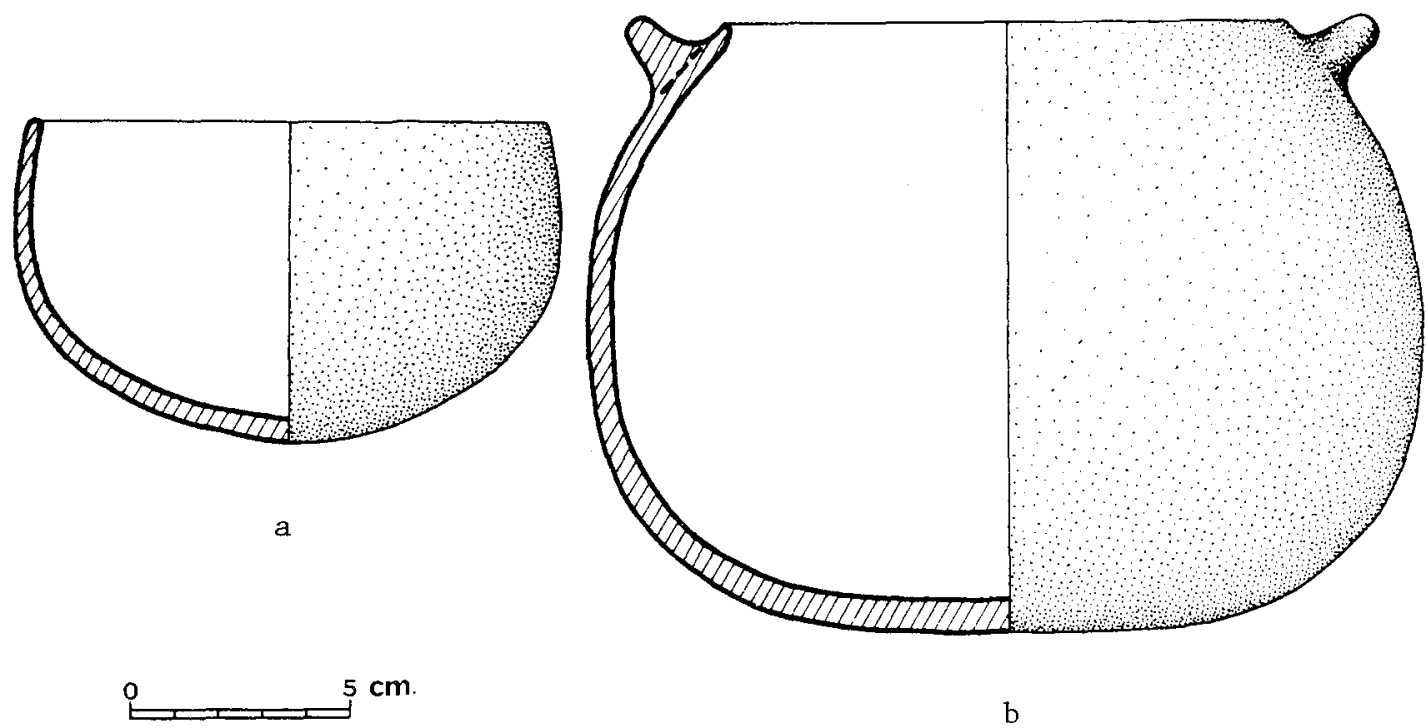

$\mathrm{b}$

\section{El Montagut (Novelda)}

\section{EL MURON}

\section{Situación}

El Murón es un cerro aislado, situado en las estribaciones septentrionales de la sierra de la Horna, en el término municipal de Aspe (Alicante). Coordenadas geográficas: $38^{\circ} 21^{\prime} 02^{\prime}$ ' lat. N. y $0^{\circ} 48^{\prime} 30^{\prime \prime}$ long. W. del meridiano de Greenwich.

El tercio superior del cerro está separado del resto por un escape que lo rodea por todos lados, excepto por la vertiente Norte y un estrecho acceso en el SE. Se sitúa así en un punto sumamente estratégico, desde el que se domina per- 
fectamente el Valle Medio del Vinalopó y el paso natural que pone en comunicación el Valle Bajo del Vinalopó - la vega ilicitana - con el Valle Medio.

Su silueta destaca desde lejos por la gran mancha blanca que constituye una cantera abierta en la ladera oriental, y que en la actualidad está abandonada. En la zona también se le conoce por otros nombres, además del que nosotros utilizamos por el ser más extendido. Así es posible oírlo llamar «La Horna», «La Forna» o «El Murón de la Horna», y por alguna de estas denominaciones ha sido dado a conocer en breves notas (D. JIMENEZ DE CISNEROS: 1925, p. 71. GRUPO DE RESCATE 688: 1978, p. 64).

\section{Historia de la investigación}

El Murón ha venido siendo objeto de rebuscas de aficionados desde hace muchos años. Al menos, en todo lo que va del siglo. En los primeros años de 1900 prospectó el yacimiento D. Jiménez de Cisneros (1925). Posteriormente - hacia 1930- se efectuaron excavaciones, según tradición oral, de las cuales existen vestigios de la plataforma superior. En 1975 y en fechas posteriores fue prospectado por el Grupo de Rescate 688 del Colegio Padre Dehón, de Novelda, habiendo publicado una nota en 1978 (GRUPO DE RESCATE 688: 1978, p. 64). Nosotros lo visitamos en 1977 y 1978, la primera vez acompañados por V. Gómez García, profesor-jefe del citado Grupo. Entre una y otra visita, la acción destructiva de los clandestinos había aumentado sensiblemente.

En septiembre de 1980 se llevó a cabo la primera campaña de excavaciones científicamente planteada, dirigida por M. S. Hernández Pérez. En ese momento, parte de las estructuras observadas por nosotros dos años antes habían sido destruidas.

Tras el levantamiento topográfico de la zona a excavar, se realizaron trabajos en dos cortes (A-3 y B-5) y en una covacha sepulcral de la ladera noroccidental.

En el verano de 1981 se realizó la segunda campaña de excavaciones, ampliando la zona de trabajo a tres nuevos cortes (M. S. HERNANDEZ PEREZ: 1980, pp. 2-4. Agradecemos a su excavador el habernos facilitado copia del Informe preliminar de la campaña de 1980).

\section{El poblado y sus estructuras constructivas}

El poblado debió extenderse por la cima y laderas del cerro, adquiriendo un notable desarrollo, a juzgar por los restos que han quedado tras la acción de los furtivos.

Sobre el escarpe citado se extiende una plataforma a la que ya hemos hecho alusión. Esta se encuentra defendida mediante un recinto amurallado, actualmente muy arrasado. En la cara Norte, donde el escarpe se interrumpe, no existiendo accidentes naturales que defiendan el acceso se reforzó el recinto fortificado mediante dos bastiones aparentemente semicirculares separados por una roca y que conjuntamente abarcan un espacio frontal de unos $14 \mathrm{mts}$. En 1977 alcanzaban una altura de 1,60 mts., estando hoy en día algo más afectadas. En 1980 se planteó un corte (corte B-5) que afectaba a uno de los bastiones, com- 
probándose que el paramento se componía de piedras de tamaño regular sin labrar ni argamasa. Tan sólo en la parte inferior aparecen unidas las piedras de las hiladas exteriores mediante barro, el cual, cuando la base del muro se apoya en la roca, forma una capa que evita posibles desplazamientos. También se observó, al dejar al descubierto el muro, que éste hacía una inflexión. Esto reveló que el bastión, aparentemente semicircular, tiene posiblemente una planta poligonal, lo cual deberá ser comprobado convenientemente en las próximas campañas.

La muralla parece que debió rodear la plataforma, pues había restos suyos, aunque muy mal conservados. No así en el sector SE., donde existe un paso natural a través del escarpe. Allí es posible que en su momento también existiera, pero las rebuscas han impedido que se conserve el aspecto original de este punto de acceso.

A espaldas de la plataforma se levanta un macizo de rocas que constituye la cima del cerro y defiende al poblado por su parte meridional.

En el interior de este recinto existieron viviendas, de las que en nuestras prospecciones solamente pudimos identificar un muro. Pero no cabe duda de que las viviendas llegaron a extenderse mucho extramuros, sobre todo por la ladera nororiental y también, aunque en menor proporción, por la ladera septentrional y al pie del citado acceso SE. Los restos de viviendas muy destruidas son abundantes en la ladera NE. El relleno arqueológico parece haber sido considerable en algunos puntos, a la vista de los profundos hoyos de excavadores furtivos.

Allí abundan grandes trozos de mortero de arcilla grisácea, con alto contenido de cenizas y partículas vegetales, las cuales presentan improntas vegetales en una de sus caras. Estas improntas son algunas veces de esparto y es muy probable que su abundancia indique que muchas veces las paredes de las viviendas estuvieron en gran parte formadas a base de este material, si bien parece seguro que existió por lo menos un zócalo o murete de piedras, a juzgar por las muchas que existen por la ladera y los restos de algunos de ellos.

Las excavaciones de M. S. Hernández afectaron a dos viviendas, una situada en la plataforma superior y otra en la ladera NE. La primera se incluye, en parte, en el corte A-3, el cual ofreció dos niveles separados por un derrumbe de piedras de diverso tamaño procedente de los muros y pellas de barro con improntas vegetales que formarían parte de la techumbre. El nivel I ofreció escaso material arqueológico. El nivel II presentó dos muros unidos en ángulo de $90^{\circ}$, pertenecientes a una misma vivienda y de los cuales sólo se conservaban una o dos hiladas de piedras en seco. El pavimento de la vivienda estaba formado por una capa de barro y cenizas, en el que se encontró encajonada una muela durmiente de molino naviforme. En la parte exterior de la vivienda existía otro muro que se asoció al relleno sobre el que estaba levantada la citada vivienda, por lo que se consideró la existencia de una superposición.

La segunda vivienda se encontraba muy afectada por las rebuscas de aficionados. Estaba adosada a unos afloramientos rocosos y su planta era rectangular (M. S. HERNANDEZ PEREZ: 1980, p. 3). 


\section{Sepulturas}

Las laderas de El Murón presentan numerosas grietas y covachas, sobre todo por la parte noroccidental. A fin de comprobar la validez de la opinión manifestada por M. Tarradell (M. TARRADELL MATEU: 1963, p. 67) sobre que el sistema de inhumar los cadáveres en el Bronce Valenciano fue en covachas situadas cerca del poblado, M. S. Hernández Pérez excavó una de aquéllas.

En este caso se trata de una estrecha grieta con una anchura máxima de 0,44 $\mathrm{m}$. En la superficie había maleza y piedras sueltas, así como dos fragmentos amorfos de cerámica. Bajo una capa de tierra estéril de $0,29 \mathrm{~m}$., se halló una cista de $0,40 \times 0,29 \mathrm{~m}$. y $0,34 \mathrm{~m}$. de alto, que aprovechaba las paredes de la grieta. En su interior se hallaron restos humanos muy fragmentados pertenecientes, al menos, a tres individuos infantiles (M. S. HERNANDEZ PEREZ: 1980: pp. 4-5).

\section{Materiales muebles}

La colección de M. Romero incluye: Una vasija de tendencia paraboloide de fondo plano, borde ligeramente exvasado y decorada con siete pares de grandes mamelones puntiagudos, pasta cuidada, superficie marrón rojiza oscurecida por zonas, y bien espatulada y alisada $(42 \mathrm{cms}$. diám. y $28 \mathrm{cms}$. alt.) (fig. 6, b y lám. II, c). Gran vasija ovoide, pasta cuidada, color marrón oscuro-negruzco y ligero bruñido ( $40 \mathrm{cms}$. diám. máx. y $43 \mathrm{cms}$. alt.) (fig. 6, a). Vasija de fondo paraboloide y paredes hiperboloides, pasta regular, superficie gris negruzca y espatulada $(27,2 \mathrm{cms}$. diám. máx. y $33,1 \mathrm{cms}$. alt.) (fig. 8, a). Estas tres vasijas

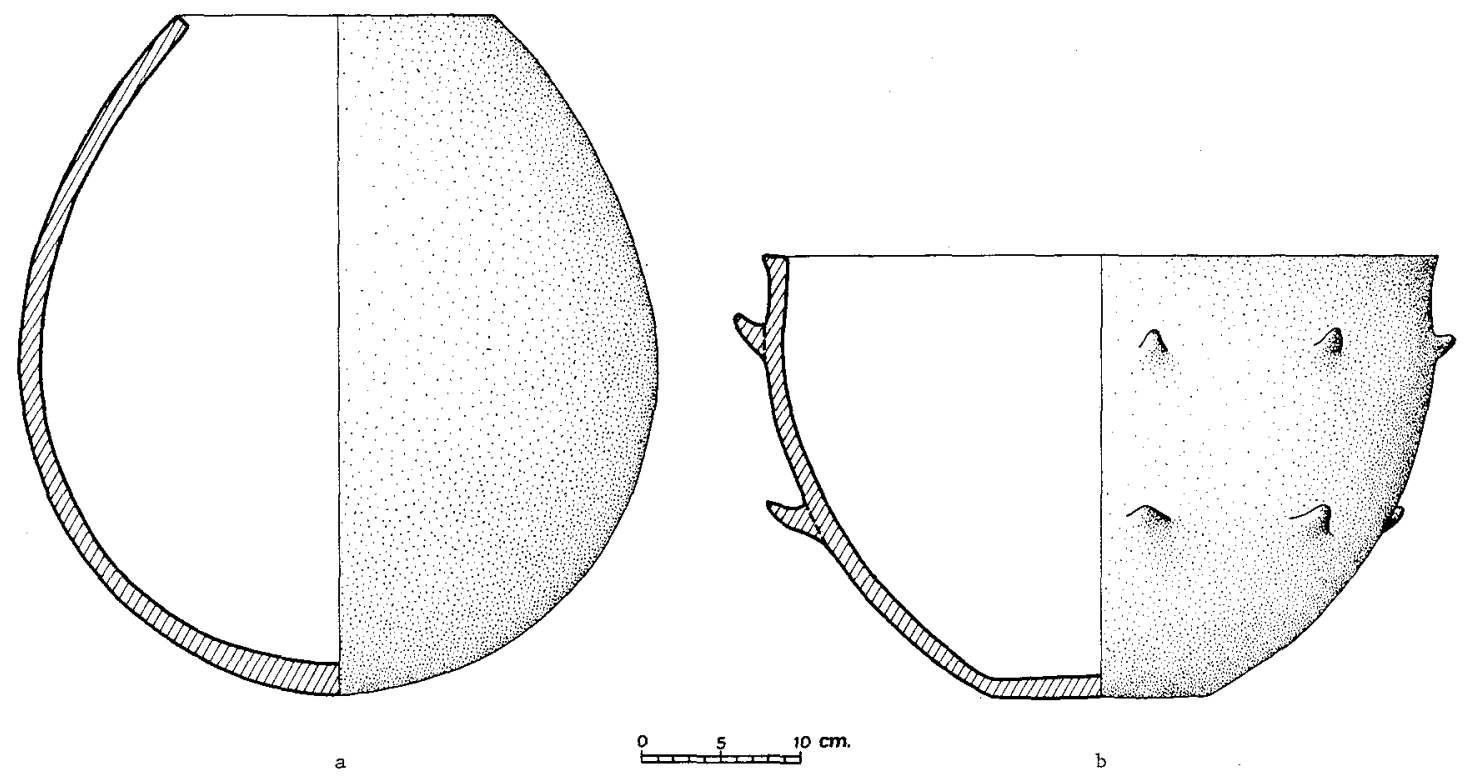

6. El Murón (Aspe) 
aparecieron juntas. Cuenco de fondo plano y paredes casi rectas, pasta cuidada, superficie erosionada, aunque probablemente estaba pulimentada $(24 \mathrm{cms}$. diám. y $9 \mathrm{cms}$. alt.) (fig. 8, b). Cuenco similar, color beige claro y superficie pulimentada (24,8 cms. diám. 10,6 cms. alt.) (fig. 8 , c). Vaso semielipsoide, de pasta cuidada, superficie beige con manchas negruzcas y pulimentada $(23,9 \mathrm{cms}$. diám., 15,6 cms. alt.) (fig. 7, d). Pequeño vaso elipsoide con borde envasado, pasta poco cuidada, color gris-marrón grisáceo y espatulada $(8,2 \mathrm{cms}$. diám. máx., y $8 \mathrm{cms}$. alt.) (fig. 7, b). Vaso de forma similar, pero con pequeño fondo
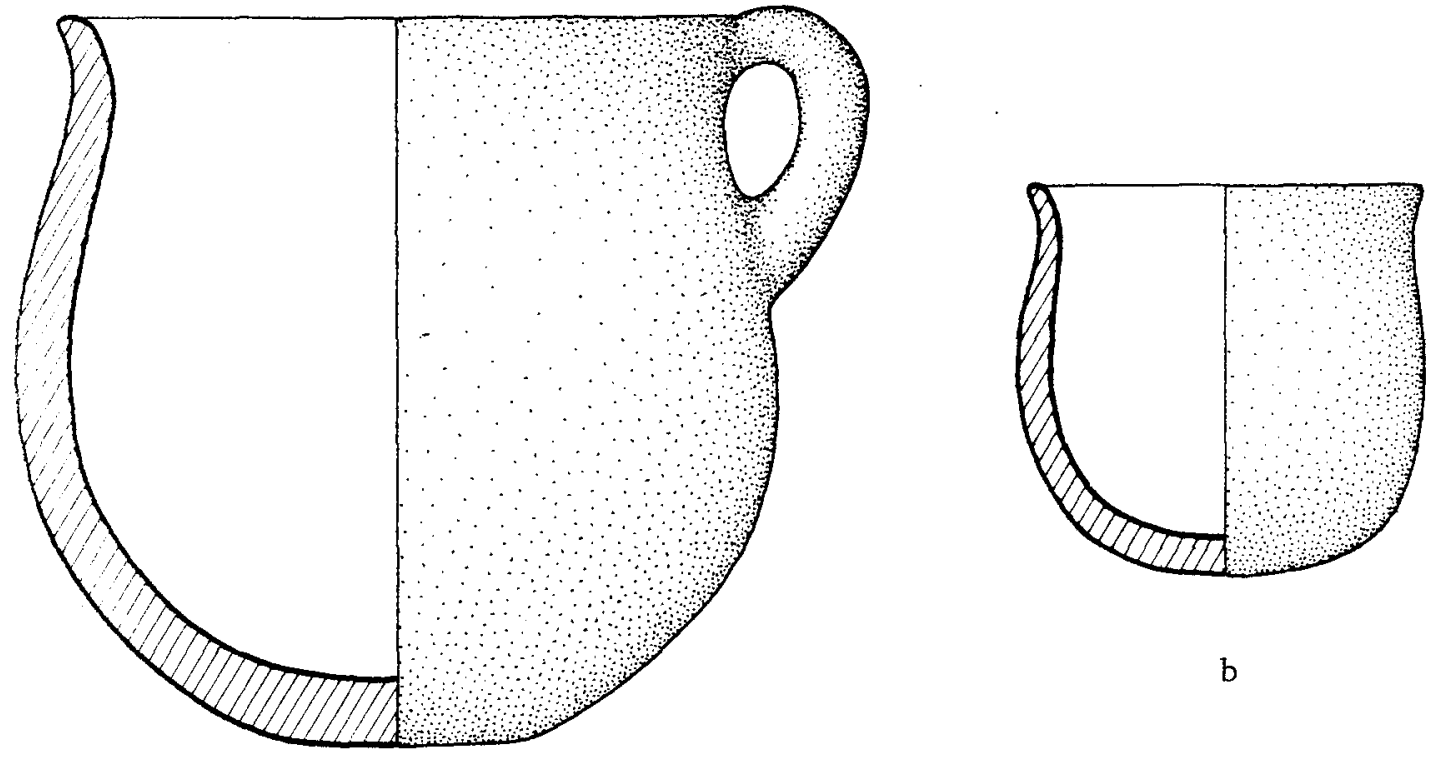

a
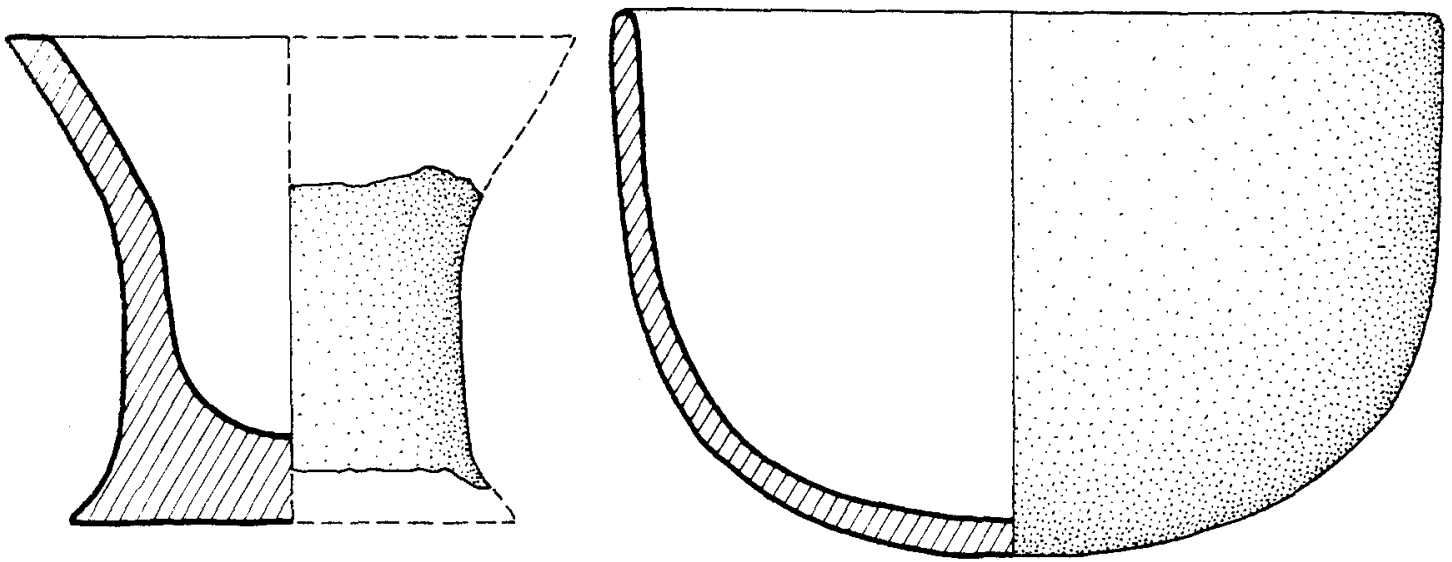

c

d

$5 \mathrm{~cm}$.

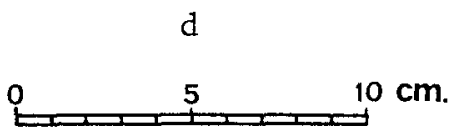

7. El Murón (Aspe) 
plano y un asa de cinta que rebasa el borde, pasta regular, color beige amarillento y alisada $(15,5 \mathrm{cms}$. diám. máx. y $15 \mathrm{cms}$. alt.) (fig. 7, a). Vaso bitroncocónico en forma de copa con ancho pie, pasta cuidada, superficie negruzca y bruñida (11,6 cms. diám. máx. $10 \mathrm{cms}$. alt .) (fig. 7, c., en blanco la parte restaurada). Dos pesas de telar cilíndricas con un orificio central. Tres fragmentos de bordes de vasijas, uno de ellos con una prolongación del borde bajo ésta.
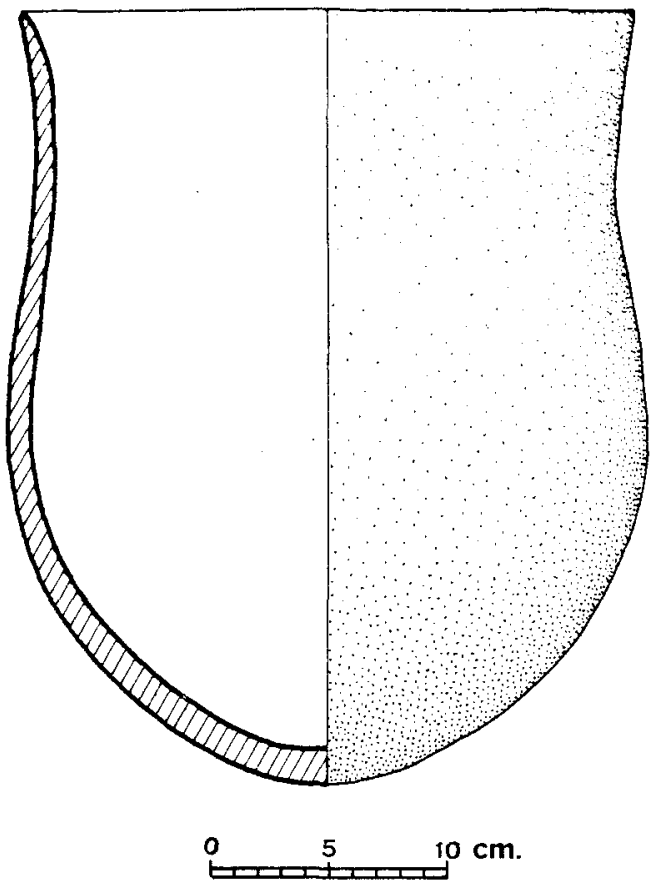

a
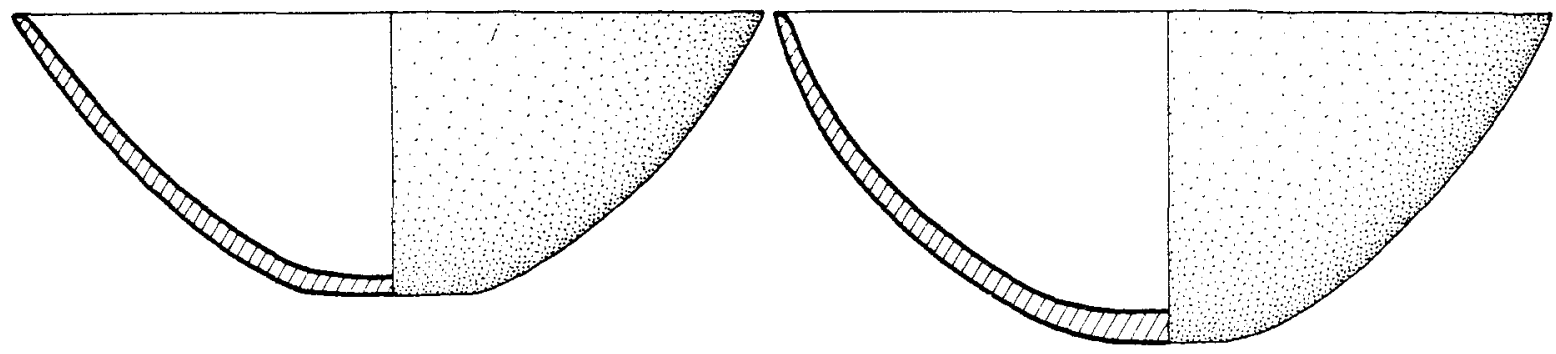

b

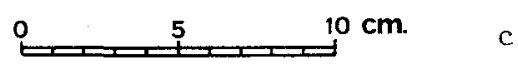


La industria lítica está formada por: un molino naviforme de caliza; otro gran molino naviforme de caliza con un hoyo o mortero central de $15 \mathrm{cms}$. de diámetro y $10 \mathrm{cms}$. de profundidad; gran molino en forma de paralelepípedo con mortero central de $18 \mathrm{cms}$. de diámetro que ya traspasó todo el bloque y otros poyos de menor tamaño alrededor del anterior. Un hacha de granito verde y tres fragmentos de otras. De sílex hay cinco lascas sin retoques, cuatro láminas retocadas y quince dientes de hoz.

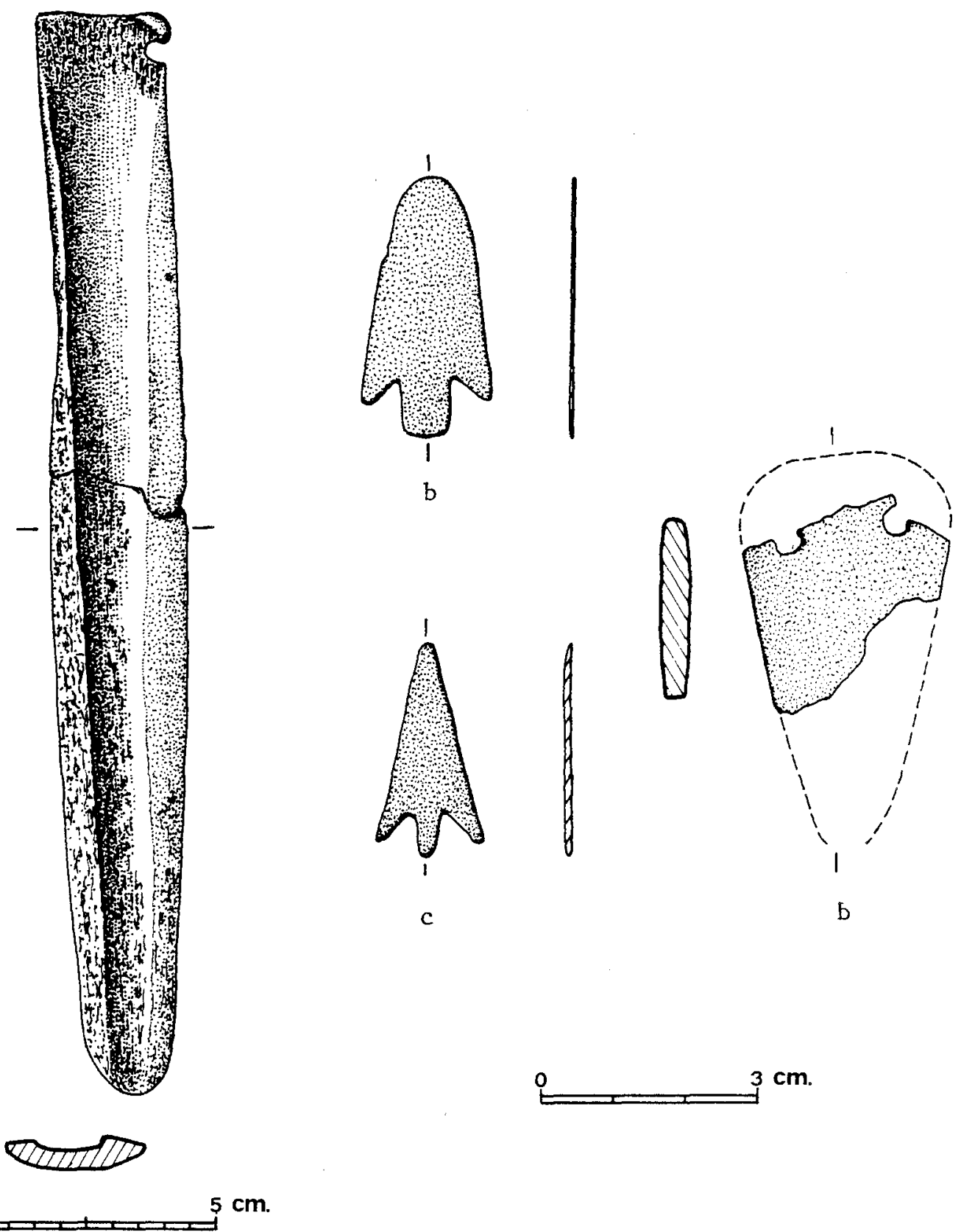


La industria ósea está representada por once punzones y una especie de puñal sobre un hueso largo, bien pulido y con un agujero en el extremo proximal, quizás para un pasador $(21,2 \mathrm{cms} . \times 2,7 \mathrm{cms}$.) (fig. 9 , a).

De metal hay parte de un pequeño puñal triangular con dos orificios para remaches de $0,4 \mathrm{cms}$. de grosor (fig. 9 , d). Dos puntas de flecha con aletas y pedúnculo, probablemente de bronce $(3,65 \times 1,8 \times 0,05$ y $3 \times 1,5 \times 0,1 \mathrm{cms}$., respectivamente) (figs. $9, \mathrm{~b}$ y c). Varios fragmentos muy oxidados de un objeto de difícil identificación, quizás una lezna.

Objetos de adorno son una concha de Littorina neritoides y cinco valvas de Glycimenris glycimeris perforadas.

Por lo que respecta a la Colección de Rescate del Colegio Padre Dehón, de Novelda, se guardan los siguientes materiales: fragmentos pertenecientes a cuatro vasijas de gran tamaño, de pasta regular, coloración marrón claro, marrón rojizo y marrón grisáceo dos de ellas, de superficies espatuladas y muchos fragmentos de cerámicas toscas, algunas con mamelones y color marrón grisáceo.

En cuanto a la industria lítica, hay que señalar en sílex dos lascas atípicas; un raspador fracturado en extremo de lasca laminar de sílex gris oscuro semitraslúcido, frente semicircular, retoque sobreelevado, tendente a abrupto y profundo en el lado fenextro, huellas de uso y desgaste mecánico en la cara inferior; un diente de hoz en sílex blanco. Un molino naviforme de roca caliza; la mitad de otro con cazoleta o mortero central y otros dos menores a su alrededor, aunque originariamente debieron ser cuatro; un canto rodado usado como pieza móvil de molino. Media hacha en granito verde. Nosotros hallamos una completa, que pasó a dicho colegio.

Respecto al material procedente de las excavaciones de M. S. Hernández Pérez, podemos adelantar - gracias a la amabilidad de su excavador - un pequeño esbozo:

La cerámica es muy abundante, correspondiendo a vasos de mediano y gran tamaño, siempre dentro de los tipos establecidos por E. Llobregat (E. LLOBREGAT CONESA: 1966, pp. 129-134). De metal se halló una punta de flecha muy fina y deteriorada, con aletas y pedúnculo, la cual apareció en el corte A-3 y en la zona de contacto entre los niveles I y II; su tipología se asemeja a la de otras que ya hemos citado para el mismo yacimiento. De sílex se recogieron dientes de hoz; completando la industria lítica los numerosos molinos, uno de los cuales se halló «in situ».

En el fondo de la cista sepulcral apareció un anillo de plata de sección circular (M. S. HERNANDEZ PEREZ: 1980, pp. 5-6)

\section{Economía}

En las citadas colecciones particulares no se conservan restos de fauna o vegetales que puedan representar vestigios de actividades económicas. Solamente puede remitirse a las conchas marinas ya señaladas.

Sin embargo, los dientes de hoz y los abundantes molinos, entre ellos esos tan espectaculares por su tamaño y por poseer hoyos o morteros, indican sin duda alguna actividad agrícola de tipo cerealístico. 
Por el contrario, la excavación de 1980 puso al descubierto granos de trigo carbonizado, actualmente en estudio. La fauna terrestre es muy escasa y la marina incluye fragmentos de Cardium edule y Monodonta tumbinata, alguno de ellos usado como adorno.

\section{Cronología}

Para establecer conclusiones de tipo cultural y cronológico sobre El Murón, algunos de sus materiales constituyen una valiosa ayuda. La gran vasija decorada con largos mamelones tiene sus paralelos en cerámicas del Cabezo Redondo (Villena, Alicante) y su cronología debe ser tardía, como la de los cuencos abiertos y con base plana o de tendencia plana. El gran vaso ovoide es de forma poco común, teniendo sus paralelos en otro de la Serra Grossa (Alicante, Alicante). El vaso de perfil hiperboloide debe ser muy tardío, probablemente de un Bronce Tardío. Las puntas de flecha con aletas y pedúnculo no pueden ser anteriores a la mitad del II milenio. El anillo de plata debe también incluirse en un momento a partir de esa fecha, ya que la plata en el País Valenciano, aunque parece estar presente desde el Encolítico, no debió tener un uso extendido hasta la $2{ }^{a}$ mitad del II milenio.

Los materiales muestran, en general, una cronología tardía dentro de la Plena Edad del Bronce, haciendo la salvedad de que otras formas cerámicas del poblado son comunes a todo el Bronce Pleno y, por lo tanto, su cronología es ambigua. Al mismo tiempo, parecen existir contactos con el Valle Alto del Vinalopó y concretamente, con el Cabezo Redondo (Villena). Algunas cerámicas pudieron recordar, por el cuidado de su tratamiento, a las argáricas. Sin embargo, otras son incuestionablemente típicas del Bronce Valenciano.

Por todo ello, nos atrevemos a aventurar la hipótesis de que El Murón vivió el período álgido de su existencia en la segunda mitad del II milenio, quedando fijado su momento final por la ausencia de cerámicas típicas del Horizonte Gogotas I, y que sí encontramos en el cercano poblado de El Tabayá (Aspe, Alicante). Queda por establecer el momento inicial de su existencia, lo cual puede establecerse en el curso de futuras campañas de excavaciones.

Por lo que respecta a su ambiente cultural, podemos insertarlo plenamente en el Bronce Valenciano, pero con ligeras influencias muy atenuadas de un momento avanzado del Algar, porque probablemente no se recibieron directamente, sino a través de la zona de Villena y su potente foco del Cabezo Redondo. Los futuros trabajos de campo podrán reforzar o desmentir esta hipótesis.

\section{LA PEDRERA O PORTIXOL}

El yacimiento está en un cerro adelantado de la Sierra de la Pedrera o El Portixol, en el término municipal de Monforte del Cid (Alicante). Coordenadas geográficas: $38^{\circ} 21^{\prime} 53^{\prime \prime}$ lat. N. y $0^{\circ} 41^{\prime} 14^{\prime \prime}$ long. W. del meridiano de Greenwich.

La Pedrera forma parte de un arco de sierras (La Horna, la Sierra de Aspe, El Tabayá, Las Lomas de la Cañada, La Pedrera y la Sierra de las Aguilas) que enmarcan por el Sur al Valle Medio del Vinalopó. 
El cerro posee dos crestas rocosas separadas por un collado. Actualmente constituye coto de caza y está sembrado de madrigueras de conejos, que sacan a la superficie gran cantidad de piezas arqueológicas, cenizas, huesos, etc. Ha sido prospectado en diversas ocasiones por V. Gómez García y los Grupos de Rescate que él dirige, gracias a una autorización de los propietarios del coto. Durante nuestra visita nos fue impedido su acceso y suponemos que otro tanto ocurrirá con los coleccionistas, por lo que el yacimiento en este sentido está a salvo. No así de las citadas madrigueras (GRUPO DE RESCATE 688: 1978, p. 63).

Parece existir en la parte alta un considerable relleno, pero no se ve aflorar resto alguno de construcciones.

Los materiales procedentes de este yacimiento en la colección de M. Romero Iñesta son: un vaso de fondo convexo y paredes rectas entrantes con cuatro mamelones aplastados o asas de lengüeta, debajo de una de las cuales hay un orificio, de pasta cuidada, paredes notablemente finas, color marrón claro y superficie pulimentada $(26,8 \mathrm{cms}$. diám. máx. y $23 \mathrm{cms}$. alt.) (fig. 10 , b). Un fragmento de cerámica de pasta regular con ligero bruñido y color gris en la cara interna y superficie exterior marrón amarillenta; en la superficie externa tiene decoración incisa e impresa con tema semejante a una espiga (fig. 10, f). Fragmento de vasija de fondo plano de gran tamaño, pasta cuidada, color marrón oscuro y pulimentada. Otro fragmento de fondo plano, de cerámica grosera. Dos fragmentos de bordes con mamelones.

La industria lítica incluye treinta y siete lascas y láminas de sílex blanco, melado, marrón y gris, algunas con retoques de uso y otras son dientes de hoz a medio trabajar; dieciocho dientes de hoz. De hueso un punzón. En cuanto al metal hay que mencionar un fragmento de punzón de sección cilíndrica; un trozo informe, restos de una hoja doblada, quizás chatarra para volver a ser fundida; $y$, asociado a ellos, parte de un molde prismático con cinco canales, dos de ellos de sección cuadrada y tres de sección triangular, que debieron servir para fundir barritas, aptas luego para diversos fines (fig. 10, e). Como adorno hay un fragmento de pequeño brazalete de pectúnculo; cinco valvas de pectúnculo (Glycimeris sp.) y tres de Cardium edule todas perforadas. Además, dos valvas más de pectúnculo y columbella rústica sin perforar.

La Colección Rescate posee un cuenco semiesférico de pasta regular, color irregular con intenso espatulado $(12,8 \mathrm{cms}$. diám. y $7 \mathrm{cms}$. alt.) (fig. $10, \mathrm{c})$. Vasija lenticular de fondo plano, de pasta cuidada, color marrón oscuro a negro y bruñida $(14,6 \mathrm{cms}$. diám. máx. y 8,6 cm. alt.) (fig. 10, d). Medio vaso paraboloide con un mamelón cerca del borde, que probablemente se correspondía, según es normal, con otro en el lado opuesto, pasta poco cuidada, superficie negruzca mal alisada (14,7 cms. diám. máx. y 17,1 cms. alt.) (fig. 10, a). Parte de una vasija de la que se conserva el fondo y parte de las paredes, siendo su forma probablemente la đe un cuenco semiesférico u otra forma similar, pasta poco cuidada de color gris-marrón oscuro. Una pesa de telar cilíndrica con un orificio asimétrico, de pasta grisácea casi blanca y de ligero peso, probablemente con alto contenido de ceniza.

La industria lítica en esta colección está representada por: dos fragmentos de hachas pulimentadas; media piedra afiladera, que originariamente debió medir $11 \times 3,1 \mathrm{cms}$; una piedra de afilar con dos ranuras, probablemente para 

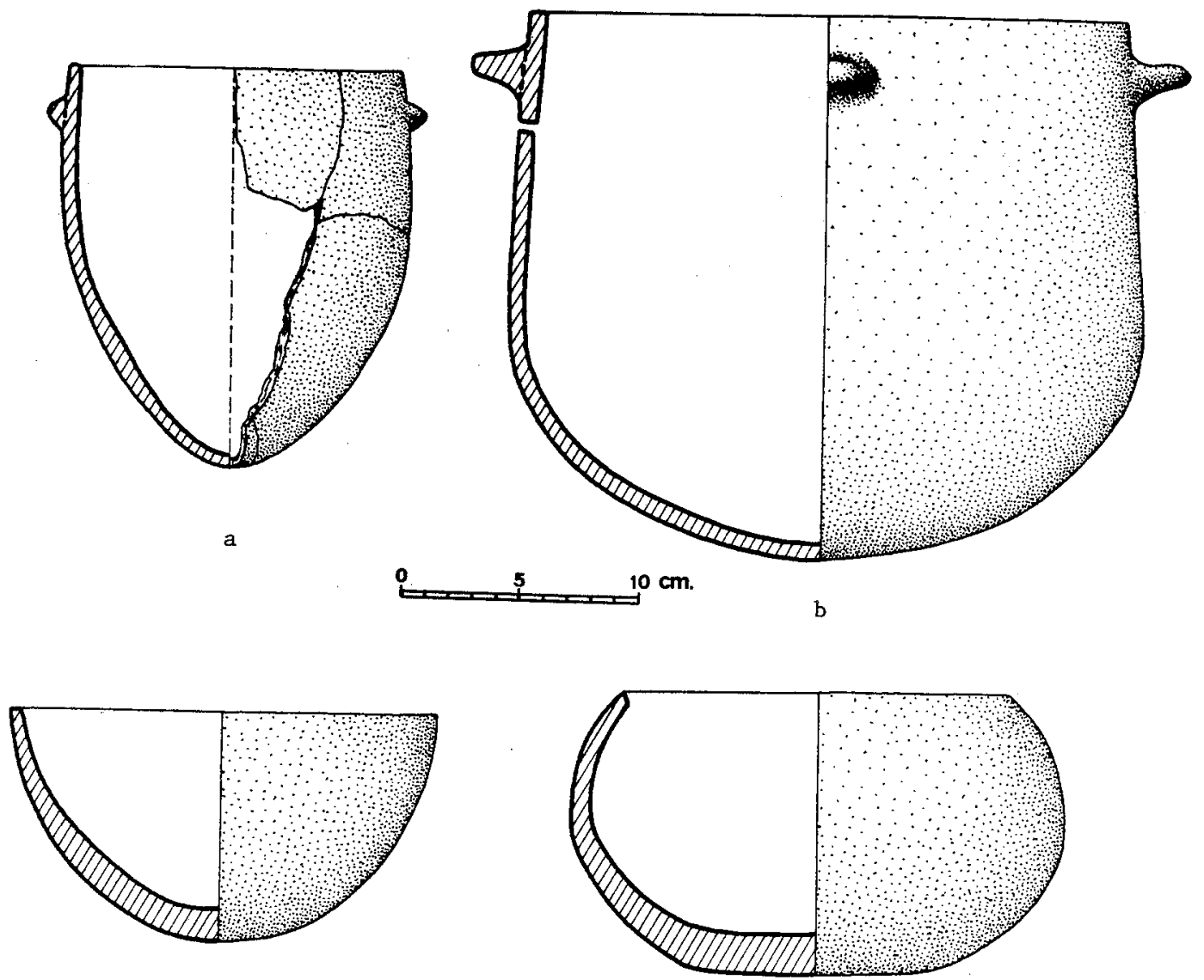

c
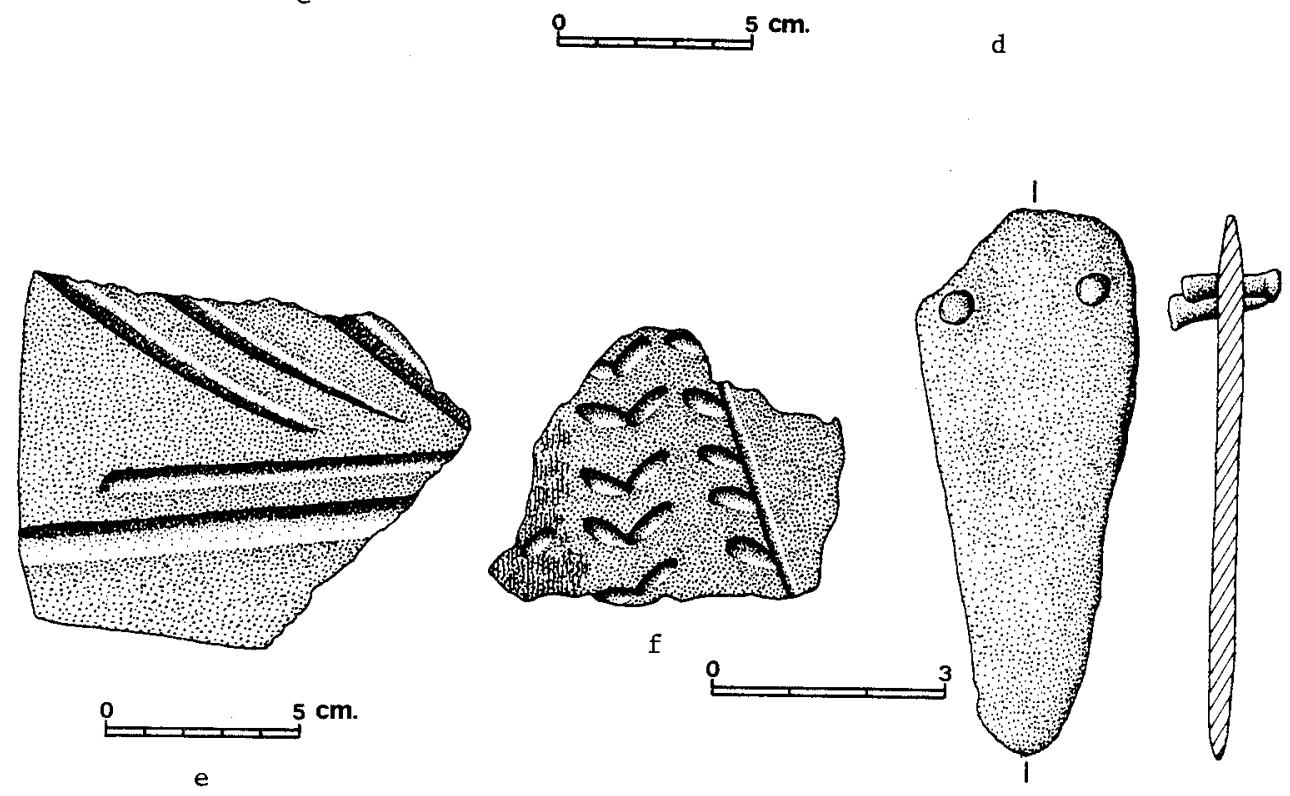

g

10. La Pedrera o Portixol (Monforte del Cid) 
punzones; varios pequeños cantos rodados; un esferoide de caliza con un pequeño agujero. De sílex en distintos colores hay: una lámina prismática con retoques de uso en ambos filos; una sierra sobre lámina prismática; tres fragmentos de láminas, una retocada; doce dientes de hoz en distintos tamaños y sílex; veintiuna lascas sin retocar.

El metal incluye un puñalito triangular con dos remaches $(7,1 \times 2,9 \times 0,3$ cms.) (fig. $10, \mathrm{~g}$ ) y un fragmento de otro.

Como adornos han de incluirse cinco conchas de Glycimeris sp. perforadas y otra sin agujero.

Además de las citadas conchas, apareció un diente de tiburón y otro de animal indeterminado; así como numerosos fragmentos de huesos de herbívoros, entre los que se pueden identificar algunos de ciervo (Cervus elaphus), quizás bóvido, caballo y ovicápridos. También una gran cantidad de caracoles terrestres, sobre todo el Iberus alonencis.

Además, debe considerarse indiscutible la presencia de actividad metalúrgica local.

En el Portixol, o la Pedrera, tenemos un Bronce Pleno inserto en la Cultura del Bronce Valenciano. Pero parecen observarse, además, algunas influencias del área argárica durante la fase Plena del Bronce y, también, unas influencias de la Meseta ya en un Bronce Final, puestas de manifiesto en ese fragmento de cerámica decorada, con paralelos en el Bronce Final del Círculo Cogotas y, más cerca, en el Cabezo Redondo de Villena. Por lo tanto, la duración de su poblamiento debió ser larga, prolongándose como mínimo hasta finales del segundo milenio a. C.

\section{PUNTAL DE BARTOLO}

\section{Situación}

El Puntal de Bartolo es un espolón que arranca del Cerro de la Mola hacia el NW. Se levanta a unos 440 mts. s.n.m. en la margen derecha del río Vinalopó, a $500 \mathrm{mts}$. al NW. del Castillo de Luna, en el término municipal de Novelda (Alicante). Coordenadas geográficas: $38^{\circ} 24^{\prime} 44^{\prime \prime}$ lat. N. y $0^{\circ} 47^{\prime} 23^{\prime \prime}$ long. W. del meridiano de Greenwich.

En su cima y laderas debió de existir un importante poblado de la Edad del Bronce, hoy parcialmente desaparecido, por una cantera de mármol, que paulatinamente va haciendo desaparecer el Puntal. Y lo que no ha sido arrasado por la cantera, está siendo desbaratado por los clandestinos.

\section{Historia de la investigación}

Prospectado por M. Romero Iñesta y algún otro aficionado de Novelda, fue excavado parcialmente por el primero, quien descubrió una vivienda destruí- 
da por el fuego, la cual contenía un riquísimo ajuar. De las características de ésta no queda constancia. Ha sido visitado por el Grupo de Rescate $n .{ }^{\circ} 688$, que lo dio a conocer (GRUPO DE RESCATE 688: 1978, p. 61) aunque denominándolo «Mola II» por desconocer su verdadero nombre. Nosotros hemos visitado el yacimiento en 1977 y 1978, al tiempo que estudiábamos materiales en colecciones particulares.

\section{El poblado y sus estructuras constitutivas}

El poblado debió ocupar especialmente la parte superior de la vertiente SW., al abrigo de la cresta rocosa de la cima, que lo protegería de los vientos del Norte, quedando así de espaldas al río. Allí las rebuscas de clandestinos han revuelto la mayor parte del relleno arqueológico, si bien los hallazgos continúan ladera bajo y también por la vertiente opuesta. De las viviendas sólo quedan algunas alineaciones de piedras, de difícil interpretación por las continuas remociones.

\section{Materiales muebles}

\subsection{De origen indeterminado.}

La Colección Rescate del Colegio Padre Dehón guarda un cuenco en forma de casquete esférico, de pasta marrón grisácea regular, superficie alisada (16,5 cms. diámetro, 6,5 cms. alto), hallado en la ladera SW. Además, hay otros fragmentos de cerámica; un molino naviforme; un diente de hoz; dos lascas de sílex blanco, desecho de talla; y una lasca de sílex melado con retoques de uso.

La Colección de M. Romero Iñesta guarda los siguientes materiales de procedencia incierta: vaso de tendencia elipsoide con tres mamelones cerca del borde, pasta cuidada, color rojizo y espatulados (diámetro máximo $32,2 \mathrm{cms}$., alto $2,95 \mathrm{cms}$.) (fig. 11, a). Vasija de fondo paraboloide y estrecho cuello hiperboloide, pasta irregular, color beige-rojizo-grisáceo, superficie ligeramente pulimentada (34 cms. diám. máx., 30,1 cms. alto) (fig. 11, b). Vasija similar, aunque con el cuello menor, de pasta cuidada, color beige y superficie pulimentada exterior e interiormente (33 cms. diám. máx., $28 \mathrm{cms}$. alto) (fig. 12, a). Dos fragmentos de pasta grosera y un gran mamelón junto al borde. Una pesa de telar cilíndrica con orificio central.

De sílex hay tres núcleos reutilizados como mano de mortero o percutor, de color blanco melado y blanco; doce lascas de sílex marrón oscuro, melado, blanco, gris y rojo, algunas con retoques de uso; nueve dientes de hoz, de sílex rojo (una), blanco (cuatro), melado (tres) y gris (una); un esferoide de sílex muy desgastado. Dos molinos naviformes de caliza. Cuatro manos de molino o percutores, uno discoidal, en caliza y tres cilíndricos. Un esferoide de granito, con señales de uso. Un canto rodado con señales de fuego. Medio brazalete de arquero de una especie de arenisca gris muy dura, con un orificio en el extremo.

El metal está representado por dos fragmentos de punzón en cobre o bronce, de sección circular; una punta de lanza o puñal romboidal de cobre, con un 
doblez por un lado $(10,8 \times 2,5 \times 0,1 \mathrm{cms}$.) (fig. $19, \mathrm{~g})$; un lingote de cobre o bronce en forma almendrada $(2,2 \times 1,6 \times 0,3 \mathrm{cms}$.)

Cinco valvas de Glycimeris sp., dos de ellas perforadas; siete conchas de Columbella rústica, dos de Conus mediterraneus, una de Cyoraea sp. y dos valvas de Cardium edule, todas ellas perforadas; y una valva de Ostrea sp. sin perforar.

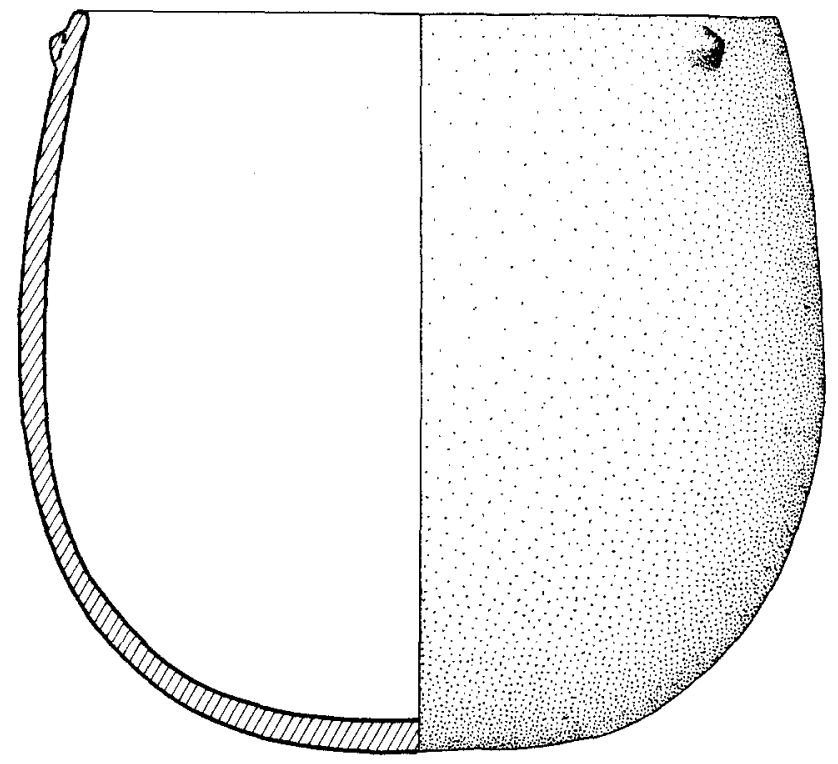

a

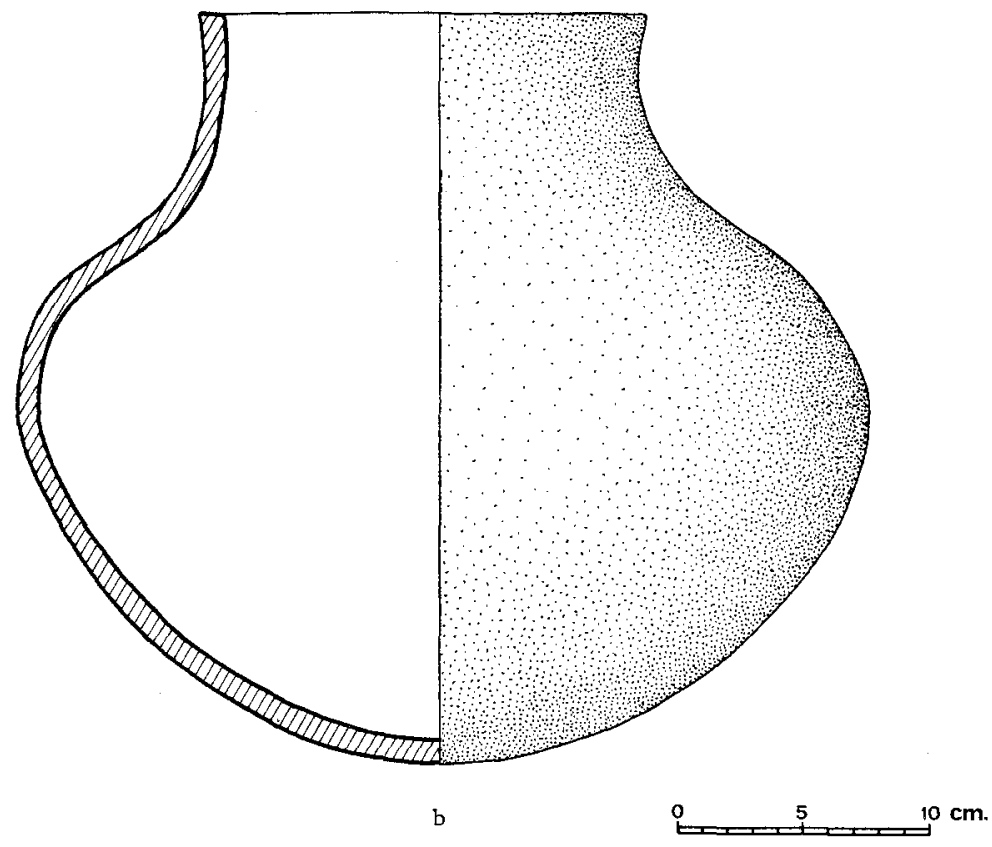

11. Puntal de Bartolo (Novelda) 


\subsection{De una vivienda}

La vivienda excavada por $\mathrm{M}$. Romero Iñesta suministró veinticinco vasijas completas y el fondo de otra: $1 .^{\circ}$ ) Vaso de tendencia esférica con borde recto y cuatro asas de cinta horizontales cerca del borde, pasta regular, color beige al exterior y negruzco al interior, superficie irregular espatulada $(17,5 \mathrm{cms}$. diám. máx. y $16 \mathrm{cms}$. alt.) (fig. 12, b). $2 .^{\circ}$ ) Vasija de tendencia semielipsoide, color beige claro al grisáceo, superficie irregular $(18,6 \mathrm{cms}$. diám. máx. y $14 \mathrm{cms}$. alt.) (fig. 15 , a). $3 .^{\circ}$ ) Vasija con tendencia a carena media, borde engrosado al exterior, pasta cuidada, color marrón grisáceo, superficie pulimentada $(23,2 \mathrm{cms}$. diám. máx. y $18 \mathrm{cms}$. alt.) (fig. 13, a) $4 .^{\circ}$ ) Vasija de tendencia lenticular con cuello exvasado, pasta cuidada, color marrón negruzco, superficie pulimentada (25,5 cms. diám. máx. y $19 \mathrm{cms}$. alt.) (fig. $\left.13, \mathrm{~d}) .5 .^{\circ}\right)$ Cuenco de tendencia semielipsoide asimétrico con asa de cinta en el borde, pasta regular, color beige, superficie pulimentada $\left(13,4 \mathrm{cms}\right.$. diám. máx. y $9 \mathrm{cms}$. alt.) (fig. 13, b). 6. ${ }^{\circ}$ ) Cuenco semiesférico de bordes entrantes, pasta regular, color negruzco y superficie pulimentada $\left(17,3 \mathrm{cms}\right.$. diám. máx. y $9 \mathrm{cms}$. alt.) (fig. 13 , e) $\left.7 .{ }^{\circ}\right)$ Cuenco similar al $\mathrm{n} .^{\circ} 5$, en forma y tratamientos $(14,5 \mathrm{cms}$. diám. máx. y $9,4 \mathrm{cms}$. alt.) (fig. $13, \mathrm{c}$ ). $8 .^{\circ}$ ) Cuenco de tendencia semiesférica con bordes entrantes, asa de lengüeta vertical junto al borde, pasta regular, color beige, superficie pulimentada $\left(17,2 \mathrm{cms}\right.$. diám. máx. y $11 \mathrm{cms}$. alt.) (fig. 14, a). 9. ${ }^{\circ}$ ) Cuenco de tendencia paraboloide de borde entrante, pasta cuidada, color beige y superficie bien bruñida (12 cms. diám. máx. y 6,6 cms. alt.) (fig. 13, f). 10. ${ }^{\circ}$ ) Cuenco semielipsoide, pasta cuidada, marrón grisáceo y superficie pulimentada $(8 \mathrm{cms}$. diám. máx. y $5,5 \mathrm{cms}$. alt.) (fig. $14, \mathrm{c}$ ), fue hallado junto con granos de trigo carbonizados sobre los restos de una capaza carbonizada de esparto; tanto el trigo como el vaso estarían en el interior del capazo, siendo probable que aquél sirviera para extraer el grano $11 .^{\circ}$ ) Cuenco semiesférico de boca abierta, pasta buena, color rojizo, restos de pulimento ( $11,2 \mathrm{cms}$, diám. y 5,6 cms. alt.) (fig. 14, e). $12 .^{\circ}$ ) Cuenco semiesférico, pasta cuidada, superficie color beige y pulimentada (14,2 cms. diám. y 6,2 cms. alt.) (fig. $14, \mathrm{~d}) .13 .^{\circ}$ ) Cuenco similar al anterior, pero con señales de fuego ( $15 \mathrm{cms}$. diám. y $7,4 \mathrm{cms}$. alt.) (fig. $\left.14, \mathrm{~b}) .14 .^{\circ}\right)$ Cuenco de boca muy abierta, casi cónico invertido, pasta cuidada, superficie beige y pulimentada $(27,2 \mathrm{cms}$. diám. y $10,2 \mathrm{cms}$. alt.) (fig. $\left.14, \mathrm{f}) .150^{\circ}\right)$ Vaso con carena alta y borde exvasado, pasta cuidada, superficie marrón-marrón oscura y pulimentada $(15,6 \mathrm{cms}$. diámetro y $14 \mathrm{cms}$. alt.) (fig. $\left.15, \mathrm{c}) .16 .^{\circ}\right)$ Vaso de tendencias elipsoides asimétrico, pasta regular, superficie marrón claro y espatulada (18,6 cms. diám. máx. y 15,4 cms. alt.) (fig. 15, a). $\left.17 .^{\circ}\right)$ Cuenco semiesférico con asa de cinta cerca del borde, pasta cuidada, superficie color beige y pulimentada (14,8 cms. diám. y 9,6 cms. alt.) (fig. 15, d). $18 .^{\circ}$ ) Vaso elipsoide de borde exvasado con cuatro mamelones cerca del borde, pasta grosera, superficie de color irregular del rojizo al negruzco y espatulada $(19,8 \mathrm{cms}$. diám. máx. y $21 \mathrm{cms}$. alt.) (fig. $\left.15, b) .19 .^{\circ}\right)$ Vaso asimétrico, de tendencia semiesférica con ligero cuello exvasado y asa de cinta, pasta cuidada, color marrón-marrón oscuro y algo pulimentada (16,2 cms. diám. máx. y $11,4 \mathrm{cms}$. alt.) (fig. 15, e). $20 .^{\circ}$ ) Vaso con carena alta y borde exvasado, pasta cuidada, superficie negruzca espatulada con ligero pulimento ( $36 \mathrm{cms}$. diám. máx. y $32 \mathrm{cms}$. alt.) (fig. 16, b). 21. ${ }^{\circ}$ ) Vaso len- 
ticular con cuello exvasado, pasta cuidada, color rojizo y pulimentada $(27 \mathrm{cms}$. diám. máx. y $15 \mathrm{cms}$. alt.) (fig. 16, a). $22 .^{\circ}$ ) Vasija de tendencia esférica con cuello exvasado, pasta cuidada, color beige-gris y alisada $(49 \mathrm{cms}$. diám. máx. y 40 cms. alt.) (fig. 17, a) $.23 .^{\circ}$ ) Vasija similar a la anterior, aunque de cierta tendencia paraboloide y la boca más abierta, pasta cuidada, superficie color beige y pulimentada $(52,5 \mathrm{cms}$. diám. máx. y $41 \mathrm{cms}$. alt.) (fig. $\left.17, \mathrm{~b}) .24 .^{\circ}\right)$ Vasija similar a la anterior, con el cuello menor, cuatro pares de mamelones simétricamente re-

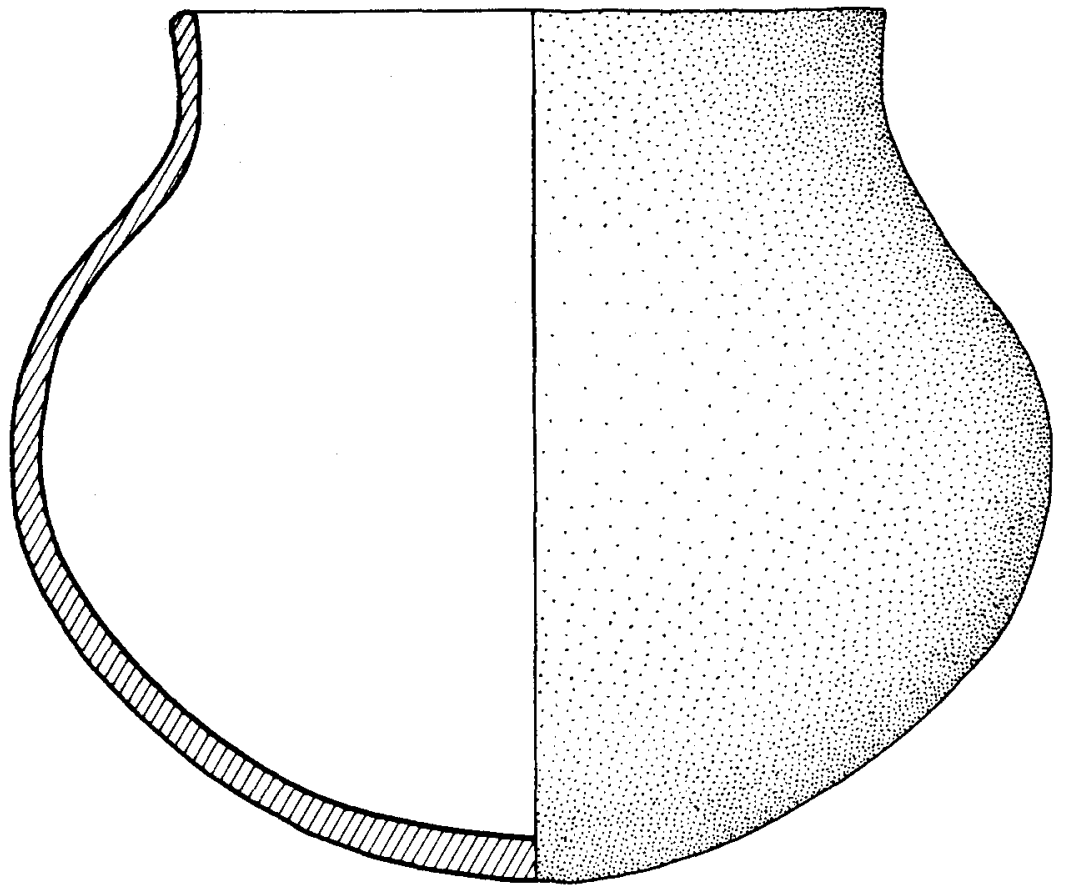

a
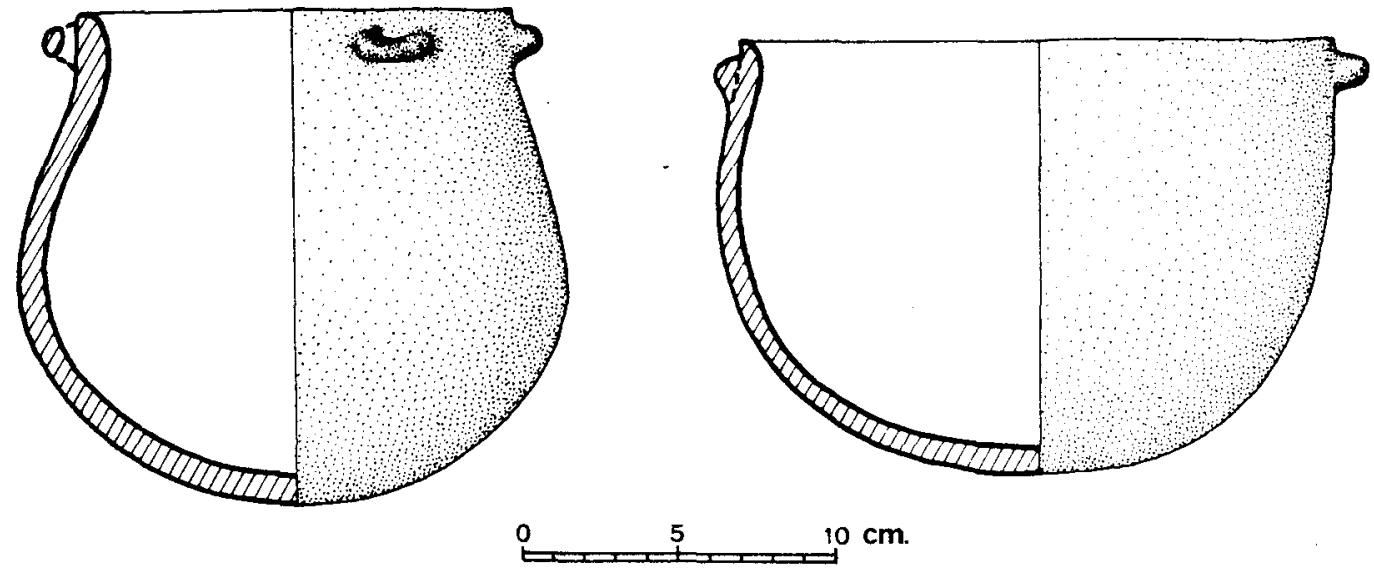

b

12. Puntal de Bartolo (Novelda) 

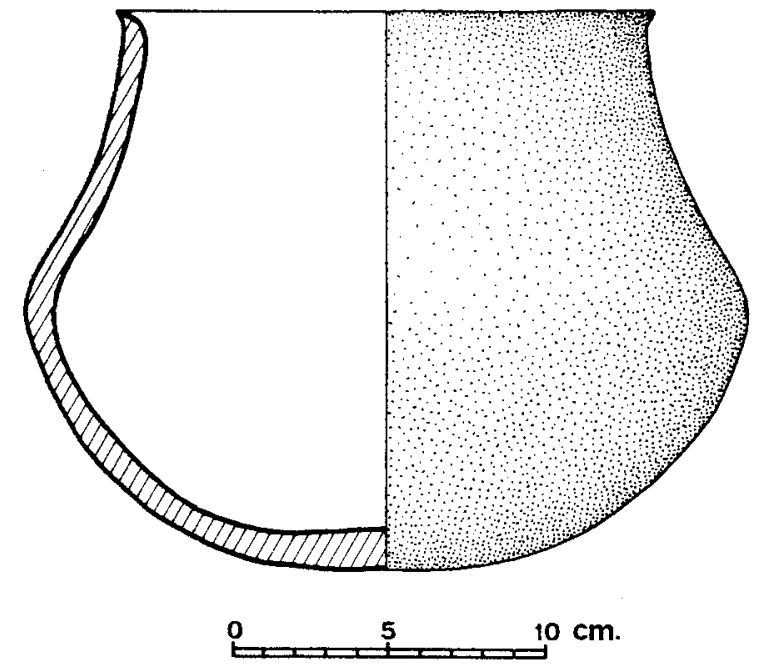

a
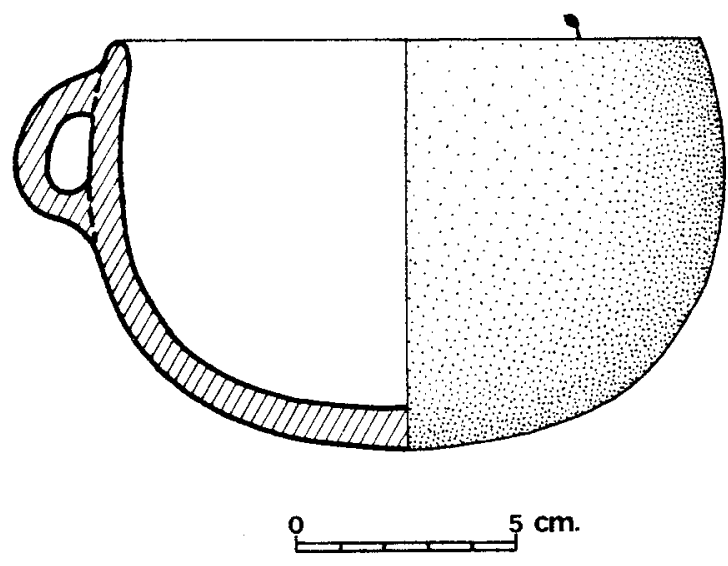

c

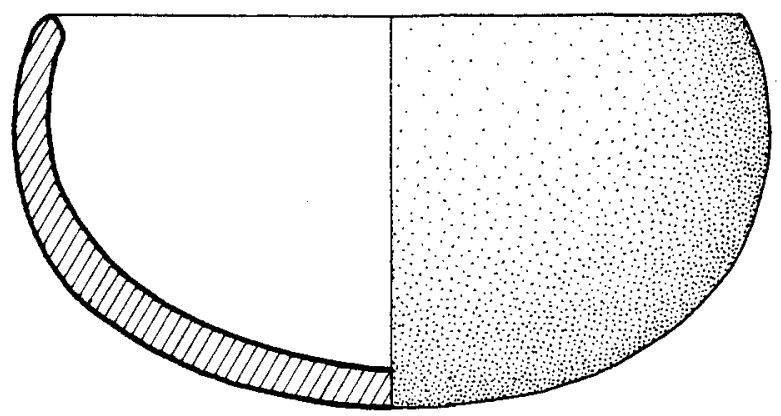

e

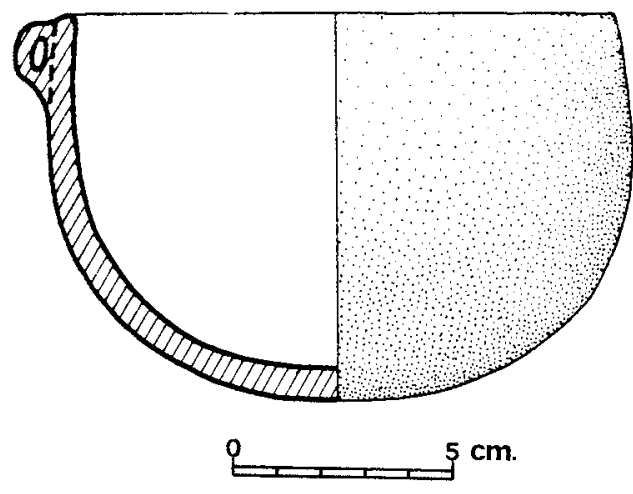

b
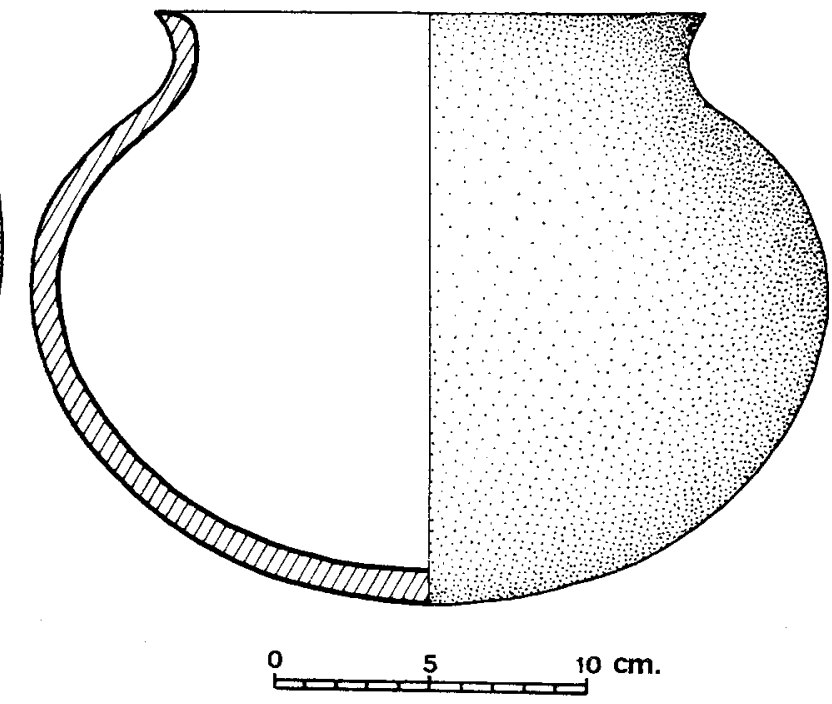

d
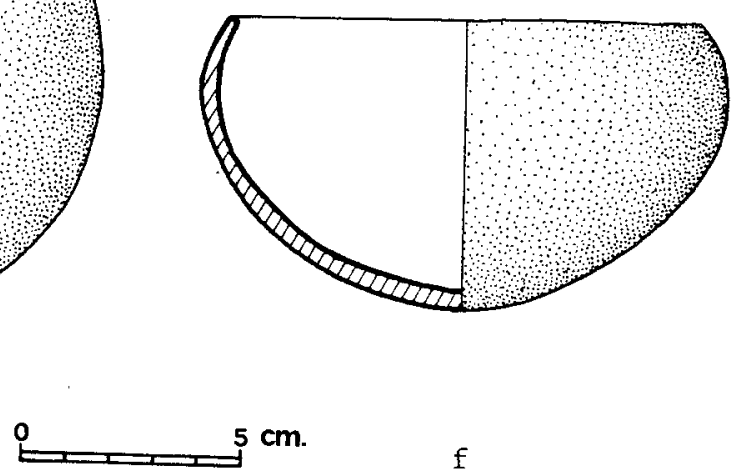

13. Puntal de Bartolo (Novelda) 


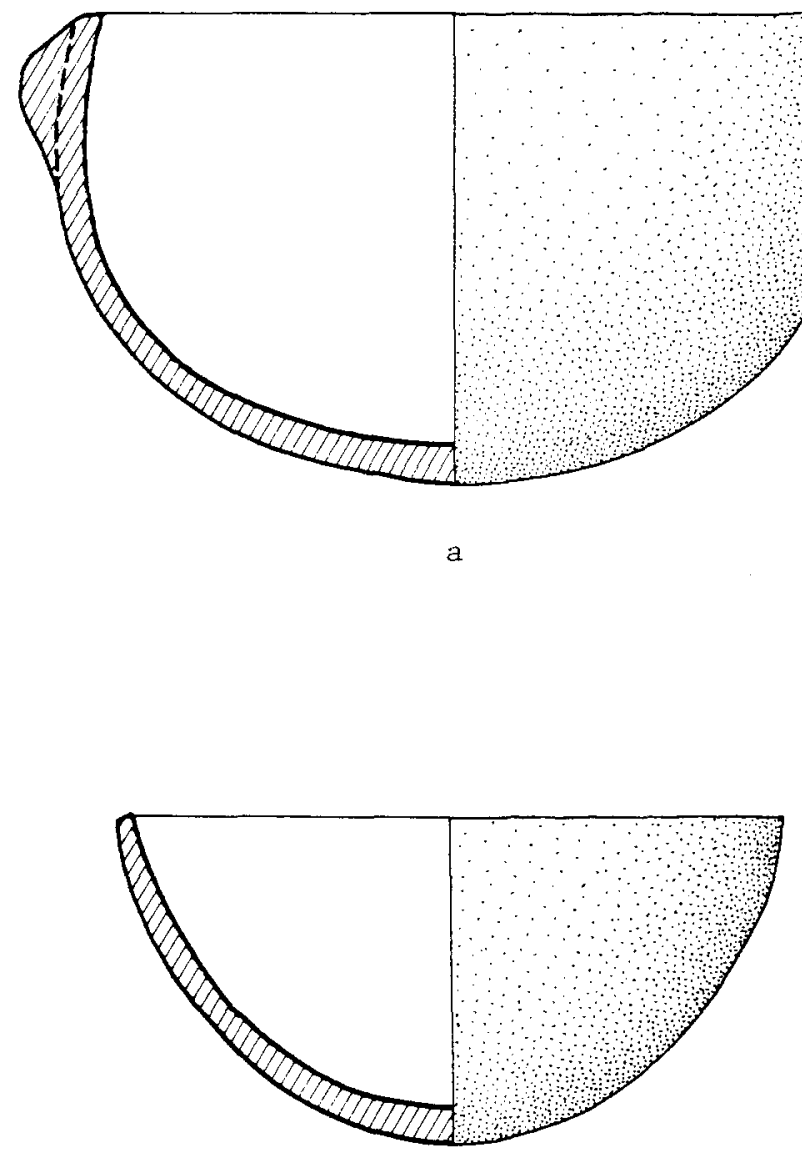

b

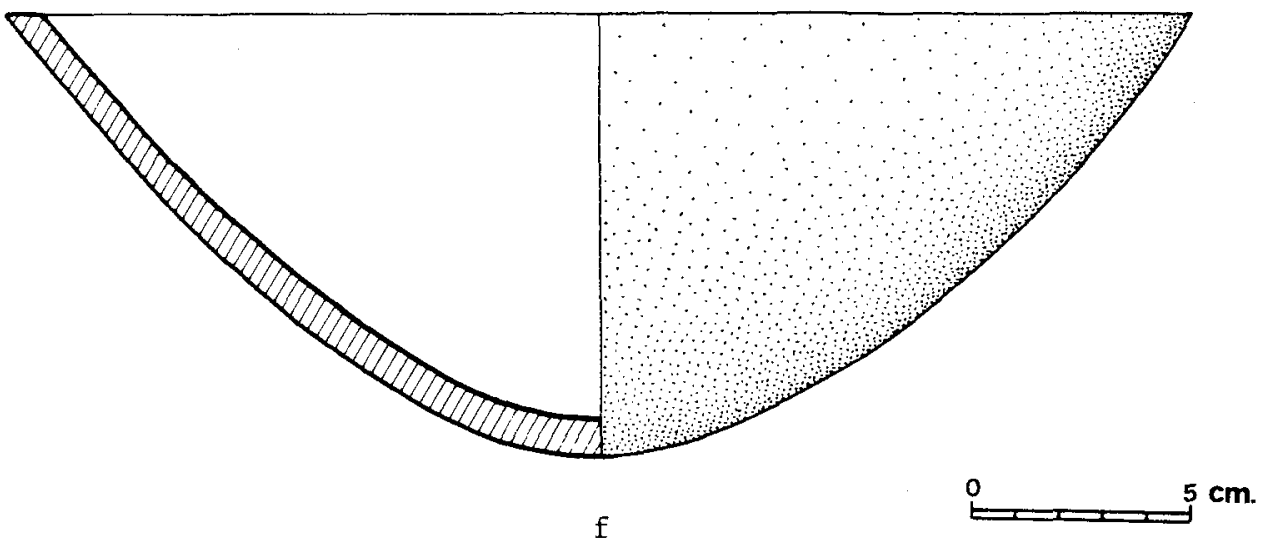

14. Puntal de Bartolo (Novelda)

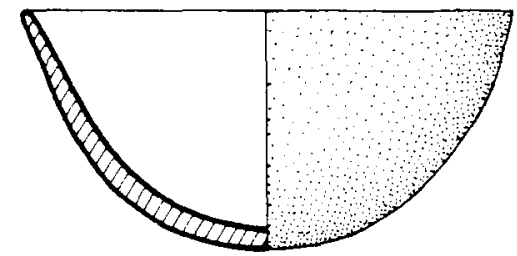

e 

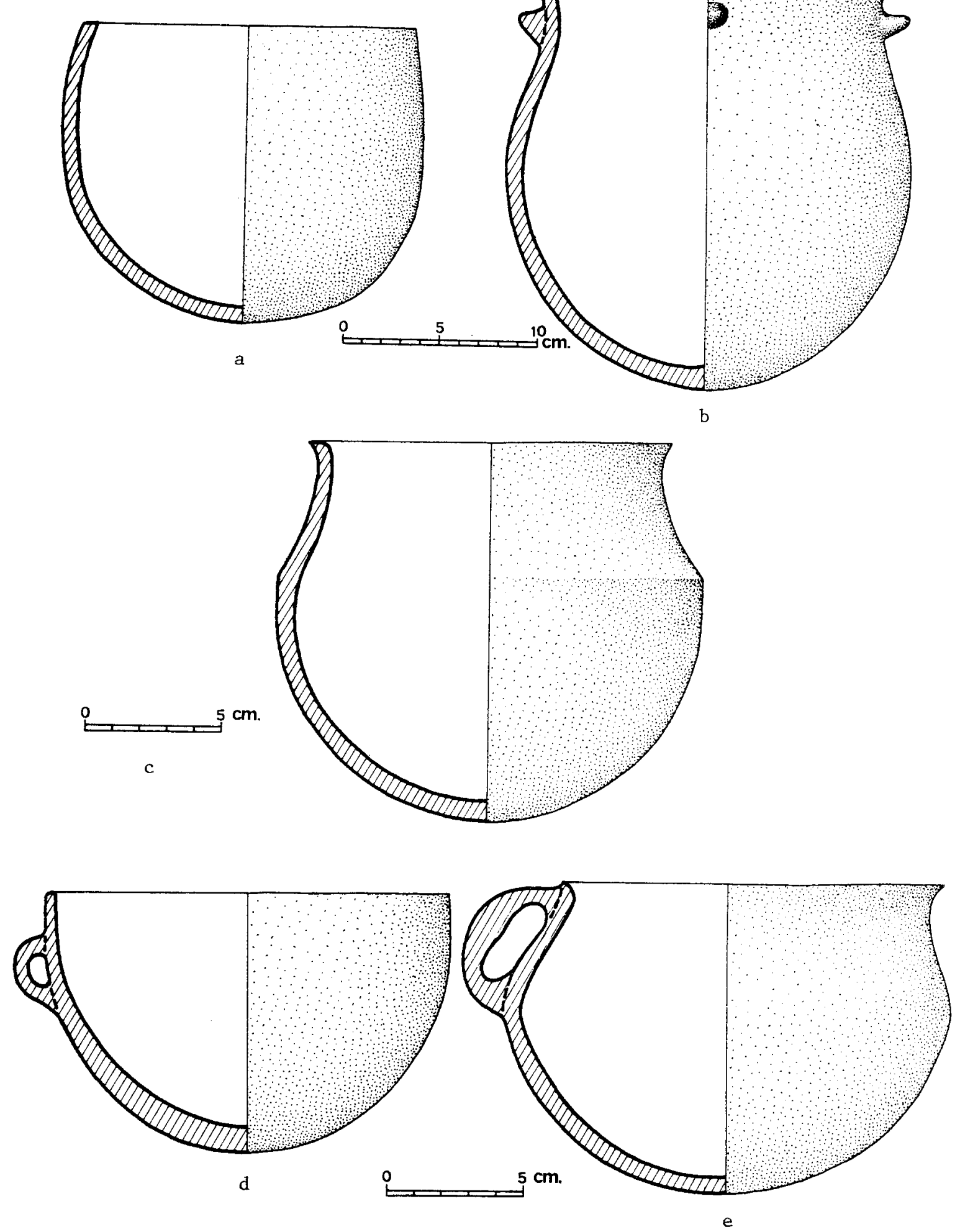

15. Puntal de Bartolo (Novelda) 

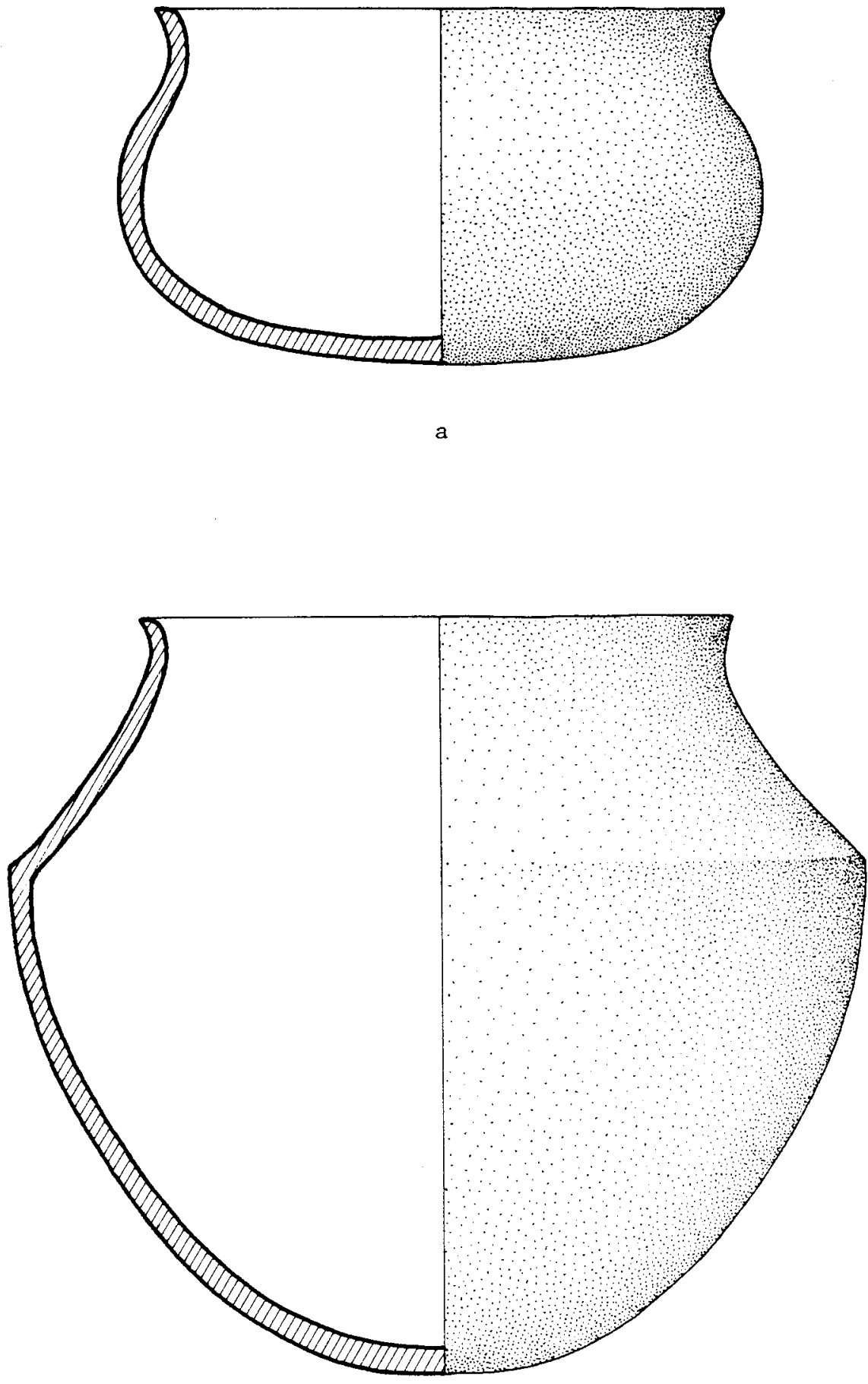

b

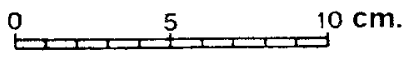

16. Puntal de Bartolo (Novelda) 

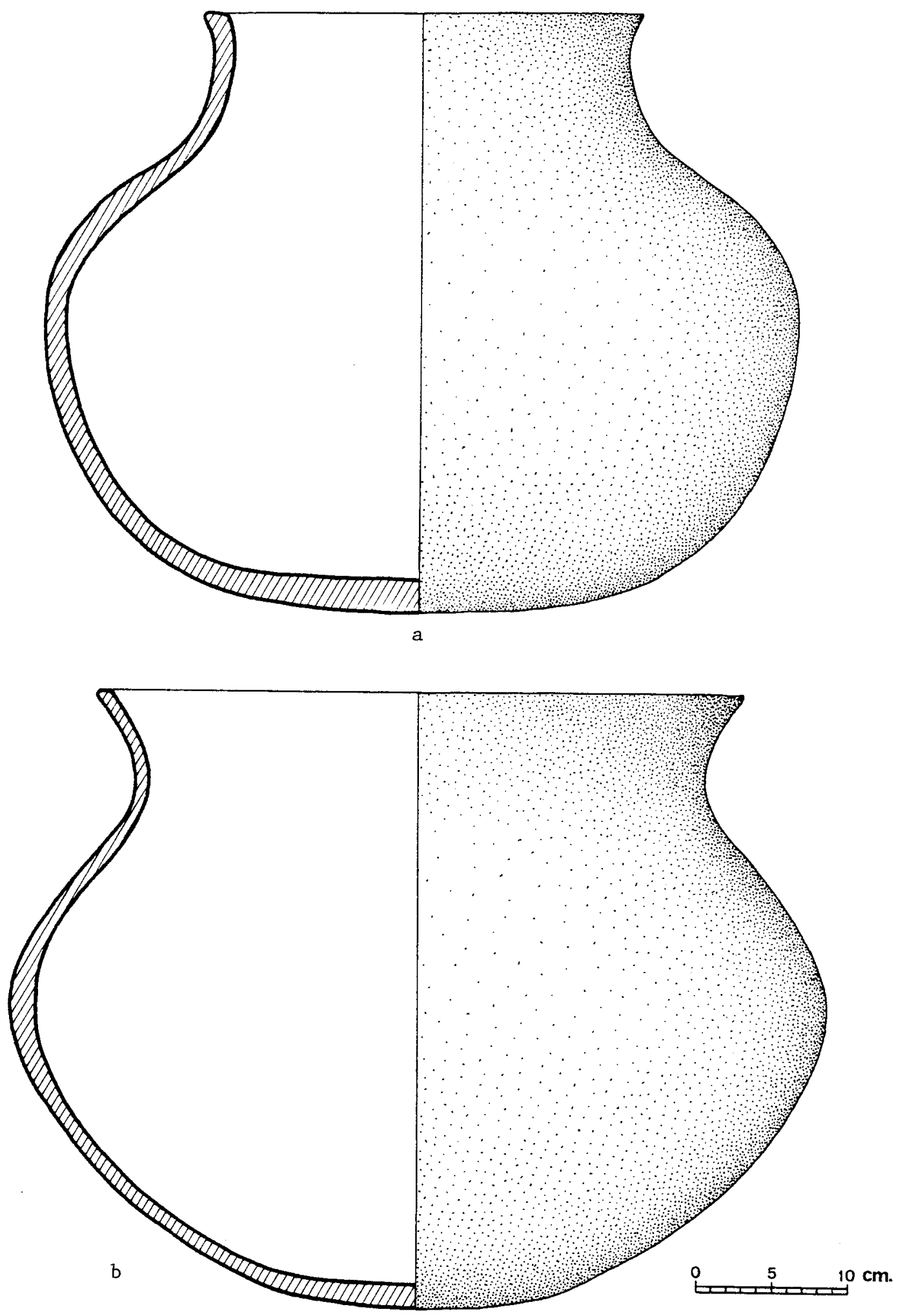

17. Puntal de Bartolo (Novelda) 


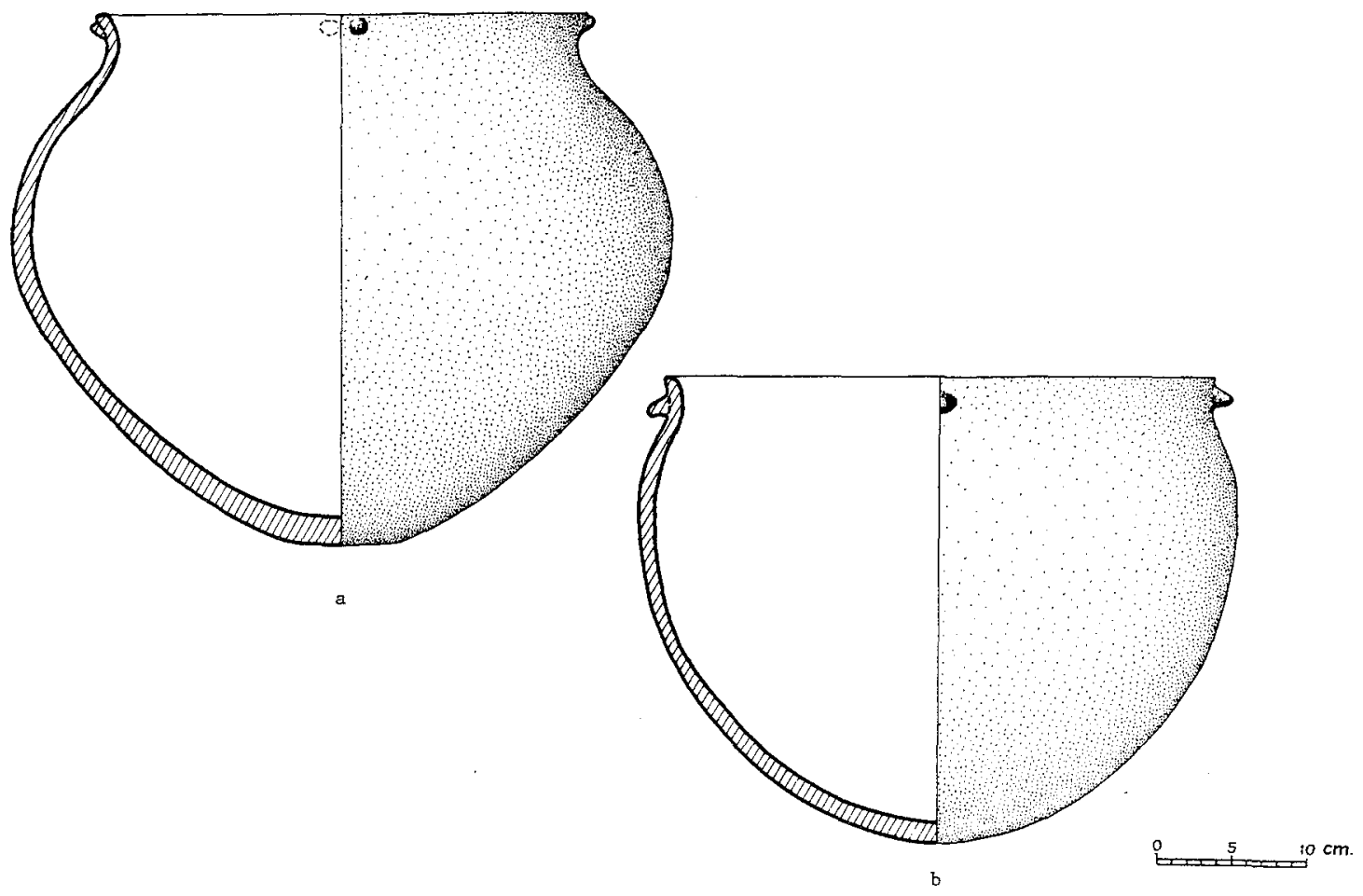

18. Puntal de Bartolo (Novelda)

partidos y fondo ligeramente plano, tratamiento igual $(44 \mathrm{cms}$. diám. máx. y 36 cms. alt.) (fig. 18, a). $25 .^{\circ}$ ) Vasija de tendencia paraboloide con la boca más abierta que la 24 y cuatro mamelones aplanados junto al borde, pasta grosera, superficie de coloración irregular del rojizo al negruzco y espatulada $(40 \mathrm{cms}$. diám. máx. y $31,5 \mathrm{cms}$. alt.) (fig. $18, \mathrm{~b}$ ). $26 .^{\circ}$ ) Varios fragmentos de una vasija de fondo convexo y forma indeterminable, aunque de $30 \mathrm{cms}$. de diámetro en la panza; posee un cordón liso que rodea la parte inferior del vaso, y en la base hay un botón cilíndrico de $2,3 \mathrm{cms}$. de ancho y $0,6 \mathrm{cms}$. de alto; la pasta es regular y la superficie marrón oscuro al negro; fue hallada entre los restos de otro capazo de esparto con trigo, carbonizados, como en el cuenco n. ${ }^{\circ} 10$.

De piedra hay un molino naviforme en piedra volcánica porosa y negra, con su pieza móvil en basalto. De sílex un diente de hoz y dos fragmentos atípi$\cos$.

Una valva de Glycimeris sp. agujereada en el natis.

El metal está representado por una laminilla de $2,7 \times 0,5 \times 0,22 \mathrm{cms}$. en cobre o bronce. De lo mismo son seis puntas de flecha, tres de ella de tipo Palmela, una con aletas totalmente desarrolladas, otra con pequeñas aletas y una con aletas apenas indicadas. Están muy atacadas por el óxido, de forma que en algunas es difícil averiguar sus proporciones originales (fig. 19 a-f). 

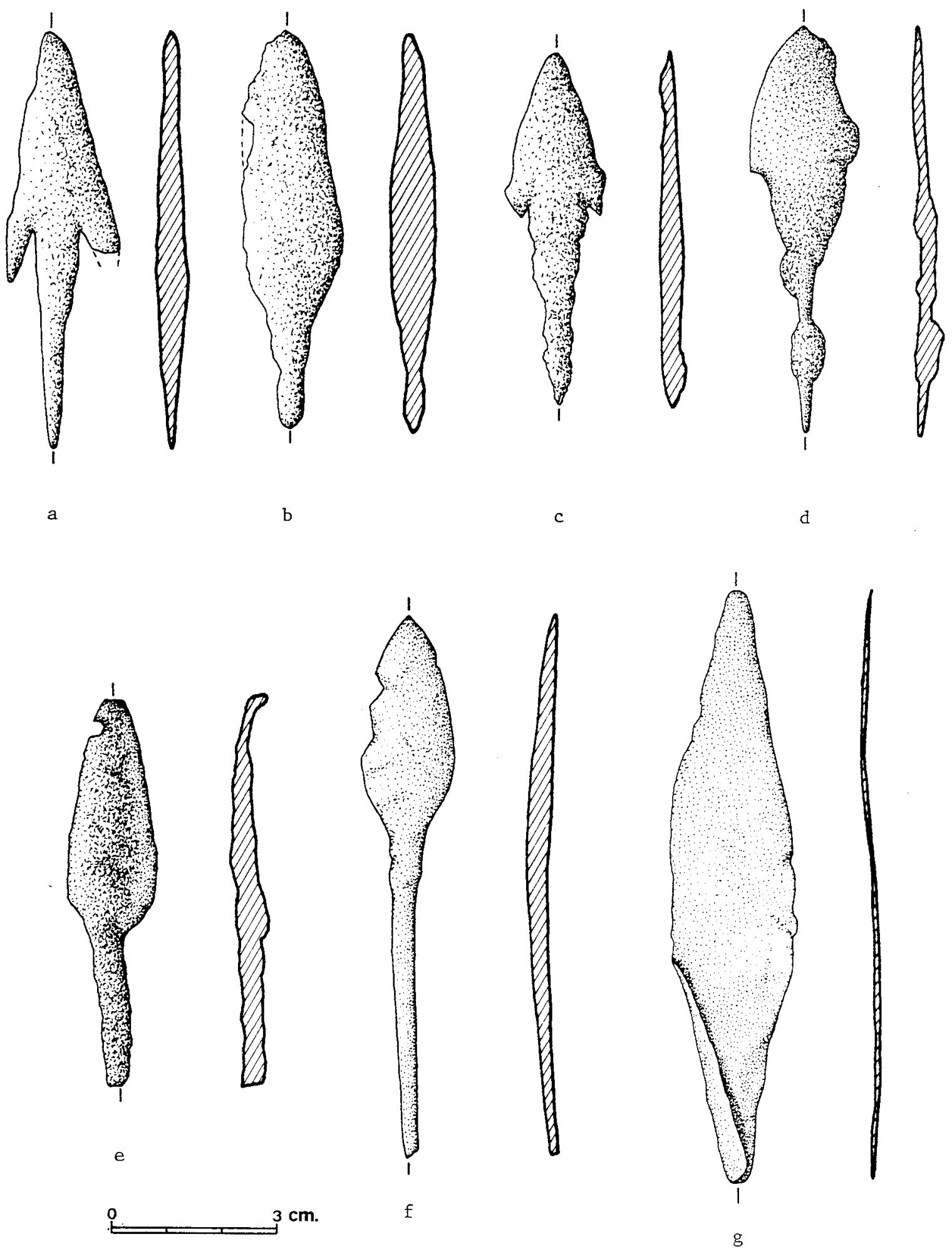

19. Puntal de Bartolo (Novelda) 


\section{Economía}

Se ha citado el hallazgo de trigo en el interior de dos capazos, pero aún no han sido analizados estos granos. En cuanto a otros restos vegetales o de fauna, no hemos podido constatar su existencia en ninguna de las dos colecciones. $\mathrm{Pa}$ rece probable la presencia de una actividad metalúrgica local, en base al hallazgo del pequeño lingote, aunque esto debe comprobarse convenientemente.

\section{Cronología}

La vivienda excavada por $\mathrm{M}$. Romero pertenece al último momento de la existencia del poblado, pues, tras su destrucción por un incendio, todo el ajuar permaneció en su sitio, sin ser removido por supuestos asentamientos posteriores, de los que no hay constancia.

Los materiales que forman ese ajuar presentan rasgos que inducen a situarlos en una fase avanzada en Plena Edad del Bronce. Muestra de ello son los cuencos muy abiertos, que en la Cultura del Argar son característicos de su fase $\mathrm{B}$; los vasos con cuellos exvasados y fondos paraboloides, que denotan un momento avanzado; y, en general, las pastas cuidadas y las superficies corrientemente pulimentadas, son indicios de un cierto grado de evolución.

Sin embargo, no se descarta el que hubiese un nivel anterior, al cual pudieran pertenecer algunas cerámicas más toscas.

En cuanto a su encuadre cultural, la mayoría de los tipos cerámicos son corrientes en el Bronce Valenciano y en esta área cultural parece estar inscrito el Puntal de Bartolo. Sin embargo, hay indicios que hacen pensar en ciertos contactos con el mundo argárico, las cuales quizás se produjeron en su fase B. Así se explicarían quizás los fondos paraboloides, las vasijas globulares con cuellos hiperboloides, comunes en aquella fase y presentes en la citada vivienda.

De ser cierta esta hipótesis esos contactos se producirían en un momento en que el Bronce Valenciano ya estaba consolidado en la zona y las corrientes foráneas incidirían débilmente en él.

\section{EL SAMB̈O}

El Sambo o Zambo es un cerro alargado N-S, situado sobre la margen derecha del río Vinalopó, en el límite de los términos municipales de Novelda y Mónovar (Alicante). Coordenadas geográficas: $38 .^{\circ} 25^{\prime} 21^{\prime \prime}$ lat. N. y $0^{\circ} 48^{\prime} 39^{\prime}$ ' long. W. del meridiano de Greenwich.

En la cima (400 m. s.n.m.) y laderas se han realizado hallazgos arqueológicos desde hace muchos años. Entre ellos la aparición de enterramientos con armas de bronce y hierro, así como vasijas de cerámica. Estas noticias motivaron el que algunos aficionados efectuasen rebuscas que han sembardo de hoyos sus laderas y cumbre.

En 1975 y 1976 fue prospectado por el grupo 688 de Operación Rescate, que recogieron algunos materiales. Nosotros visitamos el yacimiento en 1978 . 
El Sambo ha sido ocupado por diferentes culturas y civilizaciones. Es probable que primeramente fuese un asentamiento del Bronce, reocupado al menos en época ibérica, romana y medieval. A estas últimas épocas corresponden cerámicas a torno, sigillata, fragmentos de tegulae y reciente el hallazgo de una lucerna paleocristiana así como una moneda aún sin clasificar.

Los materiales de la Edad del Bronce, en la citada Colección Rescate son: parte de un cuenco de tendencia paraboloide con borde entrante, pasta cuidada, color negro y superficie bruñida (fig. 20, b). Parte de un cuenco semiesférico sencillo, pasta cuidada, color negruzco y superficie alisada (fig. 20, a). Fragmento de borde de un gran pithos ovoide con mamelones en el borde, pasta regular, aunque con mucho desgrasante, color negruzco y superficie espatulada. Fragmento de panza de una gran vasija con un cordón con impresiones, pasta poco cuidada con desgrasantes groseros, color marrón claro y superficie espatulada. Fragmento de vasija con un asa de cinta. Borde de vasija de unos $12 \mathrm{cms}$.
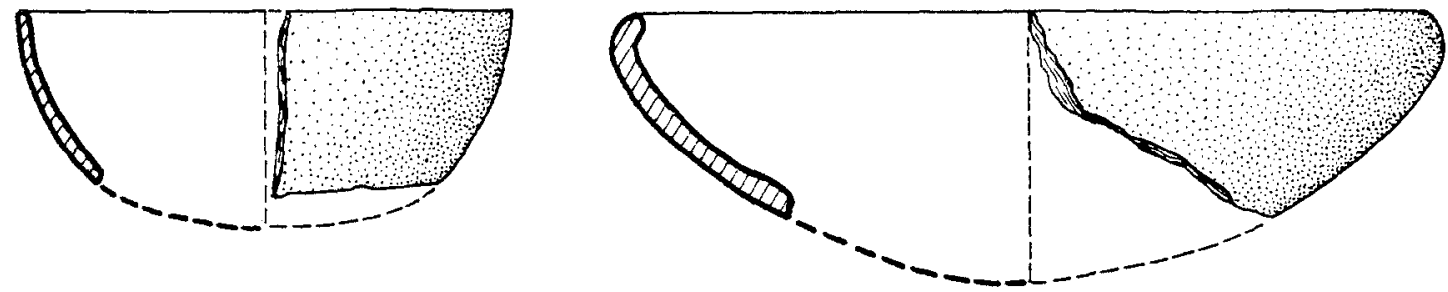

a

b
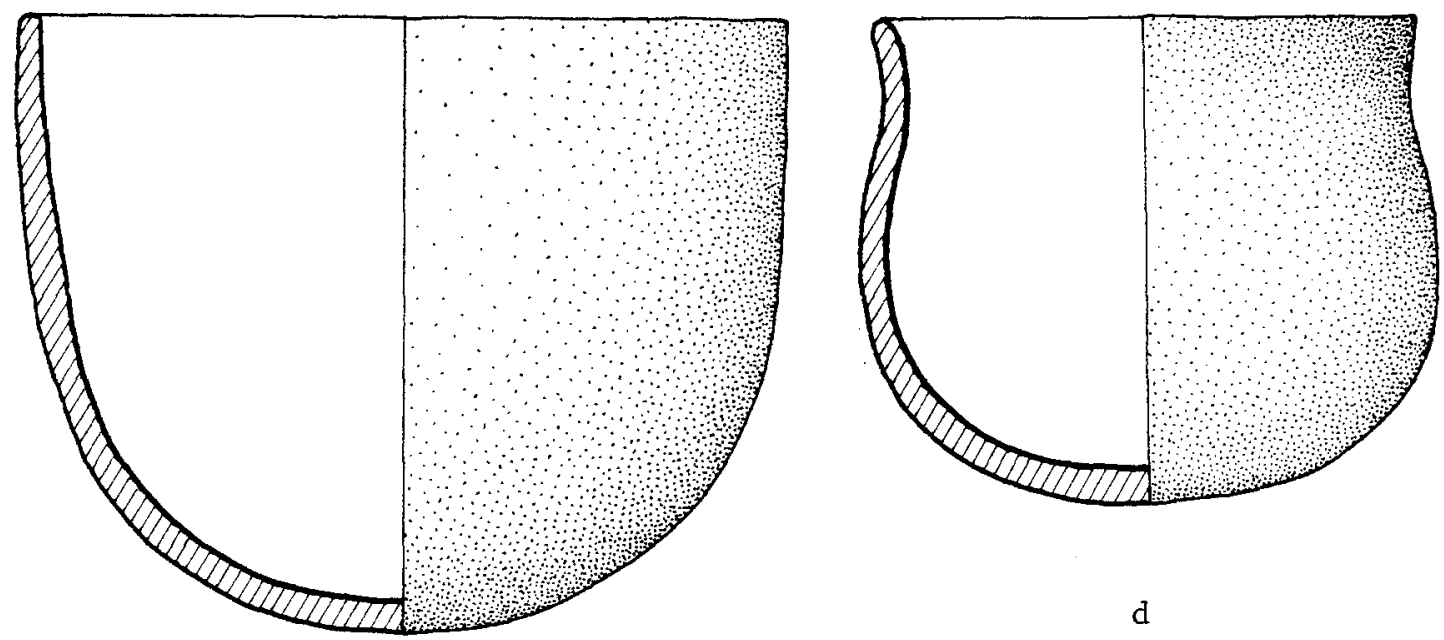

d

C

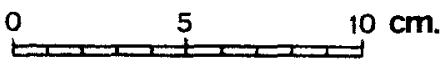

20. El Sambo (Monóvar-Novelda) 
de diámetro - quizás semielipsoide-, borde recto con mamelón, pasta poco cuidada con desgrasantes groseros, color negruzco. Borde de vaso similar, de 15 cms. de diámetro, borde exvasado, pasta cuidada, color negruzco y superficie alisada. Otro fragmento similar. Fragmento de borde de pequeño cuenco semiesférico de paredes rectas, pasta regular, color marrón oscuro y superficie espatulada. Otro similar, de color marrón claro. Fragmento de hombro y cuello de gran vasija ovoide con cuello exvasado, pasta cuidada, color desde rojizo a negruzco y superficie bruñida-alisada. Otro similar, pero con largos y estrechos mamelones. Otros fragmentos de vasijas de pasta cuidada unas y poco cuidadas otras, entre ellos varias de probables cuencos paraboloides de borde entrante y una probable gran vasija carenada.

De sílex blanco hay una lasca con retoques marginales.

En la colección de M. Romero Iñesta se guardan: un vaso semielipsoide sencillo, de pasta grosera, color marrón claro, mal cocida y superficie toscamente espatulada ( $22 \mathrm{cms}$. diámetro, $17,7 \mathrm{cms}$. alto) (fig $20, \mathrm{c}$ ). Vaso de tendencia esférica con borde exvasado, pasta poco cuidada, marrón claro, mal espatulada ( $15,7 \mathrm{cms}$. diámetro boca, $14 \mathrm{cms}$. altura) (fig. 20, d). Seis fragmentos de pequeños cuencos de bordes entrantes, paredes finas, pasta cuidada y superficie bruñida. Cuatro fragmentos con mamelones. Seis fragmentos de cerámica algo cuidada, espatulada, de vasos esféricos o elipsoides. Un elevado número de vasijas y fragmentos de cerámicas árabes, ibéricas, algunas romanas, campanienses, etc.

De sílex hay noventa y siete dientes de hoz; además de once que fueron hallados en el interior del vaso esférico, junto con restos del enmangue, todo ello muy afectado por el fuego.

Varias lascas sin retoques, en sílex blanco y gris. Algunos pequeños cantos rodados; tres molinos naviformes, uno con su piedra móvil. Un objeto - quizás mano de mortero - troncocónico de base cóncava en granito verde.

Además, una concha de Glycimeris sp. perforada y medio brazalete de pectúnculo.

En general, los materiales son similares a los del Pont de la Jaud.

\section{EL SAMBO MENOR}

Entre el Sambo y el río Vinalopó hay dos pequeños cerros, el menor de los cuales ( 330 m. s.n.m.) ha sido denominado «Sambo Menor» (V. GOMEZ GARCIA: 1976, p. 11). Término municipal de Novelda (Alicante). Coordenadas geográficas: $38^{\circ} 25^{\prime} 19^{\prime}$ ' lat. N. y $0^{\circ} 48^{\prime} 20^{\prime}$ ' long. W. del meridiano de Greenwich.

El yacimiento fue descubierto en su cima por el grupo de Operación Rescate n. ${ }^{\circ}$ 688. En 1978 fue dado a conocer por dicho grupo (GRUPO DE RESCATE 688: 1978, p. 61). En 1979 fue visitado por nosotros.

La cima del cerro está ocupada por una cresta rocosa que va de Este a Oeste, interrumpiéndose en un sector donde se observa una alineación de piedras, junto al cual el citado grupo de Rescate realizó una cata sin resultado positivo.

En superficie, por las laderas, hay fragmentos de cerámica de color rojizo, tosca y algunos trozos de sílex.

Más que de un poblado, debe tratarse de una sola vivienda, quizá una prolongación del Sambo. 


\section{PONT DE LA JAUD}

Es un cerro alargado de NE. a SW., situado en la margen izquierda del río Vinalopó, que lo bordea por dos de sus lados. Un trozo de él queda en el término municipal de Monóvar y la mayor parte en la de Elda (Alicante). Coordenadas geográficas: $38^{\circ} 26^{\prime} 13^{\prime \prime}$ lat. N. y $0^{\circ} 48^{\prime} 32^{\prime \prime}$ long. W. del meridiano de Greenwich.

La ladera NW. es muy pendiente, rematada por un escarpe de unos pocos metros de altura, lo cual impide el acceso por esta parte. Por el contrario, la vertiente opuesta es de pendiente más suave y de fácil subida. En la cima del cerro existen tres crestas escalonadas, separadas por especie de collados, en los que se situaba el poblado, así como en la ladera SE.

Actualmente el cerro ha sido cortado transversalmente en dos por el trazado del ferrocarril Alicante-Madrid.

El yacimiento fue descubierto en 1976 por los grupos 688 y 689 de Operación Rescate, del Colegio «Padre Dehón» de Novelda. Su profesor jefe, V. Gómez García, nos comunicó su existencia en 1977, no teniendo ocasión de visitarlo hasta el año siguiente, en su compañía y la de M. S. Hernández Pérez. En el curso de esos dos años, el yacimiento había sido en gran parte destruido por excavadores furtivos (GRUPO DE RESCATE 688: 1978, p. 61).

Existían algunos restos de lo que pudo haber sido una muralla de piedra y barro, en la ladera sudoriental, destruida por los agricultores con el fin de aprovechar las piedras para unos bancales cercanos. En la misma ladera existen algunos vestigios de muros pertenecientes a viviendas escalonadas arrasados por los clandestinos. De ellas debe proceder la gran cantidad de piedras de mediano tamaño que cubre la ladera y las pellas de barro blanquecino endurecido con improntas de cañas, ramas y esparto, que abundan también.

En la cima y laderas abundan la cerámica y los molinos naviformes.

En la Colección Rescate del citado colegio, se guardan los siguientes materiales: un cuenco de tendencia semiesférica y borde recto, de pasta relativamente cuidada, color marrón-rojizo e intenso espatulado, aunque sin bruñido $(10,6$ cms. diámetro, $7 \mathrm{cms}$. altura) (fig. $21, \mathrm{~b}$ ). Cuenco de casquete esférico, fondo de tendencia paraboloide, pasta cuidada, color gris oscuro y superficie bruñida (16 cms. diámetro, 6,5 cms. altura) (fig. 21, a). Cuenco paraboloide con bordes entrantes de labio biselado, pasta cuidada, color beige y superficie bruñida $(9,2$ cms. diámetro, $6,4 \mathrm{cms}$. altura) (fig. $21, \mathrm{c}$ ). Cuenco paraboloide con bordes entrantes de labio biselado, pasta cuidada, color gris y superficie bruñida $(11,7$ cms. diámetro máximo, 9,6 cms. diám. boca y 4,4 cms. altura) (fig. 21, d).

La industria lítica incluye cinco dientes de hoz; dos lascas de sílex blanco, sin retoques; una lámina de sílex blanco, sin retoques; un fragmento de gran lámina de sílex melado, con retoques de uso; un canto rodado desbastado, con arista muy desgastada; una afiladera prismática; dos molinos naviformes, parte de otro y una pieza móvil; una azuela de piedra blanquecina.

Como adorno han de considerarse dos conchas de Glycymeris sp. con el natis perforado; dos cuentas de collar de una piedra verde brillante, una es en forma de tonel con orificio bitroncocónico $(2,4 \times 1,6 \mathrm{cms}$.) y la otra troncocónica con orificio troncocónico $(1,3 \times 1,1 \mathrm{cms}$.) 
Durante la prospección de 1978 fue hallado un fragmento de punzón de bronce, de sección circular.

M. Romero Iñesta nos comunicó en agosto de 1978 el hallazgo de un vasito de color negruzco y varios dientes de hoz.

En el citado colegio se guardan algunos huesos fragmentados de ovicápridos, grandes herbívoros (¿caballo o buey?) y piezas dentales de Canis sp., entre otros no identificados.

Estos pocos materiales no permiten extraer conclusiones culturales o cronológicas, salvo que su inclusión en el Bronce Pleno es clara. Sin embargo, hemos de atraer la atención al hecho de que no son corrientes en el Bronce Valenciano los cuencos con borde muy entrante, finas paredes y superficie bruñida, que presenta el Pont de la Jaud. Quizás no debería descartarse la posibilidad de influencias de otra área cultural.

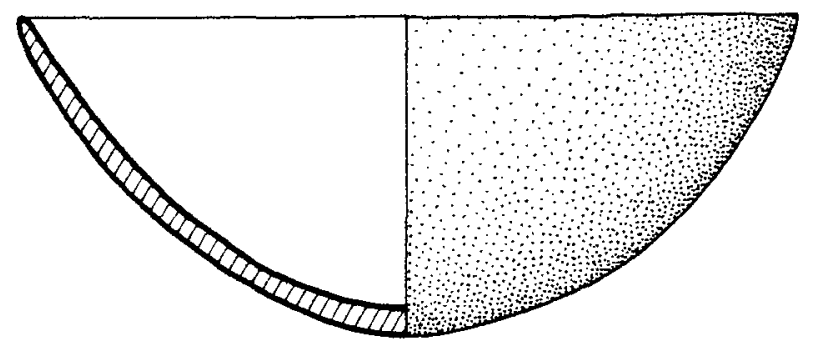

a

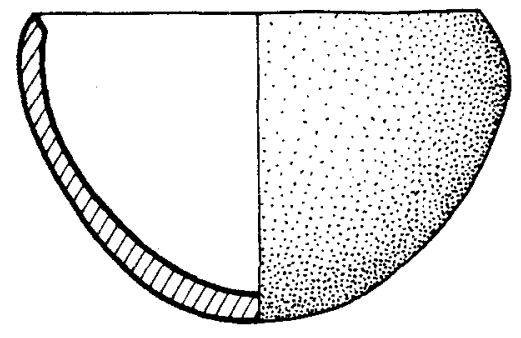

c

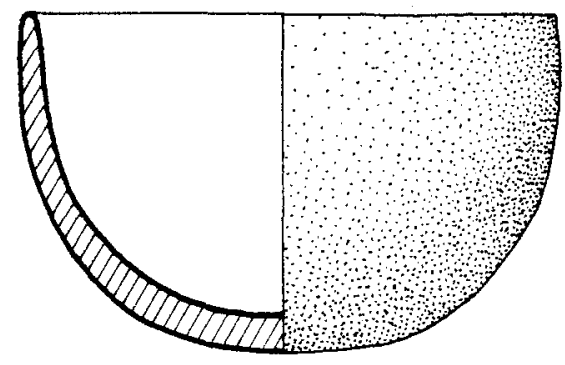

b

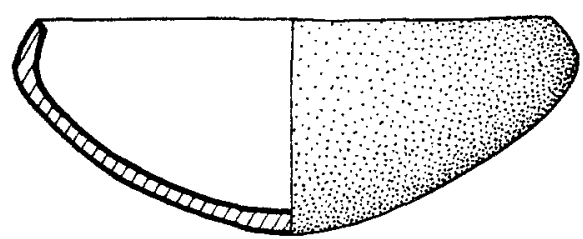

d 


\section{EL TABAYA}

\section{Situación e historia de la investigación}

El río Vinalopó, tras atravesar el valle medio, cruza las Sierras de Aspe (Alicante), encajándose en una especie de cañón flanqueado en su margen izquierda por el monte Tabayá o Tabaiá. Este adopta una posición alargada de Este a Oeste y presenta tres crestas, lamiendo el río su vertiente occidental. Coordenadas geográficas: $38^{\circ} 19^{\prime} 59^{\prime}$ ' lat. N. y $0^{\circ} 43^{\prime} 20^{\prime}$ ' long. W. del meridiano de Greenwich.

Los aficionados de Elche y Novelda conocen este yacimiento desde hace tiempo, si bien nunca se han realizado en él investigaciones, a pesar de haber sido citado por R. Navarro Castelló (R. NAVARRO CASTELLO: 1978, p. 26) y ser objeto de continuas rebuscas por parte de los citados aficionados, lo cuales han dejado en su cima y laderas huellas evidentes.

El poblado debió situarse en los rellanos que hay entre las tres crestas citadas, desde donde se domina tanto el valle medio del Vinalopó como la comarca de Elche. Pero existen señales de que también se extendió por las laderas.

En la vertiente SE., en un rellano, existen dos construcciones tumulares, una de ellas violada, en donde fueron hallados materiales del Bronce Final o de los inicios del Hierro semejantes a otros que se encuentran en superficie por la ladera del cerro. (Información oral de don Vicente Gómez. No hemos visto estos materiales).

\section{Materiales muebles}

La Colección Rescate del Colegio Padre Dehón, de Novelda contiene de este yacimiento: una gran vasija de fondo paraboloide y cuello exvasado, pasta regular superficie marrón oscuro - marrón rojizo - negruzco y espatulada $(42 \mathrm{cms}$. diám. máx. y $26 \mathrm{cms}$. alt.) (fig. 22, e). Cuenco paraboloide de borde entrante, pasta regular, superficie de color marrón claro y espatulada, aunque irregular $(8,2 \mathrm{cms}$. diám. y $5,8 \mathrm{cms}$. alt.) (fig. 22 , a). Vaso con cierta tendencia esférica, pero de perfil asimétrico con cuatro mamelones próximos al borde, pasta poco cuidada, superficie beige amarillenta y espatulada ( $20 \mathrm{cms}$. diám. máx. y 15,6 cms. alt.) (fig. 22, b). La industria lítica incluye un canto rodado de cuarcita al que se han extraído dos lascas; dos lascas sin retoques en sílex gris y crema veteado; dos dientes de hoz en sílex melado y crema. De hueso hay un fragmento de punzón.

Más rica es la colección de M. Romero Iñesta, que incluye: 1) Un cuenco semielipsoide asimétrico, de pasta grosera, superficie color marrón oscuro e irregular $(24,5 \mathrm{cms}$. diám. máx. y 18,5 cms. alt.) (fig. 22, d). 2) Cuenco semielipsoide de fondo plano y borde entrante, pasta poco cuidada, superficie gris oscura y espatulada aunque irregular ( $20 \mathrm{cms}$. diám. máx. y 14,5 cms. alt.) (fig. 24, d). 3) Cuenco semiesférico de borde entrante, pasta regular, superficie marrón claro y espatulada (18 cms. diám. máx. y $11 \mathrm{cms}$. alt.) (fig. 24, b). 4) Cuenco de tendencia esférica, pasta cuidada, superficie rojiza-grisácea y negruzca por zonas y 
bruñida (14,8 cms diám. máx. y 10,6 cms. alt.) (fig. 24, e). 5) Cuenco semiesférico de pasta cuidada, color marrón oscuro, bruñida $(19,2 \mathrm{cms}$. diám. y $8 \mathrm{cms}$, alt.) (fig. 24, c). 6) Vaso troncocónico invertido, de pasta poco cuidada, color beige claro mal alisada e irregular; en la base tiene la impronta de una esterilla de esparto (19 cms. diám. y 9,6 cms. alt.) (fig. 22, c). 7) Pequeño vaso con carena baja y borde ligeramente exvasado, pasta cuidada, superficie marrón claro a gris y bruñida $(7,8 \mathrm{cms}$. diám. máx. y $6 \mathrm{cms}$. alt.) (fig. 23, c). 8) Cuenco semielipsoide con dos mamelones asimétricos junto al borde, pasta poco cuidada, superficie marrón grisácea y mal espatulada $(11,3 \mathrm{cms}$. diám. máx. y $10 \mathrm{cms}$. alt.) (fig. 23, d). 9) Vaso paraboloide con cuello exvasado, pasta poco cuidada, marón claro a gris o' espatulada $(19,2 \mathrm{cms}$. diám. máx. y $13 \mathrm{cms}$. alt.) (fig. 24, a). 10) Cuenco de tendencia semiesférica con cuatro mamelones asimétricamente repartidos, pasta grosera, superficie gris con zonas rojizas y ligero bruñido $(29,7$ cms. diám. máx. y $20 \mathrm{cms}$. alt.) (fig. 23, b). 11) Vaso con tendencia a carena con el cuerpo inferior semiesférico y el superior troncocónico de borde exvasado con un mamelón en la línea de carenación, color marrón claro a negruzco y espatulada-alisada ( $31 \mathrm{cms}$. diám. máx. y $33 \mathrm{cms}$. alt.) (fig. 25, a); en su interior y hasta media altura contenía habas carbonizadas. 12) Vasija de cierta tendencia esférica con cuello exvasado, pasta regular, superficie de color negruzco con zonas ocres y espatulada (39,8 cms. diám. máx. y 30,1 cms. alt.) (fig. 23, a). 13) Pequeño cuenco semiesférico con un ligero cuello cilíndrico, pasta cuidada, de color marrón y pulimentada (12,2 cms. diám. máx. y $7 \mathrm{cms}$. alt.) (fig. 25, b). 14) Fragmento de un vasito carenado, con engrosamiento en la carena, de pasta cuidada, superficie rojiza y bruñida (fig. 25 , c). De un Bronce Final o Tardío son: 15) Un cuenco troncocónico invertido con fondo convexo y carena, pasta cuidada, superficie negruzca y bruñida (lám. II, a); en su interior contiene trigo carbonizado. 16) Un cuenco semiesférico con rebaje en el tercio superior, pasta cuidada, superficie beige y pulimentada (lám. II, b). 17) Vasija esférica con cuello exvasado, ónfalo en la base y asa de cinta, pasta regular, superficie marrón oscura y alisada; decoración de boquique con relleno de pasta clara y anchas incisiones, formando triángulos rellenos de líneas paralelas, tres paralelas de zigzag en el cuello y puntilleado en torno al asa $(10 \mathrm{cms}$. diám. boca y $12,4 \mathrm{cms}$. alt.) (lám. I, d). 18) Vasija carenada con cuello cilíndrico, labio curvo, fondo plano y dos mamelones gemelos en la carena perforados vertivalmente, pasta cuidada, superficie marrón negruzca y bruñida; decoración en los hombros de incisiones formando reticulado con relleno de pasta blanca $(17,5 \mathrm{cms}$. diám. máx. y $9 \mathrm{cms}$. alt.) (lám. I, a). 19) Vasija paraboloide de borde entrante, labio biselado y fondo plano con cuatro mamelones reconstruidos en los hombros simétricamente distribuidos, pasta cuidada, superficie de marrón a negruzca y pulimentada; decoración en los hombros y rodeando los mamelones a base de acanaladuras paralelas $\mathrm{y}$, bajo ellas, triángulos rellenos de líneas paralelas, todo con relleno de pasta blanca ( $31 \mathrm{~cm}$. diám. boca y $19,1 \mathrm{cms}$. alt.) (lám. I, b). 20) Vasija paraboloide con cuello exvasado, labio recto, fondo plano y dos asas de cinta reconstruidas, pasta cuidada, superficie marrón grisácea y bruñida; decoración en los hombros a base de suaves acanaladuras rellenas de pasta blanca, formando tres líneas horizontales de las que parten hacia abajo líneas oblicuas paralelas $(34,3$ cms. diám. boca y 12,5 cms. alt.) (lám. I, c). Hay, además, muchos fragmentos 


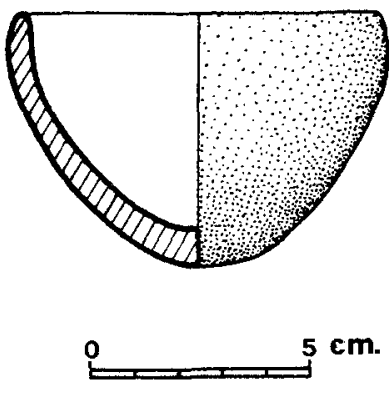

a
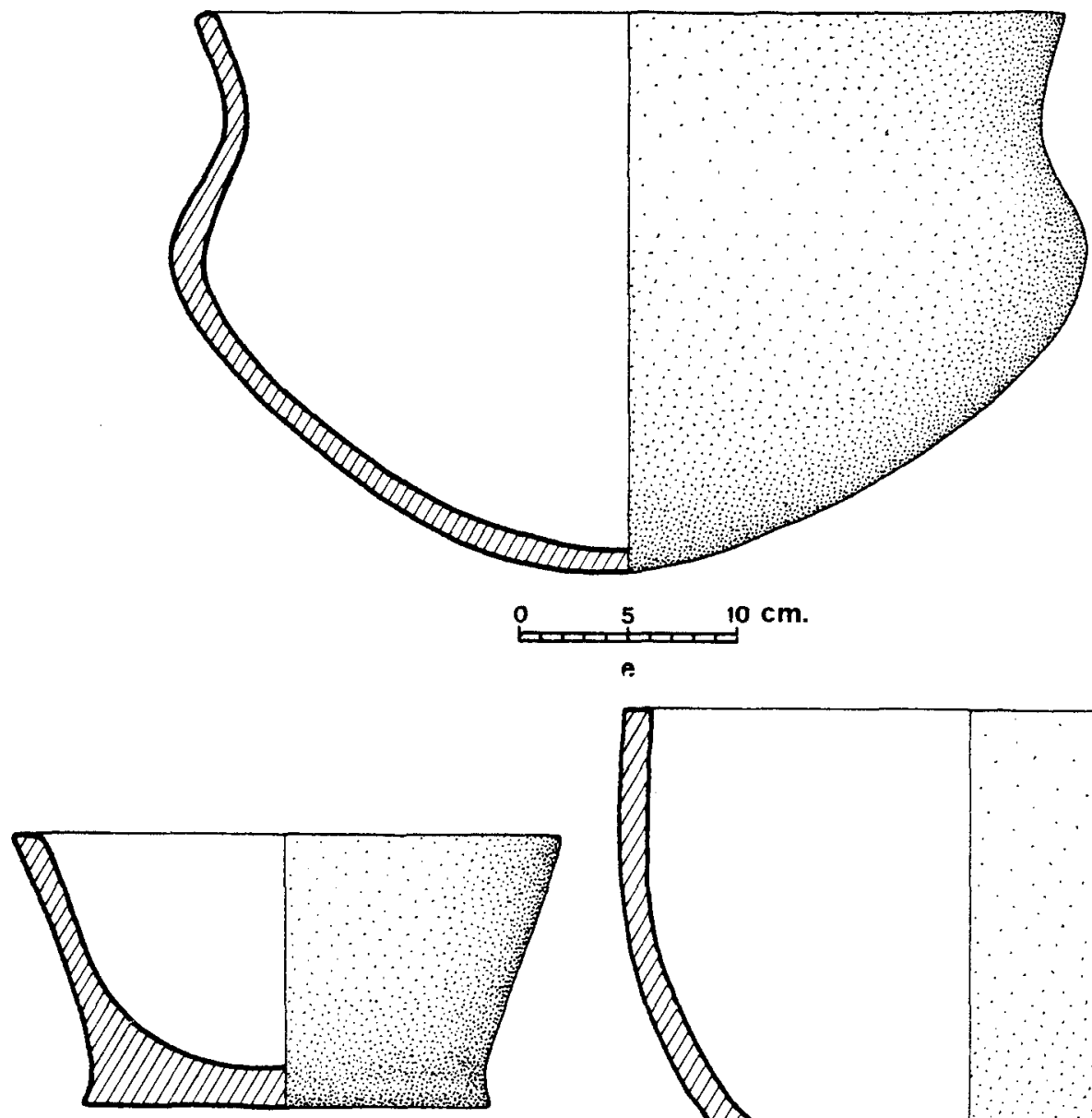

c

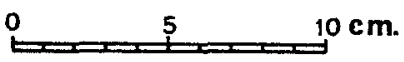

22. El Tabayä (Aspe) 

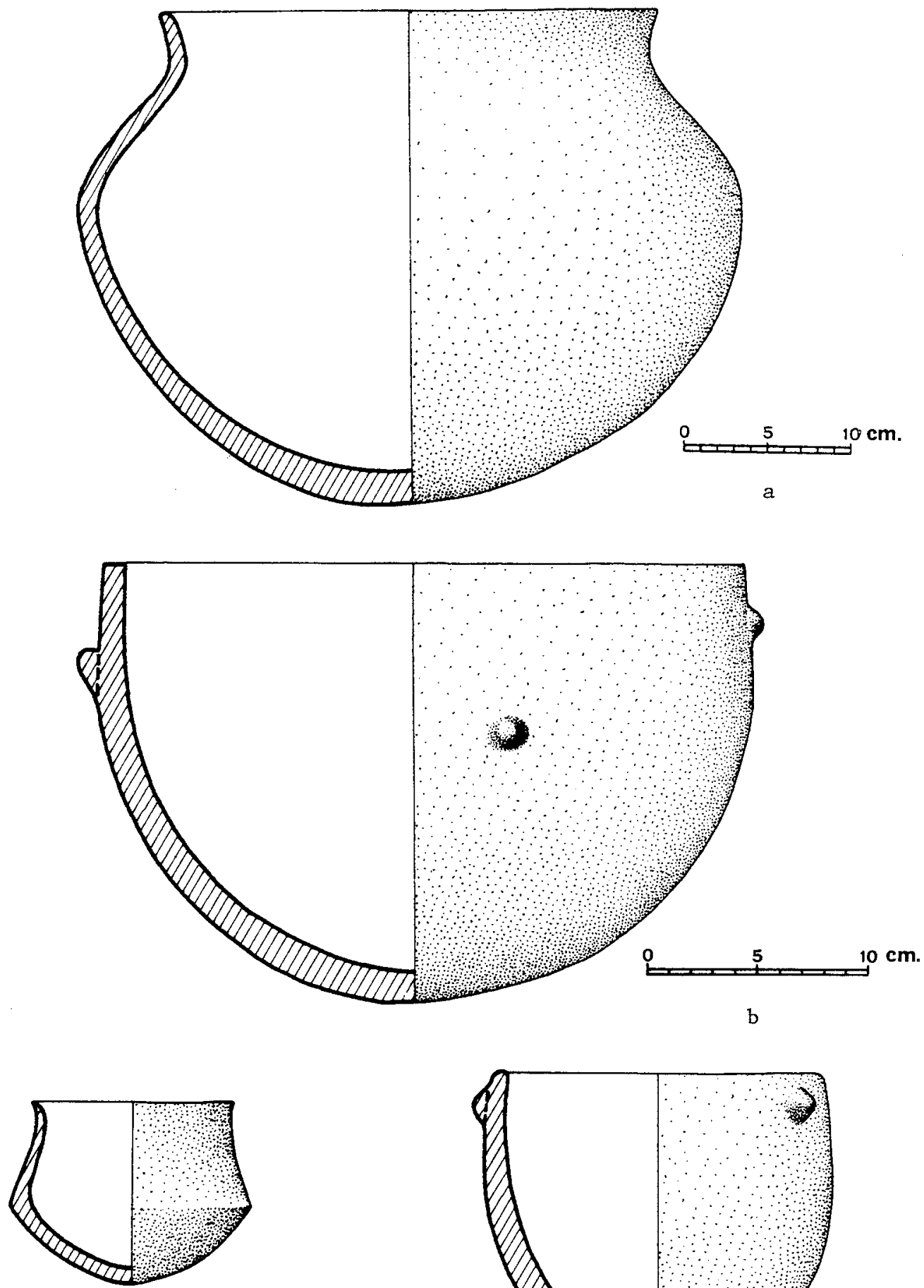

c

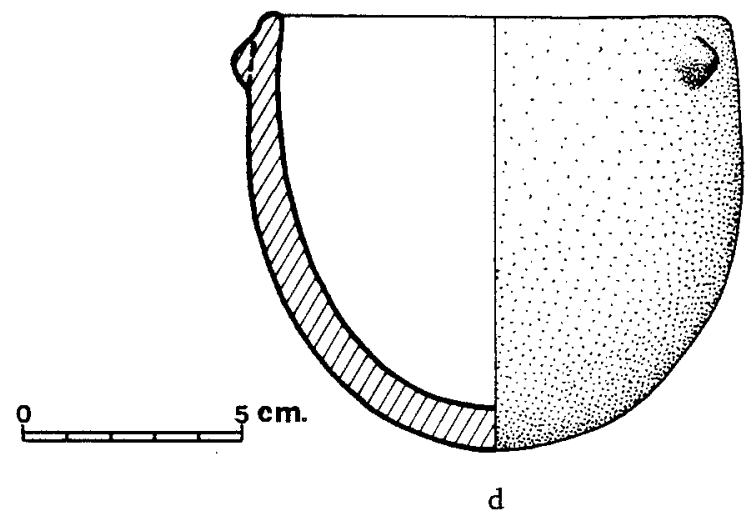

23. El Tabayá (Aspe) 

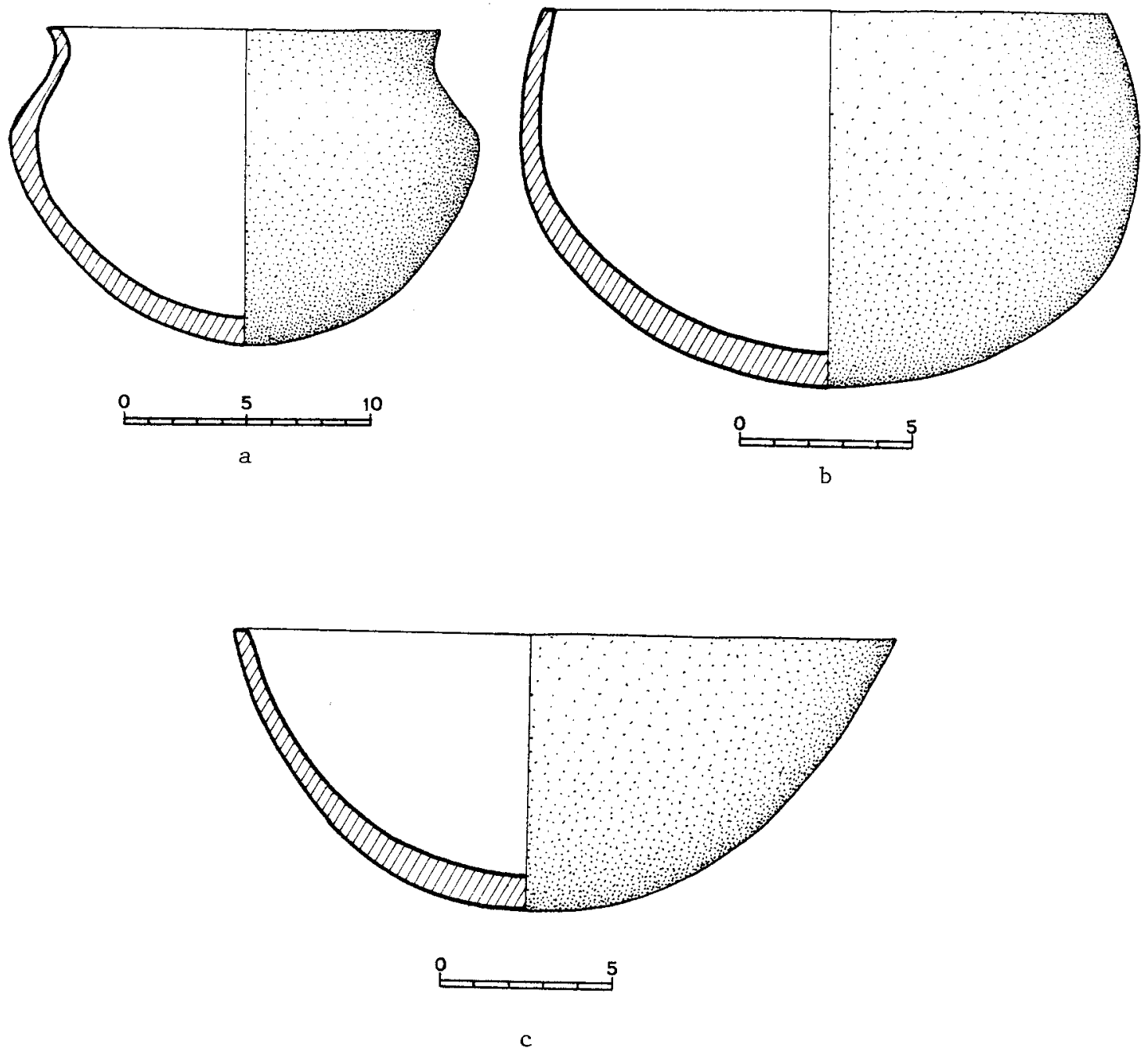
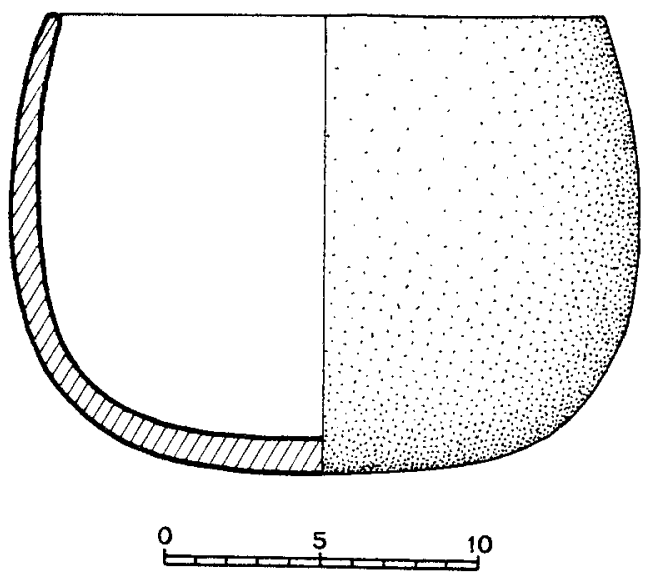
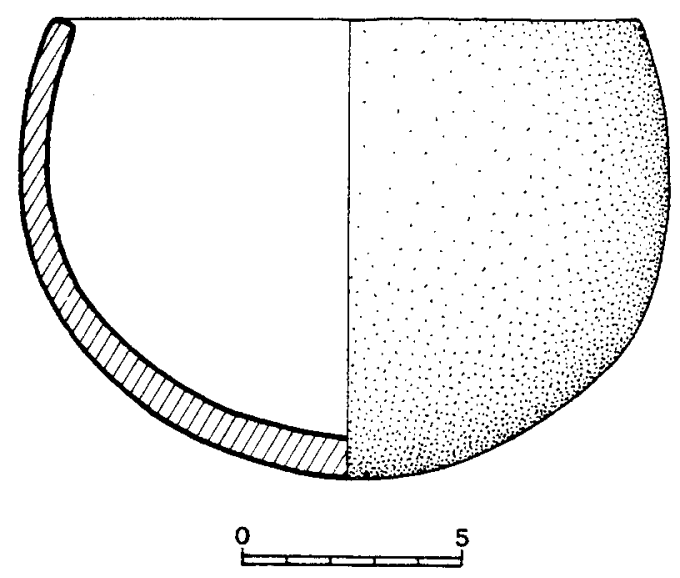

24. El Tabayá (Aspe) 


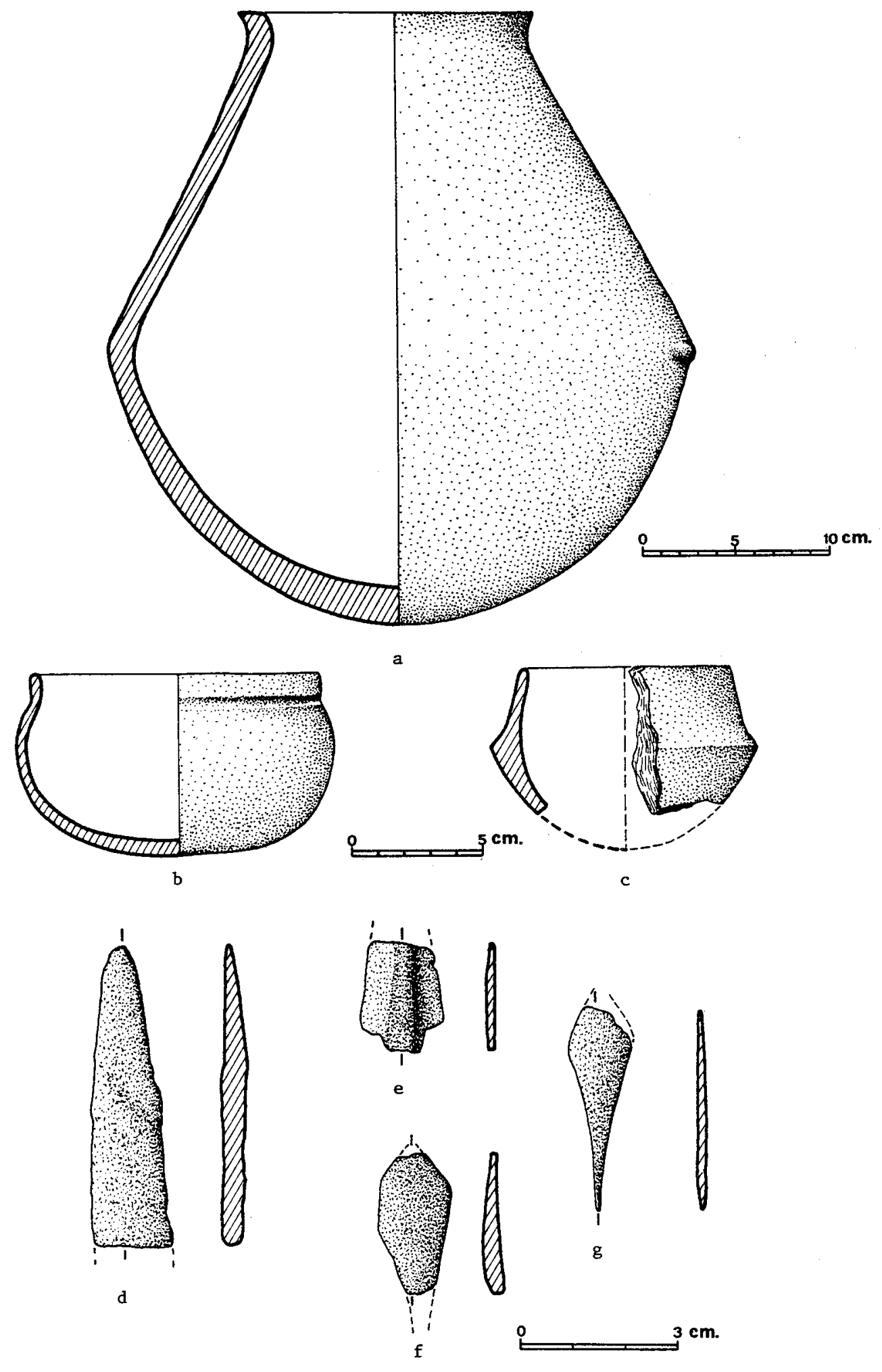

25. El Tabayá (Aspe) 
más de cerámica, entre ellos veinte con mamelón; once con asa de cinta; seis con asa de lengüeta, alguna con impresiones; un borde decorado con ungulaciones; tres fragmentos muy bruñidos pertenecientes a pequeños cuencos, dos de ellos con orificio cerca del borde; un fragmento de una gran vasija con dos mamelones grandes gemelos, cada uno con una impresión digital que los ha aplanado; diez fragmentos de cerámica con acanaladuras, incisiones, impresiones y boquique (lám. I, e-f); un fragmento de borde exvasado y panza, de pasta cuidada, color marrón grisáceo y decoración acanalada formando motivos geométricos; tres fragmentos de vasijas escurrideras. Finalmente, existen algunos fragmentos de cerámica lisa, negruzca, pertenecientes a vasos troncocónicos y bitroncocónicos, característicos de los Campos de Urnas, y que aparentemente aparecieron en la parte baja de la ladera Norte del cerro. También medio cuenco campaniforme con decoración muy barroca y aspecto bastante tardío, el cual fue donado a dicho coleccionista, siendo atribuido a este yacimiento, si bien las circunstancias del hallazgo y la autenticidad misma de esta atribución nos of recen serias dudas.

La industria lítica: tres azuelas de granito y basalto y cinco fragmentos de otras; dos piedras molederas semiesféricas; varios pequeños cantos rodados; dos molinos naviformes, uno de caliza porosa y el otro en basalto cavernoso; un molino naviforme en caliza porosa con mango romboidal en un extremo. De sílex hay treinta y ocho dientes de hoz; un núcleo empleado como percutor; veinte lascas y láminas, algunas con pequeños retoques de uso. Medio brazalete de arquero.

La industria ósea: nueve punzones.

La industria metálica: medio puñal de cobre o bronce (fig. 25 , d); dos puntas de flecha tipo Palmela fragmentadas y parte de otra con nervadura en una cara (fig. 25, e-g); un punzón de sección cilíndrica; varios fragmentos de punzones; algunas escorias de metal (cobre o bronce).

Adornos a base de moluscos marinos perforados: hay veintiuna valvas de Glycimeris glycimeris, cinco de Cardium edule, cuatro caracoles de Thais haemastoma y varios de Littorina neritoides, Conus mediterraneus y Cypraea sp. Además, hay dos colgantes labrados en concha, dos cuentas de material vítreo rojo y verde; un collar de pequeñas cuentas de piedra.

En la colección de A. Alberola, también de Novelda, existen procedentes de este yacimiento: una alarbada de cobre o bronce casi completa, así como dos hachas pequeñas del mismo metal. También un anillo y varios botones de apariencia tardía.

\section{Economía}

Además de las conchas agujereadas ya citadas, la colección M. Romero incluye una valva y dos fragmentos más de Cardium edule y una concha de Patella aspera. También un colmillo y huesos de cerdo (Sus domesticus) y quizá de corzo (Capreolus capreolus), entre otros.

Ya se citó el hallazgo de trigo (Triticum sp.) y habas (Vicia faba), ambos en vasijas que deben incluirse en un Bronce Final para el caso del trigo y Bronce Final o Tardío en el de las habas.

La presencia de escorias indica que hubo producción metalúrgica local. 


\section{Cronología}

En El Tabayá hay materiales encuadrables dentro de un Bronce Valenciano pleno, otros de un Bronce Tardío y Final, cuyo origen debemos buscarlo en la Meseta y otros propios de los Campos de Urnas. Los primeros y los segundos son los más abundantes y aparecieron en la parte alta del cerro, especialmente en la vertiente que da sobre el Pantano de Elche. Esas cerámicas decoradas, tan abundantes en este yacimiento, presentan una clara ascendencia en el Horizonte Cogotas I, cuyas gentes debieron llegar hasta El Tabayá y no sólo sus influencias. Los materiales de los Campos de Urnas - algunas cerámicas - aparecieron en la parte baja de la ladera Norte, la que mira al Valle Medio del Vinalopó y cae sobre dicho río, si bien las circunstancias de su hallazgo nos parecen algo confusas.

Esta diversidad de materiales y horizontes culturales en un solo yacimiento hace que El Tabayá sea hoy por hoy el más interesante poblado de los que conocemos en el Valle Medio y Bajo del Vinalopó, y en donde pudieran estar muchas claves sobre el poblamiento de la zona en el $\mathrm{II}^{\circ}$ milenio y parte del $\mathrm{I}^{\circ}$. Lástima que su estado de conservación sea tan deficiente.

\section{CONCLUSION}

La mayor parte de los materiales aquí presentados tienen cabida en las tablas tipológicas generales del Bronce Valenciano, pero existe una mayor similitud aún entre los propios yacimientos del Valle Medio del Vinalopó, lo que le da cierta personalidad a la comarca y afianza la idea de una fuerte nuclearización cultural en el Bronce Pleno de la Península Ibérica, con variantes regionales o comarcales dentro de las propias culturas, que parecen estar muy claras en el caso concreto del Bronce Valenciano.

Evidentemente, todos estos materiales y poblados no son contemporáneos y una gran parte tiene un aspecto tardío, pero las circunstancias de su hallazgo impiden realizar con ellos una clara secuencia cronológica. Sin embargo, la mayoría pueden ser incluidos en el Bronce Pleno y dentro de la cultura del Bronce Valenciano, a pesar de que, a nuestro juicio, existan también algunos elementos del tránsito Eneolítico-Bronce en Casa Paus y materiales de un Bronce Tardío en varios yacimientos, así como otros muy claros del Bronce Final en El Tabayá o Tabaiá.

Los hallazgos de Casa Paus, aunque escasos (puntas de flechas en sílex, brazalete de arquero, metal, cerámica carenada, diente de hoz) y las características mismas del poblado (en una pequeña elevación sin defensas naturales y con viviendas cuadrangulares) creemos que permiten situarlo en un momento de tránsito entre el Eneolítico y el Bronce Valenciano pleno.

Entre los materiales de los restantes poblados, la mayoría pueden ser considerados del Bronce Valenciano, aunque no todos parecen contemporáneos; las cerámicas de La Esparraguera (fig. 2) parecen corresponder a un B. V. avanzado o tardío. Los bordes muy exvasados de algún cuenco de La Lloma Redona (fig. 4, a) y la vasija con dos asas y cuello (fig. 3, a) apuntan a un B. V. avanzado en el primer caso y a un B. V. avanzado o tardío en el segundo, con paralelos en 
San Antón (Orihuela) (J. FURGUS: 1977, IV, lám. I) y en el Cabezo Redondo (Villena). Los grandes vasos del Murón (fig. 6 y lám. II, c), los cuencos muy abiertos (fig. 8) y las puntas de flecha con aletas y pedúnculo pueden corresponder a un B. V. avanzado, mientras que la especie de copa bitroncocónica (fig. 7, c) puede ser del mismo momento o algo posterior. El fragmento de cerámica decorada del Portixol (fig. 10, f) debe ser de un B. V. tardío. En el Puntal de Bartolo, las vasijas con cuello (figs. $11, \mathrm{~b} ; 12, \mathrm{a} ; 13, \mathrm{~d} ; 16, \mathrm{a} ; 17$ ), los vasos paraboloides de cuello incipiente y cuatro u ocho mamelones (fig. 18), los cuencos muy abiertos (fig. 14, f), alguna forma carenada (fig. 16, b) y las puntas de flecha con pendúnculo y aleta pueden ser de un B. V. avanzado. En el mismo momento creemos que deben incluirse los cuencos de paredes finas y borde marcadamente entrante del Sambo (fig. 20, b) y Pont de la Jaud (fig. 21, c-d) o de paredes muy abiertas (fig. 21, a). En El Tabayá, los vasos con cuello exvasado (figs. 22, e; 23, a; 24 , a), el cuenco de fondo plano (fig. 22 , c), el vaso de la fig. 25 , a, y el puñal (fig. 25 , d) pueden ser de un B. V. avanzado o tardío; la punta de flecha nervada (fig. 25, e) de un B. V. tardío o Bronce Final, mientras que las restantes puntas presentan cierto primitivismo, al igual que muchas cerámicas; pero las cerámicas acanaladas, con boquique, incisas e incluso excisas, a menudo con relleno de pasta blanca (lám. I) son evidentemente de un Bronce Final con paralelos en el horizonte Cogotas I; mientras que los cuencos de la lám. II (a y b) pueden ser de un B. V. tardío o de un Bronce Final.

En general, sus paralelos se encuentran en poblados del Bronce de otras comarcas del País Valenciano y sobre todo de las más próximas, como el de Serra Grossa (Alicante), de donde procede un vaso igual al ovoide del Murón (fig. 6, a) y otras formas presentes en este y otros poblados de los aquí estudiados. Ya se citó también un caso de gran semejanza entre una vasija de Lloma Redona con otras de San Antón (Orihuela) y Cabezo Redondo (Villena), yacimiento donde tienen grandes paralelos los poblados del Valle Medio y en el cual se observan materiales propios del Bronce Valenciano, junto a otros del Argar B y del Bronce Tardío y Final enraizado en la Meseta, los cuales poseen ciertas similitudes con los que aquí se presentan. Algunos paralelos se observan también en varios poblados de L'Alcoiá, como el Mas de Menente o Taulallet (Alcoy) (L. PERICOT y F. PONSELL: 1928, fig. 8) y, en menor proporción, con otros poblados situados más al Norte.

A la vista de todo ello, creemos que el Valle Medio del Vinalopó estuvo incluido durante el Bronce Pleno en la cultura del Bronce Valenciano, aunque conservando cierta personalidad. El Alto Valle, concretamente la vega de Villena, debió estar inscrita al principio en la misma cultura, hasta que comenzaría a tener estrechos contactos con el Círculo Argárico durante el Argar B a través del pasillo de Jumilla-Yecla, los cuales van a provocar a mediados del $\mathrm{II}^{\circ}$ milenio a. C. cambios culturales en el Cabezo Redondo y en otros poblados de la zona que reciben fuertemente el impacto argárico. Pero, al mismo tiempo, se convierte en el centro de una importante encrucijada, al actuar seguramente como intermediario entre, al menos, tres ámbitos geográficos: el Segura, el Vinalopó y la Meseta (a través del pasillo de Caudete), de donde a fines del $\mathrm{II}^{\circ}$ milenio recibe el Cabezo Redondo importantes influencias reflejadas en las cerámicas incisas, acanaladas, impresas y excisas en los últimos momentos del poblado. A par- 
tir de ahí, el Cabezo Redondo pudo haber sido en la segunda mitad del II ${ }^{\circ}$ milenio un importante centro cuya influencia debió en parte recibirse en el Valle Medio del Vinalopó y probablemente también en otras zonas. Así, el Vinalopó sería una importante vía natural de comunicación entre la Meseta y la costa, por la cual descendieron seguramente a fines del $\mathrm{II}^{\circ}$ milenio las gentes del horizonte Cogotas I que ocuparon El Tabayá y el Castellar de Morera.

En el Valle Bajo, parece que los pocos poblados conocidos deben inscribirse en el Bronce Valenciano, aunque con notables influencias argáricas puestas de manifiesto, entre otras cosas, por el vaso polípodo carenado del Pic de les Moreres (Crevillente) (J. L. ROMAN LAJARIN: 1975, pp. 50-52), la copa de tipo argárico de la Serra del Buho (Elche) (J. L. ROMAN LAJARIN: 1980, p. 50) y la cista argárica procedente del mismo sitio y exhibida en el Museo de la Alcudia de Elche.

Por lo tanto, teniendo en cuenta que existen varios poblados encuadrables en el Círculo Argárico - aunque con cierta personalidad-en las estribaciones de las Sierras de La Pila y del Carche (Murcia), la frontera entre el Argar y el Bronce Valenciano debe extenderse por el Sistema Subbético, concretamente a lo largo de una vaga línea que, partiendo de algún punto impreciso en torno a Elche, enlazaría con las Sierras de Crevillente y Abanilla, siguiendo por las de La Algallat, Reclot y Salinas, donde, hasta mediados del $\mathrm{II}^{\circ}$ milenio a. C., la divisoria suponemos que se prolongaría hacia el Norte por la Sierra de la Lacera (aunque, por otro lado, pensamos que la parte NE de Murcia se incorporaría tarde a la Cultura Argárica). Ya en la segunda mitad del II ${ }^{\circ}$ milenio la vega de Villena - y quizá la de Elche- habrían entrado a formar parte de la Cultura Argárica, aunque sólo fuera marginalmente.

Si efectivamente ocurrió esto que proponemos, en estas dos zonas se truncaría la evolución cultural que parece producirse en el seno del Bronce Valenciano. En efecto, parece claro a estas alturas que el Bronce Valenciano no es un bloque monolítico geográficamente, admitiendo variantes comarcales o regionales, pero tampoco lo es a lo largo del tiempo, sino que se producen cambios sustanciales que justifican una periodificación. Un intento de la cual ha sido realizado por F. Gusi (F. GUSI: 1975), basándose en las fechas absolutas conocidas, pero a ello sólo podrá llegarse objetivamente mediante la obtención de secuencias estratigráficas claras.

Sin embargo, creemos que genéricamente puede hablarse de un Bronce Valenciano antiguo, centrado en la primera mitad del $\mathrm{II}^{\circ}$ milenio a. C., donde en las cerámicas privarían las formas simples y algunas carenas; habría poco metal, siendo comunes las puntas tipo Palmela; presencia de brazaletes de arquero, botones con perforación en $\mathrm{V}$; etc. Luego un Bronce Valenciano avanzado, que se situaría a mediados del $\mathrm{II}^{\circ}$ milenio, abarcando la mayor parte de la segunda mitad, época en la que las zonas limítrofes de la cultura entrarían en contacto con el Círculo Argárico, quizá con la Cultura de las Motillas y con el Bajo Aragón, acentuándose la diversidad comarcal dentro del Bronce Valenciano, seguramente por ser distintos sus contactos, entre otras razones. Los cambios en las formas materiales son más claros en la provincia de Castellón y Norte de la de Valencia, y en algunos de ellos quizá tengan mucho que ver con los contactos con el Bajo Aragón. Dichos cambios se manifiestan con la aparición de grandes tinajas con 
fondo plano o no, cuello muy exvasado y decoración en relieve; vasos troncocónico-invertidos con mamelones largos y cilíndricos que a veces aparecen con otras formas; vasos carenados de boca muy amplia y borde marcadamente exvasado; en general, más vasos con cuello, carenas más marcadas, fondos planos; puntas de flecha en metal con aletas y pedúnculo; mayor presencia de objetos de plata; etc., siendo particularmente abundantes los dos primeros elementos en el Norte del País.

En tercer lugar, un Bronce.Valenciano tardío, evidente por lo menos en amplias zonas, que se iniciaría a fines de $\mathrm{II}^{\circ}$ milenio (¿siglo XIII?) y en el cual se intensificarían los contactos exteriores, sobre todo con la Meseta, pero también con el Ebro y quizá con Cataluña. Se caracterizaría por la presencia de algunos elementos materiales propios del Bronce Final, pero dominando aún las formas propias del Bronce Valenciano. La arribada masiva de tales elementos justificaría ya la presencia de un Bronce Final, cuyas raíces son ajenas al País Valenciano.

A la vista de los materiales conservados, parece que la segunda fase fue el momento álgido de poblamiento del Valle Medio del Vinalopó y probablemente también para el Valle Alto. Aunque, indudablemente, esta y otras hipótesis aquí vertidas deberán comprobarse con investigaciones futuras o las ya en curso.

Ya en prensa este artículo hemos tenido ocasión de conocer otro de M. Gil Mascarell («Bronce Tardío y Bronce Final». El Bronce Final y el comienzo de la Edad del Hierro en el País Valenciano, Monografías del Laboratorio de Arqueología de Valencia, 1, Valencia, 1981, pp. 9-38) donde se publica un interesante conjunto de materiales. Estos y las opinión de la autora sobre el Bronce Tardío y Final son de indudable valor para comprender el significado de la Edad del Bronce en el Valle Medio del Vinalopó, al tiempo que se abren nuevas perspectivas cronológicas y de relaciones comarcales.

\section{BIBLIOGRAFIA}

CENTRO EXCURSIONISTA ELDENSE: 1972. «Carta arqueológica del Valle de EIda». Archivo de Prehistoria Levantina, XIII, Valencia, pp. 199-208.

FURGUS, J.: 1937. Collecció de treballs sobre prehistoria valenciana. "Trabajos Varios del SIP.», 5, Valencia.

GOMEZ GARCIA, V.: 1976. Informe del profesor jefe de los Grupos de Operación Rescate núms. 688 y 689 (Colegio Padre Dehón, PP. Reparadores, de Novelda). Novelda (20-V-76) (inédito).

GRUPO DE RESCATE N. ${ }^{\circ} 688$ (COLEGIO PADRE DEHON, NOVELDA): 1978. «Mapa arqueológico de Novelda». «Revista del Instituto de Estudios Alicantinos», 23, Alicante, pp. 59-66.

GUSSI JENER, F.: 1975. «Las dataciones de C-14 de la çueva del Mas d'Abad (Coves de Vinromá). Campaña 1975. Ensayo cronológico para la periodificación del Bronce Valenciano». Cuadernos de Prehistoria y Arqueología Castellonense, 2, Castellón de la Plana, pp. 75-79.

HERNANDEZ PEREZ, M. S.: 1980. Excavaciones arqueológicas en La Horna (Aspe, Alicante). $1 .{ }^{a}$ campaña. Informe provisional (inédito).

JIMENEZ DE CISNEROS, D.: 1925. «Indicación de algunos yacimientos prehistóricos y noticia acerca de otros». Boletín de la Real Sociedad Española de Historia Natural, XXV, Madrid, pp. 71 81. 
LLOBREGAT CONESA, E.: 1966. «Avance a una clasificación tipológica de las cerámicas del Bronce Valenciano: la colección del Museo Arqueológico Provincial de Alicante». IX Congreso Nacional de Arqueología (Valladolid, 1965), Zaragoza, pp. 129-134.

NAVARRO CASTELLO, R.: 1978. El Vinalopó y su importancia arqueológica. Novelda.

PERICOT, L., y F. PONSELL: 1928. «El poblado de «Mas de Menente» (Alcoy)». Archivo de Prehistoria Levantina, I, Valencia, pp. 101-112.

ROMAN LAJARIN, J. L.: 1975. «Un yacimiento de la Edad del Bronce en el «Pic de les Moreres» (Crevillente, Alicante)». Arch. Preh. Lev., XIV, Valencia, pp. 47-64.

- 1978. «Materiales arqueológicos del «Puntal del Buho» (Elche, Alicante) ». Rev. Inst. Est. Alic., 24, Alicante, pp. 7-25.

- 1980. «Los yacimientos de la Edad del Bronce de la «Serra del Buho». Festa d’Elig, 80, Elche, pp. 39-56.

TARRADELL MATEU, M.: 1963. «Ensayo de identificación de la necrópolis del Bronce Valenciano». Arch. Preh. Lev., X, Valencia, pp. 59-67. 

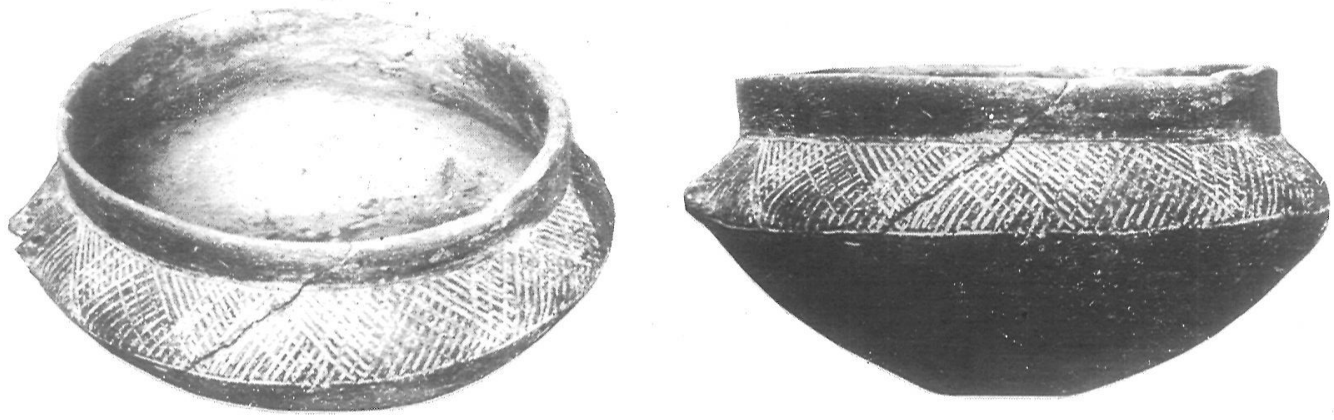

a

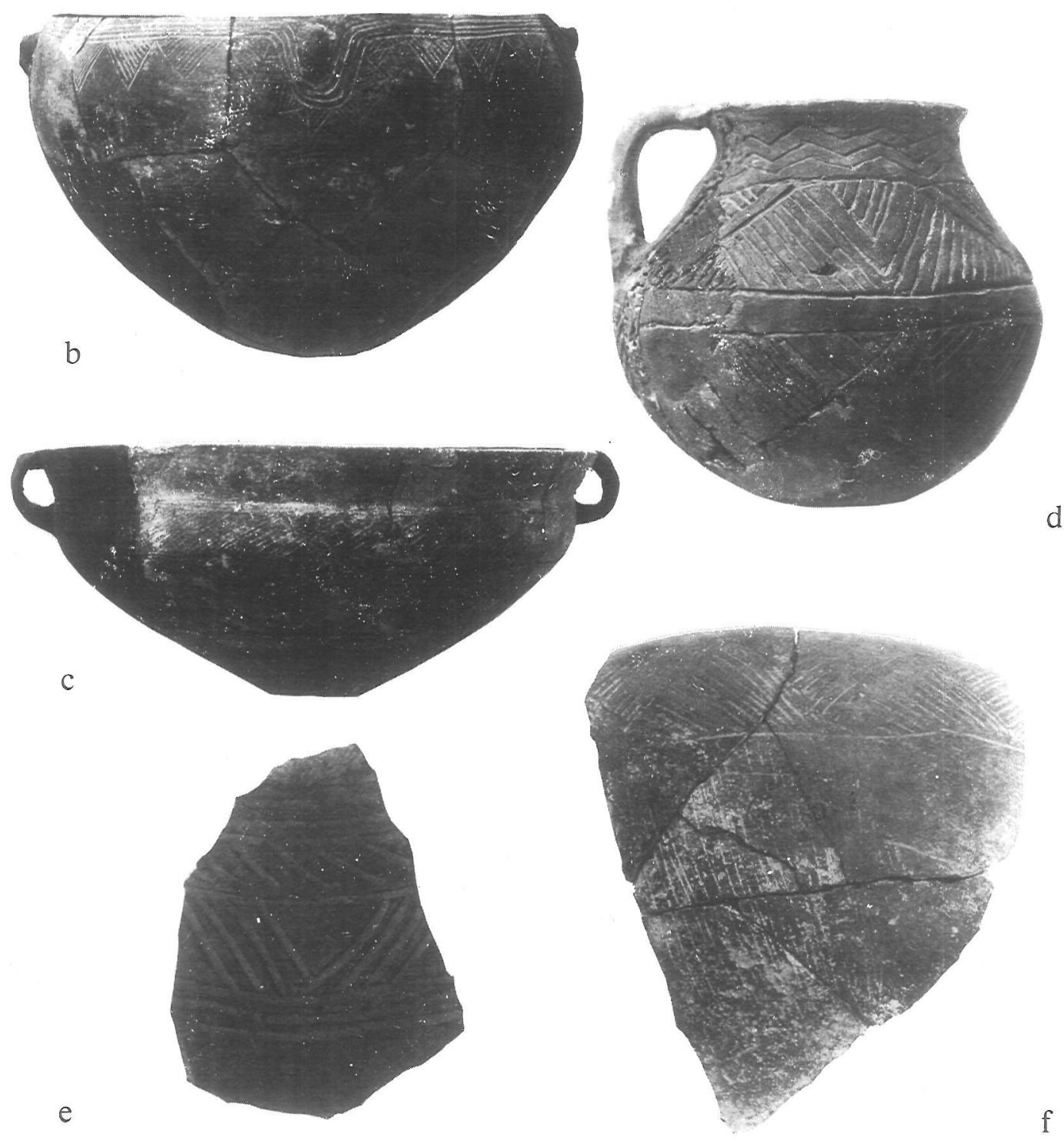

I. El Tabayá (Aspe) 

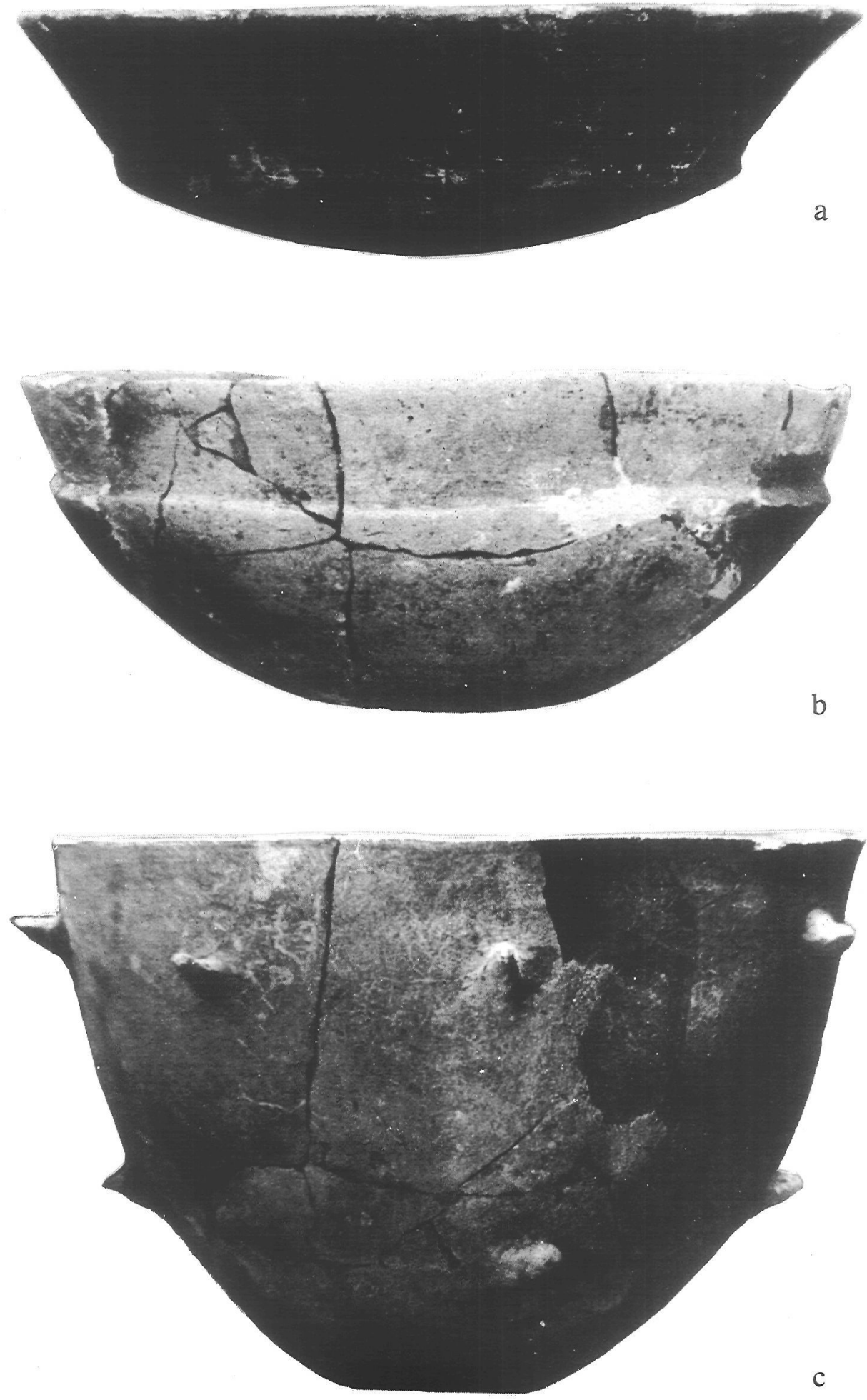

II. El Tabayá (Aspe) (a y b). El Murón (Aspe) (c). Las tres vasijas tienen claros paralelos en el Cabezo Redondo (Villena). 


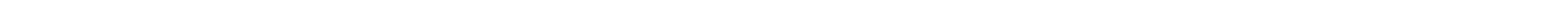

